UNIVERSIDADE DE SÃO PAULO

FACULDADE DE FILOSOFIA, LETRAS E CIÊNCIAS HUMANAS

DEPARTAMENTO DE LETRAS CLÁSSICAS E VERNÁCULAS

PROGRAMA DE PÓS-GRADUAÇÃO EM FILOLOGIA E LÍNGUA PORTUGUESA

\title{
A ordem de constituintes sentenciais no português paulista
}

Priscilla Barbosa Ribeiro 
UNIVERSIDADE DE SÃO PAULO

FACULDADE DE FILOSOFIA, LETRAS E CIÊNCIAS HUMANAS

DEPARTAMENTO DE LETRAS CLÁSSICAS E VERNÁCULAS

PROGRAMA DE PÓS-GRADUAÇÃO EM FILOLOGIA E LÍNGUA PORTUGUESA

\title{
A ordem de constituintes sentenciais no português paulista
}

Priscilla Barbosa Ribeiro

\begin{abstract}
Dissertação apresentada ao Programa de Pós-Graduação em Filologia e Língua Portuguesa do Departamento de Letras Clássicas e Vernáculas da Faculdade de Filosofia, Letras e Ciências Humanas da Universidade de São Paulo, para a obtenção do título de Mestre em Letras
\end{abstract}

Orientadora: Profa. Dra. Marilza de Oliveira 


\section{Agradecimentos}

A Deus, pelo dom da vida, por me sustentar e guiar em todos os momentos, e pelas inúmeras bênçãos que me tem proporcionado.

À professora Marilza, por sua dedicação e envolvimento em cada passo da pesquisa, mostrando sempre criatividade e empolgação contagiante. Por orientar com alegria e seriedade, me socorrer com a maior boa vontade nas horas mais desesperadas, e ser muito mais do que competente no que faz. Obrigada por tudo.

À equipe do Acervo da Escola Caetano de Campos, em especial a Fabiana Valeck de Oliveira e Cristiane da Silva Braga, pelo auxílio fundamental prestado durante o longo período de consulta aos documentos.

À direção e aos funcionários do Arquivo do Estado de São Paulo, em particular ao Tárcio, pelo auxílio prestado com seriedade, competência e solicitude.

À Secretaria de Pós-Graduação do DLCV pelo suporte nos últimos dois anos, em especial à Dayane Esteves, por sua extrema competência e boa vontade.

À Beth Pujol (in memorian), por ceder gentilmente o Relatório dos Negócios do Interior e da Instrução Pública apresentado ao Governo do Estado de São Paulo pelo secretário Alfredo Pujol no ano de 1896.

Às professoras Flaviane Fernandes e Lilia Schwarcz pelas preciosas sugestões no exame de qualificação. À prof Lilia agradeço também pelo fantástico curso "Uma história da antropologia brasileira", que levou a leituras e reflexões essenciais para o desenvolvimento da pesquisa e para minha formação.

Aos Profs. Drs. Carlos Bacellar e Maria Aparecida Lopes Rossi, por gentilmente aceitarem o convite para a banca de defesa mesmo sendo época de férias da universidade.

Ao meu querido amigo Paulo Roberto Gonçalves Segundo, primeira pessoa a me incentivar - e muito! - a investir na pesquisa acadêmica. Sua companhia tornou os anos de graduação muito mais agradáveis, obrigada por sua amizade preciosa. 
Às colegas de trabalho do Projeto Caipira e amigas Giovanna Ike Coan, Hosana dos Santos Silva e Érica Bertolon.

À Gi, pela ajuda no final do trabalho e pela versão em inglês do resumo. Companheira de cursos, congressos, trabalhos e passeios, obrigada por tudo.

À Hosana, pela leitura do texto da qualificação e de parte da versão final. Por sua crítica firme, inteligente e construtiva. Por aconselhar com amor e sabedoria.

À Érica, pelo carinho e amizade sincera, e por ser uma grande incentivadora. Seu entusiasmo e encantamento me inspiram.

Aos meus pais, Mariza e Darcílio, pelo amor, suporte e incentivo, não apenas durante o mestrado, mas sempre. Agradeço também por aguentarem junto comigo a tensão no final do trabalho - e principalmente por me aguentarem nesse período...

À minha irmã Erika e meu sobrinho Matheus, que apesar da distância estão sempre presentes, encorajando e procurando ver o lado positivo em qualquer situação.

À minha prima Luciene e à Meire, pela compreensão e incentivo.

Aos meus tios e tias tão queridos, que torcem por mim e sempre comemoraram cada pequena vitória. Obrigada por seu estímulo.

Ao meu namorado Marcos Custódio, por seu apoio, carinho, alegria, incentivo e compreensão, especialmente nas últimas semanas. Obrigada por fazer parte da minha vida.

À FAPESP, pela bolsa de mestrado que muito auxiliou o desenvolvimento desta pesquisa. 
De fato, ele estava escrevendo ou mais particularmente: traduzia para o "clássico" um grande artigo sobre "Ferimentos por arma de fogo". O seu último truc intelectual era este do clássico. Buscava nisto uma distinção, uma separação intelectual desses meninos por aí que escrevem contos e romances nos jornais. Ele, um sábio, e sobretudo, um doutor, não podia escrever da mesma forma que eles. A sua sabedoria superior e o seu título "acadêmico" não podiam usar da mesma língua, dos mesmos modismos, da mesma sintaxe que esses poetastros e literatecos. Veio-lhe então a idéia do clássico. O processo era simples: escrevia do modo comum, com as palavras e o jeito de hoje, em seguida invertia as orações, picava o período com vírgulas e substituía incomodar por molestar, ao redor por derredor, isto por esto, quão grande ou tão grande por quamanho, sarapintava tudo de ao invés, em-pós, e assim obtinha o seu estilo clássico que começava a causar admiração aos seus pares e ao público em geral.

Lima Barreto. Triste fim de Policarpo Quaresma, 1915 


\section{A ordem de constituintes sentenciais no português paulista}

A ordem de constituintes sentenciais é um tema que já foi abordado em muitos estudos e ainda gera interesse entre os linguistas. Os trabalhos diacrônicos sobre o assunto apontam que, ao longo da história do Português Brasileiro (PB), a ordem SV (sujeito-verbo) tem sido privilegiada em contraposição à sequência VS (verbo-sujeito), mais usual em estágios anteriores da língua (cf. Berlinck: 1989, Duarte: 1992, Torres Morais: 1993, e outros). Fixando o olhar no final do século XIX, analisamos a posição do sujeito em relação ao verbo em textos da Escola Normal da Capital (ENC), comparando-os com textos de escritores brasileiros e portugueses, com vistas a identificar um modelo linguístico referencial para a instituição. O corpus da pesquisa foi constituído a partir de cartas e atas produzidas por professores e diretores da ENC, homens públicos de prestígio na época, o que caracteriza esse material como sendo a expressão de um padrão linguístico culto. Visando a analisar o fenômeno linguístico inserido em seu contexto de produção, fizemos o levantamento e caracterização de aspectos da cidade e da instituição escolar (como o corpo de diretores, docentes e discentes, e o currículo escolar, em particular da língua portuguesa), buscando, deste modo, realizar uma análise complementarmente histórica, social, cultural e linguística.

Palavras-chave: ordem de constituintes, posição do sujeito, Escola Normal, habitus linguístico, História Social da Língua 


\section{Word order in Brazilian Paulista Portuguese}

Word order has been the theme of many researches, but it still intrigues linguists. Diachronic studies have shown that in the history of Brazilian Portuguese (BP) the order SV (subject-verb) has been used in preference to the sequence VS (verb-subject), which was more common in earlier stages of the language (cf. Berlinck: 1989, Duarte: 1992, Torres Morais: 1993, among others). Focusing on the phenomenon of word order at the end of the $19^{\text {th }}$ century, we analyze the subject position in relation to the verb in texts from the Escola Normal da Capital (São Paulo Normal School - ENC) and compare the data with texts produced by Brazilian and Portuguese writers, with the intention of identifying a linguistic referential model for the educational institution. The research corpus is composed of letters and minutes written by the teachers and principals of the ENC, prestigious public men at that time; hence this material can be taken as the expression of a standard linguistic variety. Aiming at analyzing the linguistic phenomenon within its production context, we did a survey and a characterization of aspects of the city and the institution (such as the board of principals and teachers and the student body, as well as the school curriculum, especially the Portuguese syllabus), with the purpose of conducting an analysis that is historical, social, cultural and linguistic altogether.

Keywords: word order, subject position, Normal School, linguistic habitus, Social History of Language 


\section{Sumário}

Introdução.

Capítulo 1: A Escola Normal da Capital no contexto da virada do século. 06

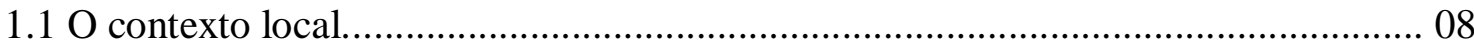

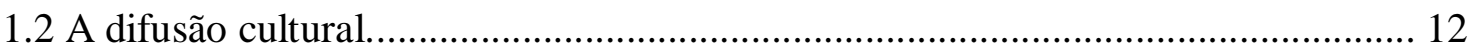

1.2.1 O ensino público e a Escola Normal da Capital................................................. 13

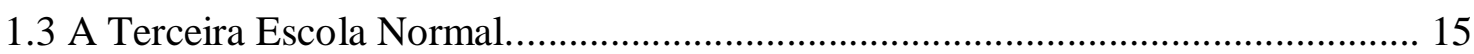

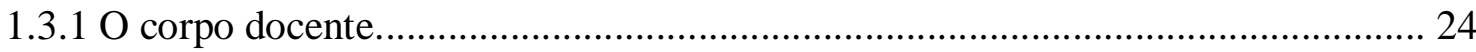

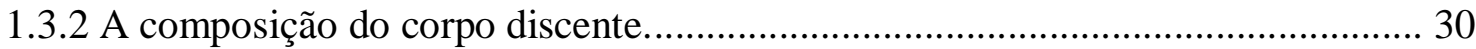

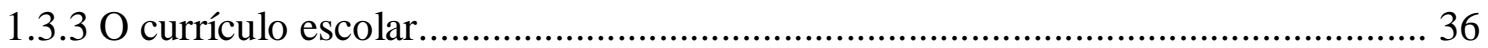

1.3.3.1 O espaço da Língua Portuguesa no currículo da ENC....................................... 38

1.4 A 'missão' da Escola Normal da Capital: os trilhos do progresso e a ferrugem nas

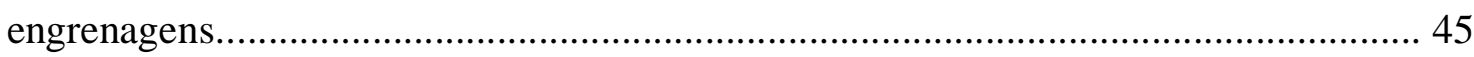

1.5 Ordem de constituintes e estilo: a questão da inversão......................................... 46

1.5.1 A ordem em foco: o olhar dos (e sobre os) gramáticos..................................... 47

1.5.2 A ordem de constituintes no currículo escolar................................................. 49

Capítulo 2: A posição do sujeito: colocando a questão nos trilhos......................... 52

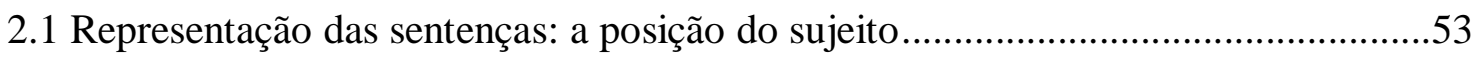

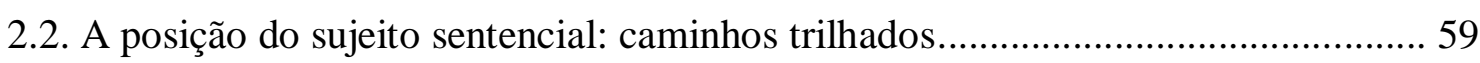

2.2.1 Juízos tético e categórico: a posição do sujeito...................................................64

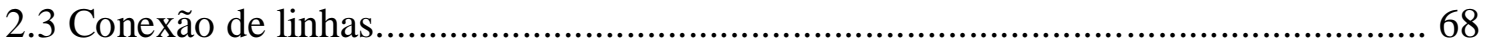

Capítulo 3: A Posição do Sujeito Sentencial: ramificação dos trilhos .................... 70

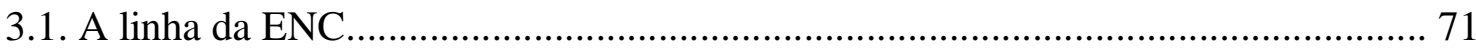

3.2. Possíveis fatores condicionantes................................................................. 72

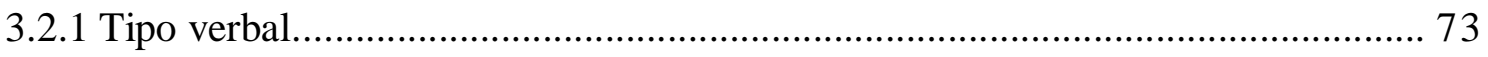

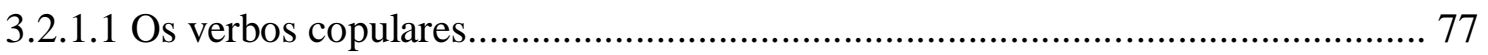




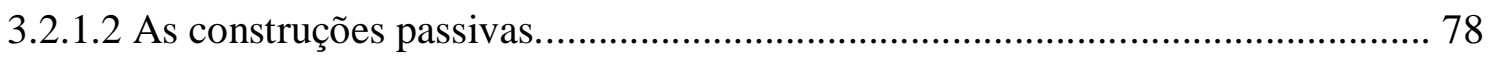

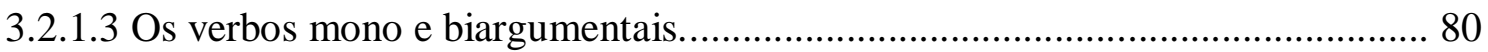

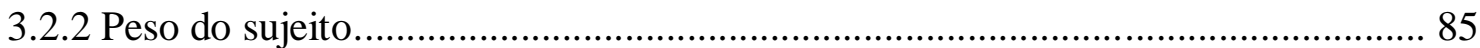

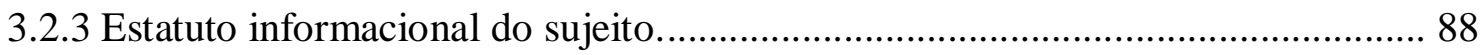

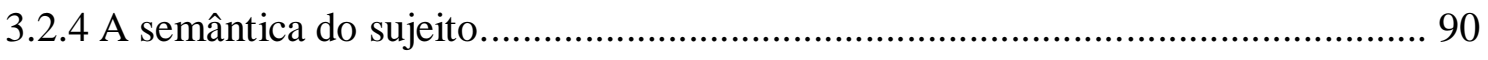

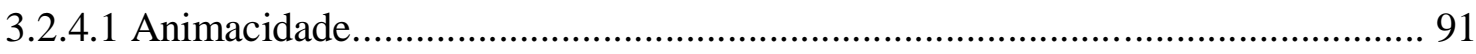

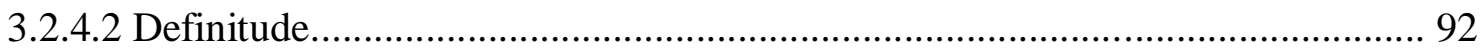

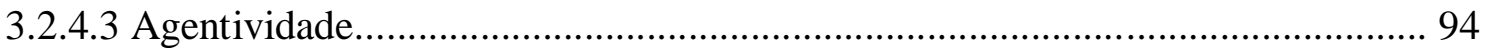

3.2.5 A ordem e a codificação de juízos tético e categórico............................................ 96

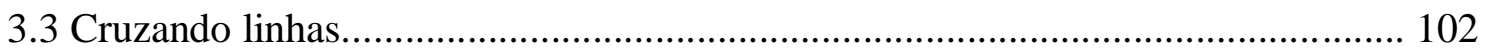

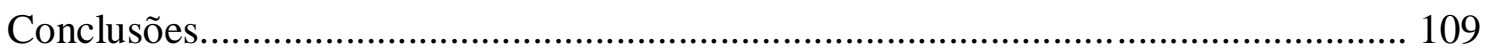

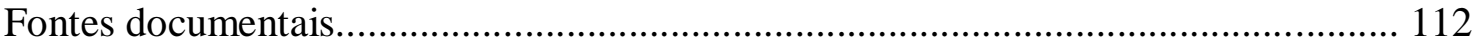

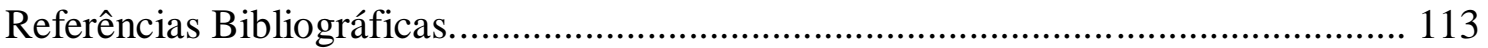




\section{LISTA DE ABREVIAÇÕES}

\section{Capítulo 1}

ADSP - Academia de Direito de São Paulo

ENC - Escola Normal da Capital

PB - Português Brasileiro

PE - Português Europeu

SV - Sujeito-Verbo

VS - Verbo-Sujeito

\section{Capítulo 2}

COMP - Complemento

$\mathrm{CP}$ - Complementizer Phrase

IP - Inflection Phrase

SN - Sintagma Nominal

SPEC - Especificador

VP - Verbal Phrase 


\section{Introdução}

O artifício linguístico retratado no romance Triste Fim de Policarpo Quaresma (1915), em trecho reproduzido na epígrafe deste estudo, mostra como a língua pode ser um importante elemento de distinção social. O uso da linguagem pela personagem Dr. Armando Borges serviu como forma de ascensão profissional e, consequentemente, social, de um médico sem grandes méritos intelectuais e culturais, mas que, por meio do uso consciente da língua, distinguia-se, alcançando postos hierárquicos cada vez mais elevados. Para isso, diferenciava-se não somente por utilizar um vocabulário mais requintado, mas também por uma sintaxe diferenciada, com orações invertidas, entre outras características. A crítica do autor inserida no romance fornece uma pista de que a ordem era, no início do século XX, uma questão polêmica. Este fato, observado por $\operatorname{literatos}^{1}$, não se restringia à ordem das orações, como aponta Lima Barreto, mas se refere também à ordem de constituintes sentenciais, que pretendemos discutir neste trabalho.

O período a que remete este estudo, o final do século XIX, foi um momento crucial na formação do que hoje se denomina Português Brasileiro (PB). Nesse período se fortaleceu um sistema gramatical novo em relação à língua do Brasil colônia, trazida pelos portugueses (Tarallo, 1993), a partir do qual vários aspectos linguísticos se modificaram, inclusive a ordem de constituintes sentenciais ${ }^{2}$. Estudos diacrônicos mostram que, entre os séculos XVIII e XX, a ordem Verbo-Sujeito (VS) passou a ser menos produtiva e restrita a contextos linguísticos específicos. Em contrapartida, o uso

\footnotetext{
${ }^{1}$ O escritor José Veríssimo discute a mesma questão, conforme registramos no Capítulo 1, seção 4 desta dissertação.

${ }^{2}$ A questão se refere à colocação dos elementos Sujeito, Verbo e Complemento na sentença.
} 
de sequências Sujeito-Verbo (SV) tornou-se preferencial, sendo a ordem característica do PB atual.

Esse quadro foi traçado a partir de textos informais ou de reprodução de fala, como cartas pessoais e peças de teatro, visando ao espelhamento, ainda que em certa medida, do uso vernáculo da língua. Nosso trabalho, contudo, segue por outra via. Além de não adotar a perspectiva diacrônica, isto é, não se trata de um trabalho sobre mudança linguística, optamos por trabalhar com um material formal produzido em ambiente escolar. Mais do que isso: produzido em uma escola normal por aqueles que estavam à frente da direção do ensino e da instituição, como seus professores e diretor. Portanto, há que se observar que, apesar de tomar estudos sobre o PB como parâmetro de comparação, realizamos nesta pesquisa um recorte que compreende a língua de São Paulo, especificamente em uso formal e no âmbito da Escola Normal da Capital (ENC), primeira escola normal de São Paulo.

Considerando esse contexto de mudança linguística em relação ao vernáculo e o caráter formal e escrito do corpus da análise, surge a questão de qual seria o paradigma linguístico utilizado na ENC. Teria a modalidade escrita culta, formal, se influenciado pelas inovações do vernáculo, que tendia à intensificação de uso de sequências SV (Berlinck, 1989; Torres Morais, 1993), ou conservava ela a ordem VS?

O distanciamento entre língua falada e escrita já foi demonstrado por estudos que apontam nesta última a tendência ao conservadorismo ${ }^{3}$ (Kato 1996, 1999). O caráter conservador de outros objetos linguísticos na escrita culta foi justificado com base no espelhamento no Português Europeu (PE) moderno, estratégia de distanciamento da elite em relação às classes populares (Pagotto, 1998). No entanto, seria o PE, em período republicano, modelo linguístico para o paulista culto, considerando que o Brasil

\footnotetext{
${ }^{3}$ A autora ressalta que a escrita tende a manter certos aspectos da língua em termos quantitativos, mas a análise qualitativa dos dados mostra não se tratar do uso de elementos adquiridos naturalmente.
} 
já era há muito independente, e com o fim da Monarquia distanciava-se ainda mais de Portugal $^{4}$ ? Para responder a essa questão, estudaremos a ordem de constituintes no PE do século XIX nas cartas de escritores portugueses.

Paralelamente, serão estudados textos de escritores brasileiros e de dois membros da intelectualidade paulista Eduardo da Silva Prado, ligado à aristocracia cafeeira, e Luis Pereira Barreto, representante da elite emergente ${ }^{5}$. Afinal, é de se supor que a Escola Normal paulista buscasse um modelo em seu próprio território, valorizando a língua local, especialmente por ser um momento em que o Brasil começava a se definir como nação e São Paulo ganhava destaque no cenário nacional.

A análise da posição do sujeito nos textos produzidos no âmbito da ENC tem sua amostra composta por 124 cartas da Correspondência Oficial da Escola Normal, de 1894, e 19 Atas da Congregação, de 1895, produzidas pelo Diretor da ENC e professores nas funções de diretor interino ou secretário. Trata-se de textos com a finalidade de registro e organização internos da instituição.

As cartas da Correspondência Oficial de 1894 são, quase na totalidade, destinadas ao 'Secretario do Estado dos Negocios do Interior' ou então ao 'Diretor do Thesouro do Estado’ - à época, o Dr. Cesário Motta Junior e o Coronel Pedro Gonçalves Dente, respectivamente. Têm como objetivo principal fazer solicitações ao Governo, bem como informar sobre decisões relativas a atividades da Escola. Algumas raras exceções para outros destinatários, como o Instituto Histórico e Geográfico, têm por finalidade o agradecimento por doações e/ou solicitação, entre outros. As atas, por sua

\footnotetext{
${ }^{4}$ A Independência do Brasil foi o primeiro passo para o afastamento da até então metrópole Portugal. Contudo, o fato do príncipe D. Pedro proclamar a independência e em seguida assumir a direção política do país matizou a relevância dessa 'separação'. Com a proclamação da República a mudança se torna mais representativa, posto que o dirigente da nação já não era membro da família real.

${ }^{5}$ É impreciso caracterizar a sociedade da época como sendo constituída de 'elite' e 'não elite'. No interior desses grupos há subdivisões importantes, como a que distingue as famílias aristocráticas das que possuíam certo poder econômico, mas não tinham linhagem tradicional (Comunicação do Prof. Dr. Carlos de A. P. Bacellar na qualificação de doutorado em Língua Portuguesa de Hélcius Batista Pereira (FFLCH/USP, dez./ 2008)).
} 
vez, registram os conteúdos das reuniões da Congregação, incluindo as decisões tomadas nesses encontros, os assuntos discutidos, e até mesmo relatando os atritos nelas ocorridos.

O material analisado foi gerado numa instituição que deveria ser a principal responsável por prover docentes para os grupos escolares que eram então criados na capital e no interior da Província (posteriormente, Estado). Por se tratar de um ambiente de ensino, suas atividades e produções deveriam refletir aspectos dos processos de aprendizagem que ela promove, os quais marcam a diferença entre os jovens ingressantes e formandos da instituição.

Nesse sentido, a escola usualmente atua no campo linguístico de modo a incentivar o emprego de determinadas formas e cercear o de outras, especialmente no que se refere a inovações (Kato, 1999). Diferentemente da fala, a escrita se caracteriza por processos mais conscientes, o que se intensifica no caso de uma escrita mais elaborada. Enquanto a primeira é um fenômeno natural, biológico, a escrita é um fenômeno cultural (Lenneberg, 1964 apud Kato, 1999) ligado à díade ensinoaprendizagem. Isso significa que a modalidade escrita não é plenamente produto de aquisição linguística, processo natural e biológico que dispensa o ensino formal, mas reflete a aprendizagem, resultante da instrução promovida por escolas e outras instituições culturais (Kato, 1999) ${ }^{6}$.

Considerando tal proposição, entendemos que para desenvolver uma análise adequada não poderíamos focar unicamente o dado linguístico sem considerar os elementos externos relacionados à sua produção. Assim, nos voltamos também para a história da ENC no contexto de inovações estruturais e sociais da cidade de São Paulo.

\footnotetext{
${ }^{6}$ Não queremos, com isso, dizer que a fala seja inconsciente e sem planejamento - há, inclusive, situações em que ela pode apresentar um alto grau de elaboração, como em palestras, discursos, etc. Por meio da oposição fala-escrita, pretendemos enfatizar o caráter consciente da escrita, que, diferentemente da fala, precisa ser ensinada e aceita correções e reformulações que o texto falado não permite.
} 
A chegada da 'modernidade' representada pela luz elétrica e pelos bondes, o grande afluxo de imigrantes, o surgimento de instituições intelectuais diversas são somente alguns entre muitos fatos que marcaram - e promoveram - a urbanização da cidade.

Nesse momento, as formas de distinção social se manifestavam nos mais diversos aspectos, desde o vestuário, a arquitetura das casas, o gosto artístico e, entre outros fatores, o(s) uso(s) da língua. Dadas estas importantes correlações, desenvolvemos este estudo no âmbito da História Social da Língua tencionando identificar, além das formas de realização da ordem, resultados acerca do ambiente de produção de um modo geral, uma vez que a língua, particularmente em sua modalidade escrita, tende a refletir filiações e escolhas culturais.

Em suma, pretendemos, neste estudo, descrever o uso da ordem de constituintes sentenciais na Escola Normal tendo em vista sua correlação com elementos sociais, históricos e culturais. Analisando o objeto não apenas de um ponto de vista estritamente linguístico, buscamos apoio na perspectiva sociológica de Pierre Bourdieu. No Capítulo 1 da dissertação, fundamentadas nos conceitos desse autor, procedemos ao levantamento de aspectos da ENC tais como sua história, seus dirigentes, professores, alunos e currículo, buscando verificar como cada um desses elementos contribuía para a caracterização da instituição. Ademais, realizamos o levantamento das perspectivas dos usos da ordem entre os letrados da época, como gramáticos e literatos. No Capítulo 2 constam a exposição dos pressupostos teóricos e a revisão bibliográfica sobre a ordem de constituintes. Por fim, no Capítulo 3, apresentamos a análise do corpus, a partir da qual esboçamos as Conclusões, derivadas de uma interpretação não somente linguística, mas também sócio-histórica a respeito da ordem de constituintes no português paulista culto - ou de um recorte deste - no século XIX. 


\section{Capítulo 1}

\section{A Escola Normal da Capital no contexto da virada do século}

O final do século XIX, período da história do Brasil em que se situa o presente estudo, é bastante complexo de diversos pontos de vista político (social, cultural, etc.). Nele ocorreram inúmeras transformações nos mais diversos âmbitos, dentre as quais destacaremos as que se mostrarem mais relevantes para a contextualização do objeto deste estudo. Para tanto, enfocaremos aspectos da história da cidade de São Paulo, da história da educação e, finalmente, abordaremos a história da Escola Normal da Capital (ENC), enfocando sua terceira fase, iniciada com a inauguração de $1880^{7}$.

Inseridas em um quadro social altamente heterogêneo, a cultura, língua, política - em suma, aspectos identitários nacionais e, em particular, paulistas - se reformulavam. No conjunto dessas inovações insere-se a Escola Normal, que se realocou na cidade para novos bairro e edifício, e se reestruturando internamente, movimentos desencadeados a partir da assunção dos republicanos ao poder.

Tendo em vista a importância do contexto de produção dos materiais analisados neste estudo, buscamos desenvolvê-lo dentro de uma perspectiva que concilia o individual e o social, segunda a proposta sociológica de Pierre Bourdieu. Aplicada pelo autor, entre outros, ao campo linguístico, pretendemos utilizá-la visto que produções individuais como as que analisamos, apesar de suas idiossincrasias, estão inseridas no conjunto de possibilidades de produção de determinados grupos, o que, de certo modo, reflete seus valores, relações, e pretensões.

Essa perspectiva se baseia na conciliação desses dois planos - individual e social - no conceito bourdiesiano de habitus, "sistema de disposições socialmente constituídas

\footnotetext{
${ }^{7}$ A Escola já havia funcionado anteriormente em duas épocas: de 1846 a 1867, e de 1875 a 1878.
} 
que, enquanto estruturas estruturadas e estruturantes, constituem o princípio gerador e unificador do conjunto das práticas e das ideologias características de um grupo de agentes"8 (Bourdieu, 2009:191).

Esse sistema de disposições se constitui a partir de elementos exteriores ao indivíduo, ao mesmo tempo alicerçados no convívio social e desencadeados por ele. Entre os ambientes em que se manifesta, destaca-se a família, primeiro núcleo responsável pela formação de habitus com o qual o sujeito tem contato. Sua assimilação se dá na geração de sistematizações no âmbito das práticas e das ideias, transformadas em um sistema de disposições duradouras. São condicionamentos individuais que têm sua origem no meio social.

O habitus se fundamenta na relação entre indivíduo e sociedade na medida em que, ao mesmo tempo, é socialmente definido e define o indivíduo em uma sociedade heterogênea. Ele se constrói e se revela nas práticas sociais, como na manifestação do gosto, refletindo valores adquiridos no processo de socialização. Nesse sentido, o indivíduo está exposto a um conjunto limitado de opções disponíveis no ambiente em que se insere, de forma que a variação das escolhas por ele realizadas acaba por ser também limitada.

Deste modo, antes de ser o resultado da obediência a regras ou imposições, o habitus aproxima-se mais da assimilação de tendências sócio-culturalmente determinadas, que vão caracterizar e identificar sujeitos com grupos específicos, ao mesmo tempo produzindo e unificando práticas em um determinado espaço social. Assim como este não é estático, mas sujeito a transformações, o habitus acompanha os movimentos do espaço social do qual é, ao mesmo tempo, produto e produtor.

\footnotetext{
${ }^{8}$ A proposta sociológica de Bourdieu se fundamenta em conceitos intrinsecamente relacionados, alguns dos quais exporemos nesta seção, dando, porém, enfoque à noção de habitus, que nos servirá de suporte na análise.
} 
O campo define-se por apresentar distinções hierárquicas e uma lógica específica de funcionamento, tendo como fundamento diferentes tipos de capital que estruturam a sociedade hierarquizada. O (i) capital econômico, referente aos bens de produção e patrimônio; o (ii) capital cultural, relacionado à formação intelectual e representado em habilidades adquiridas, títulos escolares e bens materiais (quadros, livros, etc.); o (iii) capital social é representado pelo conjunto de relações sociais do indivíduo, que pode contribuir para uma mudança social almejada ou dificultá-la; e, por fim, há também o (iv) capital simbólico, conjunto de ações que identificam lugar social de prestígio (como as boas maneiras) (Bonnewitz, 2003:53-54).

Esses capitais diversos participam de um mercado que não é apenas econômico, mas que se estabelece socialmente em redes abstratas de relações. Nele, as noções de habitus, campo e capital encontram-se intrinsecamente relacionadas. Desse conjunto, destacaremos o conceito de habitus aplicado em particular ao campo linguístico, visando a depreender as relações e valores sócio-culturais que estão por trás das produções linguísticas analisadas nesta pesquisa. Como fundamentação para o estudo, delinearemos os contextos social e da instituição escolar, para podermos proceder com mais propriedade a uma análise de textos de um padrão culto de língua - o da ENC que seja complementarmente linguística e sócio-histórica.

\section{$1.1 O$ contexto local}

Em fins do XIX, a província de São Paulo engatilhou um intenso desenvolvimento e passou a ganhar expressividade em âmbito nacional. O cenário em que se deu esse processo começou a se compor de modo mais marcante a partir da 
segunda metade do século XIX. Até então, a região apresentava pouca relevância política, o que se alterou com o estabelecimento do regime republicano, e passou a assumir também maior destaque econômico, devido à valorização do café no mercado internacional ${ }^{9}$.

A ascensão econômica da província e o advento da abolição da escravidão acarretaram um intenso fluxo migratório, tanto de contingentes nacionais como de estrangeiros. Além da necessidade de mão de obra trabalhadora para assumir as funções dos ex-escravos, então libertos, a florescente e promissora prosperidade econômica atraiu homens de negócios e empresas estrangeiras (Cantuaria, 2004:43), aos quais se assomou uma população ligada à cafeicultura, vinda do interior do Estado. Nesse momento, acompanhando o surgimento de várias instituições intelectuais ${ }^{10}$, surgem também elites econômicas e culturais que ganhavam espaço e autonomia.

O espaço da cidade passava então a ser ocupado de modo a produzir - e reproduzir - as distinções de âmbito sócio-econômico e cultural. A elite da terra, conforme aponta a literatura (Pires, 2006; Homem, 1996), ocupou inicialmente a região hoje conhecida como 'centro velho'. No triângulo formado pelas ruas São Bento, 15 de Novembro e Direita se fixaram os grandes cafeicultores vindos do interior, os chamados barões do café ${ }^{11}$. Essa área foi sendo deixada pelas gerações seguintes, que buscavam distanciar-se do comércio da região do triângulo, que então se intensificava. Essa população, que se deslocava para áreas como Santa Ifigênia, Campos Elíseos e Higienópolis, consistia na classe alta da sociedade paulistana da época, representada pelas famílias Silva Prado, Álvares Penteado, Paes de Barros, Monteiro de Barros,

\footnotetext{
${ }^{9}$ No século XVIII, a província de São Paulo não tinha projeção política nacional. Contudo, já se apresentava economicamente representativa devido ao açúcar. A prosperidade trazida pela produção de café veio fortalecer ainda mais essa condição.

${ }^{10}$ Em 1894 foram criados o Instituto Histórico e Geográfico de São Paulo, a Escola Politécnica, a Sociedade de Medicina e Cirurgia de São Paulo, e em 1895, o Museu Paulista. O Instituto Butantã e a Escola Livre de Farmácia datam de 1899 (Costa \& Schwarcz, 2007: 32-33).

${ }^{11}$ Em um primeiro momento, esse espaço foi ocupado por sujeitos ligados ao açúcar e por grandes comerciantes (Prof. Dr. Carlos Bacellar (comunicação pessoal)).
} 
Souza Queiroz, entre outras (Homem, 1996: 123). No entanto, a classe alta compunhase também de estrangeiros, como os Matarazzo, Crespi, Siciliano, Jafet, etc., que residiam principalmente na avenida Paulista e região da Bela Vista.

Com potencial econômico e social para inserir-se numa sociedade urbanizada, os Pinto Alves, Morais Barros, Thiollier e Freitas Valle, entre outros, aproximavam-se da elite. Essa população procurava acomodar-se nos bairros "mais elegantes" (Homem, 1996:60), assumindo para sua imagem o status da região e das elites que ali viviam.

As ruas da cidade que se delineava passam então a ser ocupadas por pessoas cuja vivência, até então, se restringia ao ambiente da casa patriarcal, e se efetuam transformações que visam a melhorar a estrutura e aspecto da cidade. Ambientes públicos de regiões valorizadas ganham aspecto europeu, a cidade é embelezada. Paralelamente a essas mutações físicas, as mentalidades ligadas às teorias científicas e sócio-políticas mais atuais, diante de uma situação de aparente prosperidade, caracterizam-se pelo otimismo e a certeza. A chegada da modernidade é sinalizada pela valorização das ciências (muitas vezes traduzidas em novidades tecnológicas) e da racionalidade, constituindo estas, conjuntamente, os alicerces do século XIX (Costa \& Schwarcz, 2007).

Esses novos temperos (a valorização do belo, o otimismo, a certeza, a racionalidade, a ciência, veiculados principalmente pela imprensa), formam um caldo cultural que deixa marcas visíveis no espaço público e privado, na arquitetura, no urbanismo, no modo de viver paulista. Mais do que trazer novos sabores, aprimorar o paladar, essas 'especiarias' vinham conservar e, ao mesmo tempo, camuflar a mentalidade tradicionalista da elite local ${ }^{12}$. Essa imagem parece trazer às claras, ou até

${ }^{12}$ A metáfora dos 'temperos' é sugerida pela $\operatorname{Prof}^{\mathrm{a}} \operatorname{Dr}^{\mathrm{a}}$ Marilza de Oliveira (c. p.) com base no empreendimento europeu de busca por especiarias no Oriente para conservar suas iguarias, bem como no comércio do sal descoberto no Brasil, alvo de atenção de franceses e holandeses na costa brasileira. 
mesmo resolver, o impasse entre ruptura e continuidade que a literatura historiográfica e sociológica atribui ao período.

Essa alternância de continuidades e rupturas na sociedade paulistana da época em estudo (Frehse, 2007: 83) gera um contexto marcado por tensões. Ligada a um passado rural e aristocrático, essa sociedade buscava influências estrangeiras ${ }^{13}$, modernas, cosmopolitas, que se manifestavam em planos diversos, como os de vestuário, alimentação. Ao mesmo tempo, buscava definir traços de identidade em elementos locais (como os do paulista bandeirante, empreendedor e corajoso), mais ligados à tradição. Para atender, no campo da educação, às novas necessidades desse grupo que almejava o novo e, no entanto, se prendia ao passado; e às exigências do processo de urbanização da província, estabeleceu-se a Escola Normal da Capital, em cuja constituição se refletiram essas dialéticas, das quais ela foi também produto e produtora.

A alternância de continuidades e rupturas também se verifica na ordem política. Há um grande risco, ao se tratar da Independência do Brasil, de se tomar superficialmente esse acontecimento e salientar demasiadamente a importância da proclamação da República, tomando-a como o marco de uma nova era. Este acontecimento é apenas parte de um conjunto de transformações pelas quais passou o país naquele período (Costa, 2007:453), estando intrinsecamente ligado a fatos ocorridos ou iniciados ainda durante a Monarquia, como a decadência das oligarquias, a abolição, o intenso movimento imigratório, o processo de industrialização, etc.

\footnotetext{
${ }^{13}$ Em particular, francesas.
} 


\subsection{A difusão cultural}

O século XIX caracterizou-se por apresentar organizações que tiveram papel relevante na formação cultural da sociedade. Em um período em que se pregava o progresso da civilização através do conhecimento, e a intelectualidade era altamente valorizada, tais iniciativas vinham atender aos anseios dessa sociedade. Esses centros resultavam também, e talvez principalmente, do processo de sofisticação da vida urbana. Atendiam, então, as elites, que desejavam mostrar-se ilustradas, sendo também, ao menos em tese, uma forma de, no dizer da época, 'civilizar' os contingentes menos educados.

São os espaços da cultura letrada, dos quais são exemplo, entre outros, os Gabinetes de Leitura, cuja primeira unidade foi estabelecida no Rio de Janeiro em 1857 e posteriormente difundida para outras $\operatorname{províncias~}^{14}$. Esta forma de difusão cultural, apesar de sua repercussão no período monárquico ${ }^{15}$, possuía caráter não oficial. Nesse sentido, a escola pública era a única opção institucional de acesso ao conhecimento letrado em fins do século XIX.

É característica das instituições escolares de modo geral injetar ou reforçar nos alunos e na comunidade escolar disposições sócio-culturais por meio do reconhecimento e valorização de elementos seletos de cultura (como autores específicos, as disciplinas de estudo, comportamentos, etc.), disposições estas que são exercitadas nas práticas escolares, marcadas pela reprodução.

Ao se considerar a estruturação da primeira Escola Normal paulistana, não se pode ignorar que se trata não apenas de um núcleo gerador e reiterador de habitus, mas

\footnotetext{
${ }^{14}$ Sobre os Gabinetes de Leitura, em particular sobre sua difusão na Província de São Paulo, cf. Martins, 1997.

${ }^{15}$ Martins, 1997:334 destaca que, ainda no início da República (1900), a instituição já tinha desaparecido em cerca da metade das cidades do interior de São Paulo que abrigavam gabinetes.
} 
de um núcleo irradiador. Assim, a estruturação desse instituto potencializou não somente a expansão dos conteúdos ligados ao ensino, mas de um habitus determinado pelas identidades sociais, culturais e econômicas de seus dirigentes.

\subsubsection{O Ensino Público e a Escola Normal da Capital}

A insuficiência das escolas e do ensino público em seus primeiros anos de existência é atestada em vários registros (cf. Marcílio, 2005; Bauab, 1972; Tanuri, 1979). Para o ensino, que se limitava à leitura e escrita, às quatro operações e à religião, não havia material didático apropriado, sendo utilizadas cartas particulares ou jornais. A respeito da precariedade do ensino público, o inspetor geral da Instrução Pública chegou a relatar em 1885 que faltava tudo na província, professores, escola e inclusive alunos (Hack, 2002:55 apud Oliveira et alii, 2009).

A Escola Normal da Capital São Paulo, por ter surgido ainda no período imperial, carregava consigo o peso do progressivo declínio do antigo sistema, associado ao atraso, diferentemente da república, vinculada à ideia de modernidade. A Escola foi inaugurada duas vezes (1846 e 1874) e fechada após poucos anos de funcionamento. A deficiência da ENC em sua primeira versão é descrita pelo Inspetor Geral da Instrução Pública em relatório ao governo:

Esta será tudo quanto se quiser, mais (sic) de Escola Normal só tem o nome [...]. A escola é de necessidade tão indeclinável que 
escusado é demonstrar; mas na atualidade não canso de repetir:

não se pode contar com ela para nada, é antes nociva." 16

A despeito da insuficiência da escola e do ensino público no período, as expectativas com relação a seu poder regenerador e civilizatório eram grandes. Podem ser exemplificadas no discurso do Presidente da Província Sr. João Theodoro, na ocasião da reinauguração da $2^{\mathrm{a}}$ Escola Normal:

Assim se transformam as gerações, afugentam-se as sombras da ignorancia, claream-se os espiritos, e dominam as sciencias. (Rodrigues, 1903:79)

Com efeito, o elevado contingente populacional que São Paulo recebeu em fins do XIX e sua assunção a centro político e econômico demandavam a implantação e expansão de uma nova escola, de qualidade, cuja sustentação estaria nas escolas normais, dada a importância que se passou a atribuir ao preparo e treinamento dos professores. Diante desta necessidade inaugurou-se, em 1880, a terceira Escola Normal pública de São Paulo.

O período sobre o qual incide esta análise caracterizou-se pelo estabelecimento de diversas instituições urbanas (Secretarias, Departamentos e outras instâncias de organização) e a consequente formalização e burocratização das relações que normalmente se viabilizavam, em âmbito político e institucional, através da escrita, processo que avançou especialmente com a instauração da República. Esse processo estendeu-se ao âmbito educacional por meio da institucionalização da escola pública

\footnotetext{
${ }^{16}$ Relatório do Inspetor Geral da Instrução Pública, Diogo M. Pinto, ao Presidente da Província, apud Monarcha, 1999:47-48, grifo nosso.
} 
(Castanho, 2007:39 ${ }^{17}$, que ganha então centralidade na vida cultural brasileira, e passa a ter uma vida cotidiana e administrativa documentalmente registrada.

No entanto, muitos documentos de arquivo são eliminados pelo tempo. Contando com as fontes disponíveis atualmente, consultamos, no Centro de Referência em Educação Mário Covas, os livros de Correspondência Oficial (1894), Registro de Diplomas (1887, 1894-1899), Livros de Matrícula (1888-1899), Atas da Congregação (1894-1898), Livros de Ponto (1894-1895), e a Galeria de Diretores, Professores e Funcionários. Nesses documentos, buscamos levantar as listas de alunos diplomados pela instituição, os professores, práticas e relações pedagógicas e administrativas da ENC, bem como os valores históricos e sócio-culturais implicados nessas relações.

\subsection{A Terceira Escola Normal}

A terceira Escola Normal, inaugurada em 1880, abrigou tensos conflitos políticos e ideológicos na sua primeira década. Apesar de vinculada a um Estado católico, a instituição se compunha de docentes associados ao positivismo, e outros contrários a essa corrente filosófica. A direção da Escola, nesse período, buscaria minimizar a atuação desses professores como propagandistas da Religião da Humanidade. Cumpre ressaltar que até a Grande Reforma da ENC, empreendida pelos republicanos, a diretoria da Escola é constituída de bacharéis, ou seja, de sujeitos ligados à Academia de Direito de São Paulo (ADSP).

\footnotetext{
${ }^{17}$ In: Nascimento et alii (orgs.), 2007.
} 
O primeiro diretor na nova etapa da instituição, Dr. Vicente Mamede de Freitas, atuou entre 1880 e 1882, sendo sucedido pelo Dr. Paulo Bourroul, que exerceu o mesmo cargo de 1882 a 1884.

Entre os anos de 1884 e 1887, o docente de História e Geografia Dr. José Estácio Corrêa de Sá e Benevides assumiu interinamente a direção da Escola. Formado pela ENC e também pela ADSP, apesar de não fugir ao perfil típico dos dirigentes e docentes do período republicano no que se refere a sua formação ${ }^{18}$, atuou intensamente contra a vertente positivista dentro da ENC no período monárquico. O grupo de professores que a encabeçava era criticado por difundir o positivismo na Escola e na comunidade, assim como por assumir posturas contrárias ao favorecimento pessoal na aprovação de alunos e denunciar publicamente tais fatos (Monarcha, 1999). Em ofício ao governo, expressa sua insatisfação contra o grupo e sua disposição em combatê-lo:

[...] julgo de meu dever levar-se ao conhecimento de V. Exa. um fato abusivo por eles ${ }^{19}$ praticados (sic) - a propagação do positivismo nesta Escola.

Entendo que, embora seja pela nossa Constituição do Império garantida a liberdade de pensamento e de consciência, e portanto tenha (sic) os Professores o direito de seguir este ou aquele sistema filosófico e científico, este direito tem limites estabelecidos pela própria Constituição e mais legislação do Império.

Os Professores acima referidos transpõem tais limites porque - saindo do terreno puramente metodológico - atacam diretamente os princípios

\footnotetext{
${ }^{18}$ Galeria de Diretores, Professores e Funcionários. Centro de Referência em Educação Mário Covas Acervo da Escola Caetano de Campos.

${ }^{19}$ O pronome "eles" refere-se aos professores Godofredo José Furtado, Cypriano José de Carvalho e Antonio da Silva Jardim que, segundo Benevides, são franca e abertamente Positivistas (Sá e Benevides, 1885 apud Monarcha, 1999: 123).
} 
fundamentais da Religião do Estado para pregar a Religião da Humanidade fazendo um verdadeiro curso de filosofia primeira de A. Comte.

Diversas provas escritas há de alunos em que, em vez de teorias de Física ou de Química, vêem-se reproduzidas as preleções do respectivo Professor.

Estes fatos de propaganda já têm produzido resultados maus entre o professorado público.

É pois de urgente necessidade reprimir tal propaganda. Para isso há necessidade de uma reforma no Regulamento de 30 de Junho de 1880, dando-se ao Diretor meios dos quais atualmente não dispõe. (Sá e Benevides, 1885. apud Monarcha, 1999: 124).

Sá e Benevides, oriundo de família tradicional e aristocrática, não aceita as novas vertentes políticas e filosóficas, e as ataca de frente. O catedrático ligava-se, também, ao catolicismo. Era "muito católico" e, "sempre que podia, colocava um pouco de religião nas suas aulas" ${ }^{20}$. Por ter um perfil conservador, houve espanto por parte dos alunos ao verificarem que, após oficialmente iniciada a reforma do ensino em 1890, o lente continuaria na Escola:

- Então, sempre é certo que o Dr. Benevides não volta? - perguntava um recémchegado, mal terminava o preâmbulo dos cumprimentos.

- Simples boato: vi-o ainda hontem na Secretaria, e foi elle quem recebeu o meu requerimento. Estava lá tambem o novo Director; por sinal que os dois conversam com bastante cordialidade.

\footnotetext{
${ }^{20}$ Segundo consta no relato de ex-aluna registrado em Rocha, 1999: 143.
} 
- Mas o Dr. Benevides já requereu trez meses de licença e consta que não voltará. Dedicado como foi sempre á monarchia, sua posição de lente de historia patria nada tem de facil. (Rodrigues 1930: 203)

O espanto do normalista registrado nas memórias de Lourenço Rodrigues, exaluno e ex-professor na ENC, resulta não apenas do fato de Sá e Benevides ser ligado à monarquia, mas principalmente da incoerência que sua manutenção no corpo docente deixa transparecer nas bases da reforma encabeçada pelos republicanos, visto que the correspondia a cadeira de História. Surpreende que, mesmo em período republicano, Benevides mostra-se uma figura importante no interior da Escola, atuando por vezes como diretor interino, vice-diretor ou secretário da congregação. Sua presença na estrutura administrativa da ENC é quase uma constante na história da instituição, tanto na Monarquia como na República.

Com o intuito de acalmar definitivamente os ânimos exaltados com os conflitos internos da Escola, é nomeado diretor o Cônego Manoel Vicente da Silva (1887-1889), que deu sequência à empreitada de Benevides contra os positivistas. Ligado à intelectualidade local, foi vice-presidente da Sociedade dos Homens de Letras e Membro do Instituto Histórico e Geográfico.

Em 1889, a figura do bacharel estará de novo à frente da direção da Escola, representada pelo Desembargador Manoel Jorge Rodrigues. Formado pela ADSP e monarquista, Rodrigues acaba saindo da direção devido à intensificação dos atritos com o corpo docente.

Tomando a Escola como símbolo da República, os republicanos, agora no poder, tencionarão reverter a situação de precariedade do ensino público em geral, constatando a necessidade de se promover uma grande reforma no ensino, que deveria começar pela 
estruturação da Escola Normal, centro de formação de professores. Além de idealizarem a civilização e humanização da sociedade por meio da educação, encontraram nesta uma importante ferramenta na consolidação do novo regime.

À frente dessas reformas esteve Rangel Pestana, político, jornalista, e professor do Mackenzie College. Responsável pela elaboração da proposta educativa do Partido Republicano, foi indicado também para organizar o projeto de organização da Escola Normal, oficializado no decreto $\mathrm{n}^{\mathrm{o}} 27$, de 12 de março de 1890.

Por indicação de Rangel Pestana, o então presidente do estado Prudente de Morais Barros $^{21}$ nomeou o Dr. Antonio Caetano de Campos para diretor da Escola Normal $^{22}$. Carioca e formado em Medicina no Rio de Janeiro, sua breve atuação junto à Escola foi marcante, provavelmente por tê-la dirigido justamente no momento de sua reestruturação. Suas contribuições levaram à consagração de seu nome, posteriormente vinculado à Escola que, na década de 30, passou a se chamar Escola Normal Caetano de Campos.

Cumpre ressaltar que a primeira e segunda Escola Normal, inauguradas e extintas durante o Império, tinham sido geridas por bacharéis de Direito, assim como a terceira - até o momento em que Caetano de Campos assume a direção. A escolha de um médico para diretor da Escola sugere a possibilidade de um paralelo entre a postura higienista no âmbito da saúde pública e a proposta de higienização implícita no projeto educacional republicano, que começaria por expulsar o 'vírus' da ignorância, fortalecido pelo catolicismo e o ensino religioso, e teria como resultado uma sociedade saudável e culturalmente homogeneizada.

\footnotetext{
${ }^{21}$ Em oposição à Monarquia, cujo sustentáculo estava na classe senhorial, a República estabeleceu-se pela aliança entre grupos ativos da classe média e representantes do setor mais dinâmico da classe senhorial (Costa, 2007: 455). Maria Cecília Naclério Homem (1996: 60) cita os Morais Barros entre os sobrenomes de famílias da classe média alta de São Paulo na época em estudo. O novo regime contou também com adeptos entre os militares de patentes mais baixas e alunos da Escola Militar.

${ }^{22}$ Segundo o Prof. Dr. Carlos A. P. Bacellar (c. p.), as inovações ocorridas na virada para o século XX estavam frequentemente associadas a médicos, considerados agentes da modernidade, relação ilustrada pelo dr. Luís Pereira Barreto.
} 
Em sua gestão, Caetano de Campos buscou providenciar para a Escola um prédio que correspondesse não só às novas necessidades estruturais impostas pela reforma republicana, como também à grandeza do progresso e civilização nela representados. Essa mudança, concretizada em 1894, deve ter sido altamente impactante para a sociedade da época. A Escola não apenas passava a ocupar um prédio novo e de arquitetura imponente, ganhando visibilidade no espaço urbano, mas ganhava também uma nova organização interna, estruturada principalmente no novo perfil do quadro da diretoria e do professorado.

A grandiosidade de seu edifício fazia jus à sua localização. De fato, à medida que a região do triângulo, espaço das elites, tornou-se mais comercial, as famílias mais tradicionais ali residentes passaram a mover-se para a Santa Ifigênia, Campos Elíseos e Higienópolis. No meio desse trajeto encontra-se a Praça da República, local onde se estabeleceria a Escola Normal, o que parece indiciar que a escolha da região para construção do prédio não foi aleatória.

A Escola passava a se situar, portanto, onde estavam aqueles que pretendia atender: entre o triângulo onde residiam as famílias de elite, com o qual se conectava pelo Viaduto do Chá, inaugurado em 1892; e os Campos Elíseos e Higienópolis, bairros nobres que vinham se formando, para onde se dirigiam as gerações de descendentes dos grandes cafeicultores inicialmente instalados na rua São Bento e proximidades (Homem, 1996). Assim, o prestígio que então ganhava a região onde vinha se instalar o prédio da ENC conferia prestígio também à instituição.

O deslocamento da ENC da rua da Boa Morte $^{23}$ para uma região que correspondia ao novo habitat da elite paulistana é a estratégia que dá concretude à ideia de transformar a Escola em símbolo de poder da nova ordem. Não por acaso, o prédio

\footnotetext{
${ }^{23}$ Posteriormente denominada rua do Carmo.
} 
que passaria a abrigar não somente a Escola Normal, como a Escola Modelo anexa ${ }^{24}$ e o Jardim da Infância, foi construído com dinheiro e no espaço destinados, nos tempos monárquicos, a uma catedral católica (Rodrigues, 1930:190). O redirecionamento dos fundos para a construção da Escola trazia, implicitamente, a mensagem de inauguração de novos tempos: saíam de cena as trevas e a fé no desconhecido, entravam a luz, a razão, a fé na ciência. Esse é mais um aspecto que sinaliza a constituição da Escola como símbolo do novo regime, associado a valores cientificistas, correlação reforçada pelo lócus do edifício, a Praça da República.

Do ponto de vista organizacional, a reforma republicana da Instrução Pública foi apoiada pela equipe do Mackenzie College ${ }^{25}$, colégio protestante, renovando as práticas pedagógicas que nortearam as reformas republicanas implementadas (Oliveira et alii, 2009). Mostra-se interessante a atitude dos reformadores que, para estabelecer um sistema leigo de ensino, buscaram o apoio dos protestantes, que inclusive assumiram postos de direção na ENC e na Escola Modelo, anexa à primeira, onde os alunos exerciam a prática de ensino. Conforme aponta Hilsdorf (2003:62), a visão dos republicanos sobre educação baseava-se em três padrões: o católico, associado à Monarquia, recusado pelos reformadores; o dos protestantes, caracterizado pelo positivismo e cientificismo, considerado aceitável; e o ideal, que seria o modelo republicano, representado por um Estado educador que pretendiam construir contando, para isso, com o apoio da escola protestante.

Outro diferencial trazido pela equipe do Mackenzie College foi a ênfase no ensino de língua nacional. Esta era uma preocupação importante na época, pois sendo a

\footnotetext{
${ }^{24}$ A Escola Modelo Anexa consistia em uma instituição de ensino primário na qual se pretendia aplicar as metodologias de ensino mais atuais da época, as quais eram ensinadas na Escola Normal. Nela, os normalistas realizariam a 'Prática de ensino', correspondente ao estágio dos cursos atuais de licenciatura. A designação da escola não foi arbitrária: as escolas modelo criadas nesse período deveriam realmente servir de modelo para o ensino público que naquele período buscava se estruturar e homogeneizar suas práticas.

${ }^{25}$ O Mackenzie College do séc. XIX corresponde ao atual Colégio Mackenzie.
} 
língua um forte marcador identitário, e havendo, entre os dirigentes políticos, a preocupação de se definir uma identidade nacional, o ensino público deveria ser zeloso com os estudos de língua e literatura. Tal fato se destaca ainda mais se considerarmos que, nas escolas de imigrantes, o português era, em geral, pouco ou mal ensinado, muitas vezes por um professor que não dominava esse idioma. E nos colégios católicos, particularmente aqueles frequentados pelos filhos das elites, a instrução se fazia com o emprego da língua francesa, ficando a língua portuguesa em segundo plano (Oliveira et alii, 2009).

Após o falecimento de Caetano de Campos, em 1891, a ENC passa a ser dirigida por Gabriel Prestes, que não somente era formado pela Escola, como obteve distinção no curso $^{26}$. Prestes atuava no meio jornalístico e como deputado, tendo se afastado da política quando assumiu a direção da Escola. O fato de Prestes ser militar com patente de Major indicia o envolvimento e participação dos militares no novo regime e em suas reformas.

O aspecto militaresco dessa direção se refletirá, entre outros fatores, na tentativa de se estabelecerem práticas e um ambiente marcados por controle e disciplina (Oliveira, 2008), tanto entre os alunos como também no corpo docente, que deveriam se submeter às imposições superiores. Em decorrência de mudanças políticas que vinham ocorrendo desde $1895^{27}$, e insatisfeito com as críticas à reestruturação da ENC e com os novos regulamentos da instrução pública, Gabriel Prestes afasta-se do cargo de diretor da Escola e da instrução pública (Monarcha, 1999: 215).

\footnotetext{
${ }^{26}$ Posteriormente, a formação como normalista seria pré-requisito para se atuar como professor ou diretor escolar. Esse fator funcionaria como elemento de agregação dos profissionais ligados à educação, favorecendo a criação e o fortalecimento de um espírito de grupo nesse ambiente.

${ }^{27}$ Entre essas mudanças, registram-se a saída de Cesário Motta Junior do cargo de Secretário dos Negócios do Interior (1895) e o fim do governo de Bernardino de Campos (1896), sucedidos respectivamente por Alfredo Pujol e Alberto Campos Salles. Nessa nova gestão política, Prestes não mais encontrou o apoio que tinha com a administração anterior, com a qual estabelecia aliança e que estava em concordância com o direcionamento que vinha sendo dado à reestruturação do curso normal (Monarcha, 1999: 215).
} 
Entre 1898 e 1901, a ENC volta às mãos de um bacharel, o Dr. João Alberto Salles, formado em Direito pela ADSP e autor de livros de direito e política. Essa é, porém, a última vez em que um bacharel ocupa o posto de direção da ENC.

Até esse momento, estiveram à frente da ENC um médico, um militar, e uma longa lista de bacharéis, que conferiam a instâncias e processos escolares aspectos de sua formação e visão jurídica, como ao interpretar a Congregação como um tribunal:

Nós - Congregação - como tribunal julgador, estamos adstrictos á lei que define a falta, a classifica como mais ou menos grave, estabelece as penas correspondentes e o modo ou processo de sua imposição ${ }^{28}$.

O caráter bacharelesco da Escola e do ensino teria um fim - ainda que apenas em alguns aspectos. A profissionalização da carreira do magistério resultante, em parte, dos esforços empreendidos pelos reformistas, chega também ao âmbito de cargos mais altos da educação. Assim, em 1901 a direção da Escola é assumida pelo normalista Oscar Thompson $^{29}$, que se manterá no cargo de diretor até 1920.

Essa alteração no perfil de dirigentes da Escola, no que se refere à sua formação, parece resultar, de um lado, do processo de profissionalização ocorrido no âmbito da educação, e, de outro, mas associado ao primeiro, da autonomia da ENC em relação à ADSP, o que decorre da criação de um grupo identitário, propiciado pela nova ordem sócio-política do país.

Junto a uma série de outras modificações estruturais que ocorreram nesse período, o fato proporcionou a idealização de um "período áureo" da reforma da Escola

\footnotetext{
${ }^{28}$ Atas da Congregação, 19 de Novembro de 1895. Acervo da Escola Caetano de Campos.

${ }^{29}$ Thompson havia então dirigido a Segunda Escola Modelo, que funcionava no edifício antigo da Escola, na rua da Boa Morte.
} 
referente aos anos da gestão Prestes (1893-1898). A partir da imagem de eficiente estruturação e organização da Escola e do ensino público a que se procedeu nesse momento, e da consolidação de uma imagem de qualidade e eficácia a ela associadas, a ENC seria reconhecida como representante da "mais alta excelência escolar", monopolizando, ao lado do Ginásio de São Paulo, a educação secundária pública até as primeiras décadas do século XX (Perosa, 2004: 75).

\subsubsection{O corpo docente}

Apesar de o processo de reforma do ensino apresentar uma aparência de ruptura em relação ao período monárquico, imagem construída pelos próprios reformadores, diversos elementos da educação daquele período se estenderam ao período republicano. Registros apontam que, a partir da terceira inauguração da Escola, em 1880, um grupo de docentes republicanos e positivistas buscava atuar de forma supostamente 'inovadora', e divulgar ideias modernas entre os alunos, contrariando a linha católica e monárquica então característica da instituição (Monarcha, 1999).

A referência e crítica ao grupo positivista verificadas na Monarquia ocorrem também no período republicano, originadas no interior do corpo docente. No entanto, neste momento há uma inversão: a direção da Escola é que representa o suposto 'positivismo' contra o qual se levanta o agressor. O protagonista desse episódio é o prof. Moura Lacerda, que pede à Congregação para ampliar sua disciplina, inglês, para além de dois semestres, como era ministrada então. Por ter seu pedido negado, o professor, ao sair da reunião, queixou-se diante de "empregados subalternos", assim "concorrendo para a indisciplina", e chamou à direção e ao grupo de professores de 
"claque positivista", sendo indiscreto quanto ao "que se passa nas sessões da Congregação",30.

Aproveitando o teor da discussão, o professor em pauta foi criticado por abordar questões religiosas em suas aulas, num período em que o ensino buscava incorporar um caráter laico:

E tanto mais isto me impressionára quanto é sabido certamente que o professor M. Lacerda, em suas aulas de inglez, esperdiça o tempo discutindo theses philosophicas e religiosas (Ata da Congregação, 12/12/1895)

Parece-nos, deste modo, que o adjetivo positivista não remete ao positivismo propriamente dito, mas a aspectos dessa doutrina tomados genericamente, servindo mais como uma forma de taxar um grupo adversário.

Assim como a crítica ao 'positivismo' aparece, ainda que de modo episódico, no período republicano, a proclamação da República e o início da reforma na ENC não representaram, necessariamente, a saída de docentes ligados a princípios mais tradicionais. Foi exonerado, nesse momento, o Padre Camillo Passalacqua. No entanto, permaneceu o Dr. Sá e Benevides, lente de Geografia e História que durante sua atuação como diretor em 1886 atacou duramente o grupo de docentes denominados positivistas (Monarcha, 1999: 143).

Assim, vemos que os aspectos de continuidade e ruptura permeavam o ambiente escolar também no que concerne aos docentes que nele atuavam, muitos dos quais

\footnotetext{
${ }^{30}$ Atas da Congregação, 12 de Dezembro de 1895. Acervo da Escola Caetano de Campos.
} 
bacharéis formados pela Academia de Direito de São Paulo (ADSP), ligados também à política e às instituições intelectuais da época (Rocco, 1946:102-103).

Visando a ilustrar esse grupo, destacaremos algumas figuras do corpo docente, em particular aquelas relacionadas ao ensino de Língua Portuguesa. Delinear o perfil do corpo docente mostra-se relevante visto que os professores tinham contato direto com os alunos, sendo para estes modelos pedagógicos e culturais. Nesse sentido, interessamnos especialmente dados que indiciem um maior vínculo com a inovação ou com a tradição, assim como dados sobre a formação desses professores, intrinsecamente relacionada ao tipo de conteúdos que difundiam e aos valores sócio-culturais neles implicados.

As aulas de língua portuguesa, no momento da terceira inauguração da Escola, foram inicialmente ministradas pelo catedrático e diretor Dr. Vicente Mamede de Freitas. Ao fim de 1882, foi aprovado em concurso para lecionar na Academia de Direito, deixando então seus cargos na Escola Normal. No ano seguinte, a cadeira vaga é posta em concurso, no qual foi aprovado o Dr. Antonio da Silva Jardim, também bacharel em Direito pela ADSP e professor da aula anexa desde 1880. Este professor conduziu a novos rumos o ensino de língua materna, adotando a então inovadora metodologia de João de Deus ${ }^{31}$ para a alfabetização (Monarcha, 1999), fato que desmistifica a ideia de que as principais novidades no ensino e estrutura da Escola Normal implementadas no final do século XIX foram trazidas a partir da instauração da República e de iniciada a reforma da instrução pública.

Silva Jardim foi um dos principais representantes do positivismo na instituição, juntamente com os professores Cypriano José de Carvalho e Godofredo Furtado. Esse grupo foi fortemente combatido pelos professores mais tradicionalistas e pela direção da

${ }^{31}$ A Cartilha Maternal de João de Deus (1877) descartava o ensino pelo tradicional método de soletração. Fundamentava-se na análise de sílabas no contexto das palavras, e não isoladamente. A versão digitalizada da obra está disponível em: http://purl.pt/145/1/P1.html 
Escola, da qual estava à frente o Dr. Sá e Benevides. Devido à intensificação das tensões internas relacionadas aos conflitos ideológicos, Silva Jardim acabou por exonerar-se do cargo, em 1886 (Monarcha, 1999: 146).

A primeira cadeira é então assumida interinamente pelo romancista e gramático Julio Ribeiro, $2^{\circ}$ colocado no concurso de 1882, em que se aprovara Silva Jardim. Nascido em Minas Gerais, estudou o secundário em Baependi (MG), e chegou a inscrever-se no Colégio Militar, no Rio de Janeiro, mas não concluiu o curso. Lecionou no Colégio Culto à Ciência, em Campinas, e atuou também como jornalista. Autor de $O$ Padre Belchior de Pontes (1867) e, famoso com a publicação de A Carne (1888), não obteve prestígio como romancista - pelo contrário, era mal visto nesse aspecto, pois abordou temas polêmicos ligados à sexualidade e ao papel da mulher na sociedade. No entanto, destacou-se na área dos estudos linguísticos, obtendo reconhecimento como gramático e filólogo.

A permanência de Julio Ribeiro na ENC foi breve. Assumiu as aulas de Silva Jardim em 1886, e nesse mesmo ano inscreveu-se no concurso para a cadeira de Português, que assumira interinamente. Porém, antes que se realizassem as provas, foi aprovado como lente de Latim na ADSP, abrindo mão das aulas na ENC e de concorrer à vaga da primeira cadeira.

O outro inscrito, Dr. Carlos Reis, atuava como vereador em São Paulo e solicitou nomeação para o cargo, sendo desnecessária a realização do concurso por falta de concorrentes. Seu pedido foi deferido em abril de 1887, e em seguida assumiu as aulas. Carlos Reis havia se formado na ENC em 1876 com distinção em todo o curso, matriculando-se, três anos depois, em Direito na ADSP. Exonerou-se do cargo na ENC em 1907, após dez anos de atuação, para assumir cargo público na Secretaria do Interior. Foi um dos fundadores do IHGSP. 
Talvez a grande reforma do ensino normal na capital paulista se deva à reestruturação do currículo e à ampliação das cadeiras do curso. Em consequência dessa mudança, a disciplina Português passa a corresponder a duas cadeiras. A segunda cadeira é assumida pelo Prof. João Vieira de Almeida, ex-professor do Colégio Culto à Ciência, de Campinas, e apontado por Julio Ribeiro como um dos "cultores mais competentes do idioma pátrio" (Rodrigues, 1930: 203). O docente também se dedicou ao estudo de poetas latinos e clássicos quinhentistas, e foi colaborador na revista do IHGSP (Rocco, 1946: 97). Vieira de Almeida permanece na ENC até 1894, quando é então aberto concurso para sua vaga. Inscrevem-se o gramático Eduardo Carlos Pereira e Carlos Lentz de Araujo, ambos protestantes, sendo este último aprovado em primeiro lugar.

A breve apresentação a respeito da formação e vida acadêmica dos docentes de língua portuguesa revela um intenso trânsito entre a Escola Normal e a Academia de Direito. Ao mesmo tempo em que bacharéis assumiam postos de professor naquela escola, o caminho inverso também ocorria: havendo oportunidade, os docentes da ENC migravam para a ADSP, como fizeram Vicente Mamede e Julio Ribeiro. Tal conexão parece contraditória visto que a terceira Escola Normal, especialmente depois de assumida pelos republicanos, pretendeu instituir-se nova e inovadora, no que concerne a suas concepções, práticas e objetivos sociais e políticos.

Nesse sentido, a presença de sujeitos de cultura bacharelesca pode ser um fator de frustração dessas metas renovadoras, por ser o bacharel o intelectual da tradição, caracterizado por manifestar "atração pelo saber ornamental, culto à erudição linguística, e cultivo do intelectualismo" (Adorno, 1988: 158), o que o distanciava, na prática, dos objetivos da reforma republicana na educação. Isso significa dizer que a presença de bacharéis na direção e docência da ENC tinha por efeito afastar a 
possibilidade de se executar uma verdadeira reforma no ensino, quando considerado o objetivo maior das propostas reformistas, que era o de proporcionar luz e razão à sociedade para 'civilizá-la', ideia que vinha ganhando espaço na sociedade, segundo a qual as escolas seriam o brado de salvação da sociedade moderna. ${ }^{32}$

Ainda que esse ideal fizesse também parte do pensamento dos bacharéis, o alcance desse "processo civilizatório" não atingia com sucesso as classes populares, o que convergia com o comprometimento desse intelectual. Ligado às oligarquias tradicionais e aos "processos de exploração econômica e de dominação política" 33 , o bacharel reproduz o status macro da sociedade, com suas hierarquias e relações de poder, no ambiente micro das instituições em que atuava, assegurando uma situação de estabilidade, a despeito da aparente mudança em diversos âmbitos.

Nesse sentido, é possível interpretar o bacharel como um radical, sujeito revoltado, de ideias transformadoras, mas de ações harmonizantes e conciliatórias (Candido, 1988). Esse perfil do bacharel inibe-lhe uma atitude de ruptura definitiva, posto que suas ideias, ao contrário das do revolucionário, não se concretizam em ações transformadoras (Candido, 1988:5) e na efetiva mudança do status quo.

No âmbito da educação, as expectativas com relação ao potencial transformador da Escola Normal foram bastante frustradas, justamente por ter em seu quadro administrativo e docente indivíduos que não concretizavam ideias inovadoras. Operando como a mais importante instituição de formação de professores da época e da região, a ENC não atendia, efetivamente, as necessidades do ensino público. Em 1898, o Secretário de Estado Interino dos Negócios do Interior registrava que a Escola não havia preparado professores nem fornecido mestres, "não obstante os esforços das hábeis

\footnotetext{
${ }^{32}$ Discurso proferido pelo Dr. Paulo Antonio do Valle, professor da $1^{\text {a }}$ cadeira da Escola Normal na ocasião de sua segunda inauguração, em fevereiro de 1875. Registrado em Rodrigues 1930: 81.

${ }^{33}$ Faria \& Lange, 1979 apud Adorno, 1988: 159.
} 
direções" que vinha tendo ${ }^{34}$, possível efeito da forte relação da ENC com a ADSP, cujos diplomados se encaminhavam a postos de comando na política e burocracia (Schwarcz, 1993:184). Similarmente ao que ocorria entre os bacharéis, os normalistas dirigiam-se principalmente a cargos administrativos, ou ao magistério em nível superior e não primário, não suprindo, deste modo, as necessidades das escolas.

\subsubsection{A composição do corpo discente}

Inserida num processo radical de transformação social, a reformulação e sólida estruturação da ENC, tida como pólo difusor de alto nível educacional, fez com que a escola normal pública continuasse a ser para poucos, porém, privilegiados, visto que se compunha primordialmente dos filhos de famílias emergentes - mas não da elite cafeeira. Tal dedução se deve à comparação que realizamos entre os nomes registrados nos livros de matrícula e os sobrenomes da elite tradicional fornecidos por estudos historiográficos ${ }^{35}$, a qual resultou na verificação de que os nomes dos matriculados nos primeiros anos da reforma não são coincidentes com os sobrenomes da elite. Essa hipótese encontra respaldo no fato de que esse grupo econômica e socialmente privilegiado buscava residir nos bairros nobres, junto à elite cafeeira, incluindo as proximidades da ENC.

A análise dos registros de matriculados no fim do XIX mostra que os jovens ingressantes apresentavam-se à Escola a partir dos 15 anos, após terem concluído o

\footnotetext{
${ }^{34}$ Peixoto, 1898: 42 apud Monarcha, 1999: 213.

${ }^{35}$ Pires, 2006; Homem, 1996; Mello apud Homem, 1996.
} 
curso primário $^{36}$, de oito anos de duração. Muitos, porém, contavam mais idade e, já atuando como professores, buscavam atualização ou regularizar-se na profissão.

Além disso, revela que o maior fornecedor de alunos para a ENC era a própria capital. Entretanto, é também elevada a presença de alunos vindos do interior do Estado e de outras regiões do país e do mundo. Desse grupo, é possível que uns tenham nascido em outras localidades e acompanhado mudança da família para a capital, e outros se deslocado especialmente para estudar, vindo a residir em pensões e repúblicas. O afluxo de matriculados vinha tanto do oeste paulista (Campinas, Pirassununga, Rio Claro) como do leste, i.e., do Vale do Paraíba (Guaratinguetá, Pindamonhangaba, Taubaté, etc), incluindo cidades do Rio de Janeiro e Minas Gerais. Essas correntes são numericamente próximas, com destaque, porém, para as cidades do Oeste paulista. Vale ressaltar que, até então, o foco das cidades do Vale do Paraíba estava voltado para o Rio de Janeiro, onde estava a corte, situação que muda a partir desse momento (Pires, 2006).

Provavelmente, assim como ocorreu com a difusão dos gabinetes de leitura pelo interior de São Paulo, processo que se apoiou na existência de ferrovias nessa região, também a composição do corpo discente da Escola Normal reflete um movimento migratório que acompanha os seus trilhos, e certamente foi por eles facilitado.

A área a leste da capital paulista é servida pela Estrada de Ferro Central do Brasil $^{37}$, construída entre 1855 e 1864 para interligar São Paulo, Minas Gerais e Rio de Janeiro, onde estava a corte. Era "a mais importante ferrovia do país em termos de tráfego. No período da República, ela transportou quase metade dos passageiros e um quarto das cargas do país" ${ }^{\text {38 }}$. Ao ser concluído o trecho paulista da Central do Brasil, a economia cafeeira já estava em decadência (Stefani, 2007: 75). Serviria então para

\footnotetext{
${ }^{36}$ As opções para o ensino secundário eram o ensino Normal ou o Ginásio.

${ }^{37}$ Até 1890, essa linha se denominava Estrada de Ferro D. Pedro II. O novo nome foi atribuído quando a estrada chegou a São Paulo.

${ }^{38}$ Topik, 1987: 115 apud Stefani, 2007: 75.
} 
trazer as famílias ligadas à cultura do café para espaços mais urbanizados. A linha acompanha todo o Vale do Paraíba, pelas cidades de Cruzeiro, Lorena, Guaratinguetá, Taubaté, São José dos Campos, e Mogi das Cruzes. Apresentava também uma ramificação até a cidade de Bananal, importante produtora de café no início do século XIX.

A conexão entre a capital São Paulo e as cidades de origem dos alunos do oeste paulista se fazia principalmente por meio da Companhia Mogiana. Inaugurada em 1872 com o trecho entre Campinas e Mogi-Mirim, é expandida posteriormente na direção de Ribeirão Preto, chegando até Minas Gerais (Stefani, 2007: 53). São, portanto, principalmente de duas regiões os alunos imigrantes que irão procurar a Escola Normal: do Vale do Paraíba e da região Mogiana.

Em relação aos alunos diplomados, observamos que os dados a eles relativos refletem, ao mesmo tempo, aspectos do histórico da escola e da sociedade paulistana do século XIX. Observamos a repetição de vários sobrenomes, muitos dos quais provavelmente indiciam laço familiar. Entre os diplomados de 1891 estão as normalistas Anna de Camargo Barros e Gertrudes de Camargo Barros, e na sequência registra-se o nome de Maria Candida de Barros, possivelmente prima das duas primeiras. Destacam-se ainda os nomes de duas jovens da família Bonilha (Maria Amelia e Adelia) formadas em 1899, e os Von Atzingen (João, Felisbina e Maria), diplomados em 1891, 1897 e 1899.

Ao longo do período analisado, é possível notar certa irregularidade no que se refere ao número de diplomados, o que parece acompanhar o processo de reforma do ensino público ${ }^{39}$.

\footnotetext{
${ }^{39}$ Verificamos um declínio significativo no número de diplomados entre 1895 e 1897, com destaque para 1896. É possível que essa irregularidade se deva à criação de novos cursos, abrindo novas perspectivas de profissionalização, especialmente para os rapazes, como a criação da Escola Politécnica, em 1894, o que aparentemente impactou o número de matriculados no ano seguinte.
} 
Gráfico 1: $\mathrm{N}^{\mathrm{o}}$ de diplomados por ano

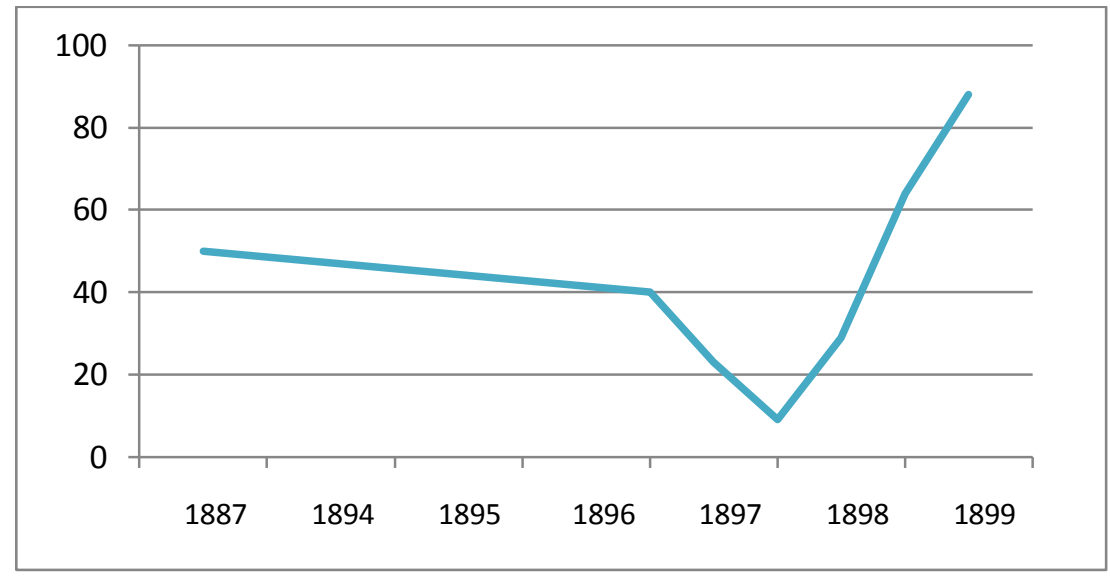

Considerando que o curso tinha duração de três anos, e que a transferência para o novo prédio se deu em 1894, o número de diplomados deveria tender a aumentar a partir de 1897, o que de fato ocorreu, como mostra o quadro acima. A elevação é ainda maior em 1898, ano em que se formariam os alunos ingressantes em 1896. Nesse momento, inauguram-se as aulas do Jardim da Infância (Rodrigues, 1930: 379), que se somará às escolas Modelo anexa e Complementar, e ao Ginásio do Estado. Essa melhor estruturação da escola e do ensino pode ter estimulado o aumento da procura pelo curso normal. No entanto, observamos também uma grande diferença entre o número de diplomados e matriculados, indiciando que uma parte significativa desse grupo não chegava ao final dos estudos.

No ano de 1898 verificamos haver maior ocorrência de sobrenomes estrangeiros em relação aos anos anteriores, o que se repete em 1899. Nesse período, diplomam-se alunos das famílias Guilice, Bellegarde, Grassí, Purgassi, Snell, Aldred, Coque, Roca, Lintz, Tolomony, Mallet, Lang, Berlinck, Salmann, Mc. Intyre, Backmann, e outras.

Parece que, aos poucos, a ENC foi ganhando credibilidade junto aos imigrantes. Nas famílias estrangeiras de situação econômica mais elevada, assim como entre a elite 
tradicional, os filhos eram muitas vezes educados em casa, normalmente por uma preceptora europeia (Lacerda, 2003: 169), como é exemplo a família Prado. Porém, estando as crianças já crescidas e sendo a Escola Normal pública uma instituição respeitada, tornava-se ela uma opção atraente, na medida em que preparava os rapazes para os estudos superiores ${ }^{40}$, e as moças para o magistério ou matrimônio.

Assumindo essa dupla finalidade, a ENC, já a partir de 1894, parece atender às novas demandas de formação escolar. De fato, é expressiva a inversão nos números de diplomados das seções feminina e masculina ao longo do período analisado. Ocorre certa variação no número de alunos do sexo masculino, tendendo à diminuição, e uma altíssima elevação no número de alunas diplomadas ${ }^{41}$. Nos dois últimos anos (18981899) a diferença numérica entre os gêneros é bastante acentuada: o número de mulheres é cerca de quatro vezes superior ao dos homens.

Tabela 1: $\mathrm{N}^{\mathrm{o}}$ de Diplomados nas seções feminina e masculina

\begin{tabular}{|l|r|r|r|}
\hline Ano & Homens & Mulheres & Total \\
\hline 1887 & 36 & 14 & 50 \\
\hline 1894 & 19 & 21 & 40 \\
\hline 1895 & 8 & 15 & 23 \\
\hline 1896 & 4 & 5 & 9 \\
\hline 1897 & 7 & 22 & 29 \\
\hline 1898 & 12 & 52 & 64 \\
\hline 1899 & 16 & 72 & 88 \\
\hline
\end{tabular}

\footnotetext{
${ }^{40} \mathrm{O}$ curso normal, na ausência de opções mais adequadas, servia como ponte para o nível superior, especialmente o bacharelado, o que ocorreu entre os paulistas. Porém, os alunos do Rio de Janeiro tinham, em geral, formação pelo Colégio D. Pedro II. (J.L.Almeida Nogueira. A Academia de São Paulo: Tradições e Reminiscências. SP: Centro Acadêmico, 1956.)

${ }^{41}$ Essa alteração na demanda reflete-se, atualmente, na distinção do alunado dos cursos de Letras e Engenharia (à exceção do curso de Engenharia de Alimentos), sendo este marcadamente masculino, e aquele composto principalmente por mulheres.
} 
A escola promovia, então, a saída das mulheres de suas casas. Primeiramente, para frequentar o curso normal, e depois, para lecionar. As normalistas passavam à conquista do espaço público, ocupando as ruas e o mercado de trabalho; promovia-se a valorização da figura feminina no campo da educação:

Depois que a dignidade feminil foi esboçada pela antiguidade polytheica, depois que foi completada pelo catholicismo medievo, e foi por fim definitivamente systematizada pela philosophia, pela politica positiva, - não ha mais duvidar que á Mulher cabe a instrucção primaria das crianças, não ha mais discutir que das Mães pende a formação em geral dos cidadãos futuros. Systema social em que tal missão fôr menosprezada, é impossivel subsistir, demanda prompta e total regeneração ${ }^{42}$.

Nesse contexto, o discurso sobre educação associava o magistério à atividade materna, o que favoreceu a feminização do curso. Agregavam-se, na figura da professora, o passado dos valores tradicionais e familiares, e o presente, representado nas disciplinas ligadas às ciências modernas e línguas estrangeiras.

No entanto, destaque-se que, a despeito de as mulheres terem encontrado espaço na educação, a direção do sistema educacional continuava em mãos masculinas, visto que as cadeiras da Escola Normal ${ }^{43}$, os cargos de inspetoria da Instrução Pública e cargos políticos ligados à educação e cultura eram assumidos por homens. Em suma, a educação e as instituições surgidas na virada do século encaminharam mulheres e homens para formações e atividades diferentes.

\footnotetext{
42 Discurso do Sr. José Feliciano, professor da Escola Normal, em Rodrigues, 1930:355.

43 À exceção das aulas de Economia Doméstica na seção feminina da ENC, ministradas pela Prof. ${ }^{\mathbf{a}}$ Felicidade Perpétua de Macedo, que também exercia a atividade de inspetora da seção. Note-se também que os registros que analisamos no presente estudo, cartas e atas, foram todos redigidos por homens, professores e diretores da ENC.
} 


\subsubsection{O currículo escolar}

Com relação às disciplinas da Escola Normal oferecidas antes e depois da República, verificamos que a reforma promoveu a especialização dos cursos. O destaque dado à ciência e o refinamento das especializações ocorridos no século XIX resultaram na distinção precisa entre áreas do conhecimento e na prática exagerada da classificação (de animais, plantas, seres humanos...) (Schwarcz, 2007:29). Com variação de três a quatro cadeiras em 1877, conforme o ano do curso, a Escola Normal passa a oferecer, em 1894, em torno de oito cadeiras, variando em função do semestre do curso. No currículo de 1894, constam disciplinas selecionadas por uma visão de mundo e ensino modernizante, verdadeiras pontes para o mundo das civilizações tidas como culturalmente desenvolvidas, integradas pelas línguas estrangeiras francês, alemão, e inglês; e pelos estudos ligados às ciências, como anatomia, história natural, física, química, astronomia, mecânica.

Havia a preocupação, por parte da Escola Normal, de criar a infra-estrutura necessária para o desenvolvimento desses estudos. No livro de correspondências emitidas pela direção da ENC em 1894 registram-se quatro cartas ao Dr. Cesário Motta Jr., Secretário de Estado dos Negócios do Interior, comunicando a compra ou recebimento de materiais de Química, Física, e Ciências Naturais para uso em laboratório, sendo que uma delas mostra-se particularmente interessante. Consiste no registro de compra de "peças de anatomia humana e comparada, e de modelos de fructos e flôres, encommendadas" diretamente da "casa Emile Deyrelle em Paris". ${ }^{4}$

Não bastava somente importar a mentalidade e a ciência, mas a presença de aparato técnico vindo diretamente de Paris intensificava o poder simbólico da Escola

\footnotetext{
${ }^{44}$ Correspondência Oficial (1894), n 38. Acervo Histórico da Escola Caetano de Campos.
} 
como instituição representante da modernidade. Esse efeito provavelmente não impactava a sociedade como um todo, e sim os que estavam envolvidos no cotidiano escolar, como funcionários, alunos, suas famílias, e mesmo a direção e professores da Escola. Afinal, para ser validado, o "cenário" republicano deveria convencer, primeiramente, seus próprios atores.

Apesar de constarem no currículo três línguas estrangeiras, a presença de aulas de português ao longo de todo o curso e a inserção de certas disciplinas no currículo, conforme observamos nos programas de ensino para o ano de $1895^{45}$, indiciam uma tentativa de valorização e aprofundamento da questão da identidade nacional. A língua, elemento fundamental de identidade de um povo e "uma das manifestações mais importantes da identidade coletiva" (Burke, 1995: 94), passa a ser privilegiada no novo programa. É criado o curso de História da língua portuguesa, e as aulas de Português passam a ser oferecidas em todos os semestres, diferentemente do que ocorria antes da reforma e também com relação às línguas estrangeiras. São criadas as disciplinas Geografia do Brasil, História do Brasil, também vinculadas à questão nacional. A estas, seguindo tendência positivista disciplinadora e de construção da cidadania, somam-se as aulas de Educação Cívica.

No período em estudo, as questões de saúde pública e o desenvolvimento da medicina levaram a uma maior preocupação com a saúde do corpo, o que se refletiu na implantação de aulas de ginástica, e na compra de materiais para esse curso, registrada também em cartas da Diretoria. Para os rapazes, havia também aulas de exercícios militares, manifestação da disciplina positivista.

Mas, nesse moderno currículo, que é simultaneamente nacional e europeu, há um constituinte dissonante. À exceção de uma, as disciplinas eram as mesmas para as

\footnotetext{
${ }^{45}$ Atas da Congregação (1895). Acervo Histórico da Escola Caetano de Campos.
} 
seções feminina e masculina da Escola Normal. No $1^{\circ}$ e $4^{\circ}$ ano, distinguiam-se para esses grupos, respectivamente, as aulas de trabalhos manuais e economia doméstica; e escrituração mercantil e economia política. Essa diferença na constituição do programa não somente preparava o educando para o exercício de determinada atividade, mas consolidava diferentes lugares sociais para cada gênero. Aos rapazes, a vida pública, representada pela política e o comércio; e para as moças, o ambiente privado do lar e a vida doméstica.

\subsubsection{O espaço da Língua Portuguesa no currículo da ENC}

Os registros dos conteúdos ministrados na ENC são esparsos e pouco detalhados. Nossas verificações sobre o currículo do curso têm se baseado principalmente em dados do Relatório apresentado pelo diretor Gabriel Prestes ao Governo do Estado, no qual consta o programa de ensino do ano de 1896; e os registrados nas atas da Congregação de anos diversos, nas quais se encontram o quadro de disciplinas ministradas e pontos para exame finais e para concurso, além de obras adotadas para o ensino.

No que se refere ao ensino da língua nacional, observamos um esforço de promover inovação ainda na fase monárquica da Escola Normal, empreendido por Silva Jardim. Em oposição à tradição de ensino, o docente buscou priorizar a literatura e a abordagem de textos em detrimento de questões estritamente gramaticais, incentivando o potencial criativo dos alunos: 
Afastando-se da velha rotina que fazia dos professores do pátrio idioma meros repetidores do texto dos compêndios e dos estudantes recipientes passivos dum ensino sem originalidade, o Dr. Silva Jardim queria que os seus alumnos puzessem de lado as preoccupações da grammatiquice estéril e concentrassem o melhor do seu esfôrço em ensaios de producção litteraria. Como meios para isso elle introduziu em suas aulas diversas industrias inéditas, taes como a leitura do noticiário dos jornaes feita pelos alumnos e seguida do respectivo commentario; os exercícios de locução e leitura expressiva; a interpretação do texto lido, com a apreciação das bellezas litterarias nelle contidas. (Rodrigues, 1930: 122)

Com um novo enfoque nas questões abordadas em aula e utilizando-se de nova metodologia, a proposta de Silva Jardim causou estranhamento entre os alunos, sendo posteriormente bem aceita. Esse choque inicial não deixa dúvidas sobre o aspecto inovador da atuação do docente, e exemplifica a resistência própria a situações de mudança, em particular, as de ordem cultural.

No começo, como era de esperar, esses processos causaram certa confusão e desanimo: - era muito mais fácil seguir a rota batida dos exercícios de analyse grammatical e lógica. [...] Felizmente durou pouco esse estado de hesitação. Os benefícios da nova orientação fizeram-se sentir desde logo e tiveram por effeito despertar o enthusiasmo e a emulação dos alumnos. Para o fim de melhor auxilial-os, o novo cathedratico publicou, tempos depois, um folheto sobre o ensino da língua materna, trabalho em que assentava definitivamente as directrizes do seu methodo. Esse trabalho teve larga divulgação e a edição de prompto se esgotou, não sendo infelizmente seguida de outra. (Rodrigues, 1930: 122) 
As novidades implementadas por Silva Jardim não se restringiram ao âmbito da ENC, mas alcançaram repercussão externa, influenciando até mesmo os processos didáticos de alfabetização (cf. Rodrigues, 1930). Porém, a atuação do docente na instituição foi interrompida, em 1886, por conta de conflitos ideológicos, sendo então sucedido por Julio Ribeiro, consagrado autor da língua portuguesa.

O novo lente era reconhecido como gramático, endossava as inovações implementadas por Silva Jardim e recomendava a leitura de "bons autores" como "meio de apurar o estilo e desenvolver o gosto literário". A despeito de apresentar essas qualidades, Julio Ribeiro não conseguia, na prática, obter entre os alunos o mesmo sucesso que o lente anterior, pois sua didática estava ligada ao modelo tradicional de preleções, já condenado pelas novas orientações do ensino (Rodrigues, 1930: 144-145).

Os registros a partir desse período não trazem notícia das práticas de sala de aula, indicando apenas os conteúdos priorizados nas disciplinas e os livros tomados para análise. No ano de $1887^{46}$, são citadas como referência no programa de ensino as obras A vida do Padre Antonio Vieira, de João Francisco Lisboa, e o clássico português $O s$ Lusíadas, de Luiz de Camões. Nesse período, a vinculação política oficial com Portugal já havia sido desfeita, mas havia ainda certo elo linguístico e cultural, representado pelas obras eleitas para estudo, que remetia ao período clássico.

A despeito de serem trabalhados somente elementos gramaticais nos textos literários, percebemos a importância de sua seleção em detrimento de outras obras. Sendo "a literatura um ritual complexo que, se devidamente conduzido, tem o poder de construir e modelar simbolicamente o mundo", a eleição de textos vinculados a Portugal, num momento em que a Escola está sob uma direção rígida, tradicional e coercitiva, representava uma forma de reação à modernidade, uma forma de promover

\footnotetext{
${ }^{46}$ Nesse ano, a primeira cadeira é assumida pelo Dr. Carlos Reis.
} 
mais do que a simples divulgação de ideias, mas criar "estados de espírito, despertar ou ensejar desígnios éticos” (Sevcenko, 1995: 233) ligados a valores do passado.

Já nos primeiros anos republicanos o ensino de língua portuguesa na instituição manteve elementos tradicionais, exemplificados pela adoção de Os Lusíadas como ponto para ensino e exames dos alunos e para concurso de professores, bem como a inserção, entre os materiais para exames, da obra A Republica e a Monarchia, do autor português Latino Coelho ${ }^{47}$.

O ensino de língua desenvolvia-se, também, a partir de textos modelares apresentados em seleta pelo também português Caldas Aulete ${ }^{48}$, dos quais são adotados os volumes de Poesia e Litteratura. Ambos apresentam principalmente textos de autores portugueses, mas cerca de um quarto do total corresponde a autores brasileiros. Há uma notável diferença no período de produção dos textos quando comparados os dois volumes da obra. Enquanto o de Poesia privilegia textos dos séculos XVIII e XIX, o de Litteratura oferece espaço, ao lado das produções desse período, a outras, quinhentistas e seiscentistas ${ }^{49}$.

Ainda nesse período, constatamos a adoção da Grammatica Portugueza, de Julio Ribeiro, registrada em $1890^{50}$. Apesar do insucesso do gramático como professor devido a sua didática ultrapassada (cf. Rodrigues, 1930), sua obra era considerada moderna e inovadora por abordar questões e concepções linguísticas sob um ponto de vista pautado

\footnotetext{
${ }^{47} \mathrm{O}$ autor Latino Coelho, político, militar e escritor filiado ao republicanismo (moderado), tem no currículo livros sobre história de Portugal e biografias de personalidades portuguesas. Não encontramos informações sobre a obra A Republica e a Monarchia, nem ao menos registro de sua existência.

${ }^{48}$ Ata da Congregação, 20 de março de 1890.

${ }^{49}$ Observe-se que essas obras constam como base para os exames finais de 1890, primeiro ano em que a Escola esteve sob a direção republicana. Não encontramos, à exceção de Os Luziadas, registro de uso dessas obras em data posterior - o que não implica necessariamente no fato de que não tenham mais sido utilizadas.

${ }^{50}$ É possível, e diríamos que até provável, que a Gramática de Julio Ribeiro fosse adotada há mais tempo na Escola Normal, dado o prestígio do autor e sua presença como professor na ENC em 1886. Ressaltamos, porém, que a data de 1890 é a do primeiro documento que encontramos em que se registra a adoção da obra como referencial de gramática na Escola, o que não anula a hipótese de que já fosse usada antes desse momento na instituição.
} 
nas mentalidades e correntes mais atuais da época. A adesão a essas ideias reflete-se em sua visão evolucionista sobre o fenômeno de mudança no português do Brasil:

Não é por se não fazer estudo dos modelos legítimos e castiços, não é por se lerem muito os livros francezes que se vai transformando a língua portugueza; nem tal transformação é vergonhosa ou prejudicial. Producto inevitavel, necessario, fatal, da evolução linguistica, ella accusa nova phase do modo de pensar, accusa desenvolvimento do cérebro, accusa progresso da humanidade. (Ribeiro, 1914: 325, grifo nosso).

O trecho traz implícito o calor das discussões sobre língua nacional e a questão identitária que marcaram o período de publicação da Gramática, cuja primeira edição foi lançada em 1881.

Os exames finais de $1890^{51}$ consistem, basicamente, na aplicação de questões gramaticais a trechos selecionados das obras acima referidas (as Selectas de Aulete, Os Luziadas de Camões, A Republica e a Monarchia de Latino Coelho). Os concursos de 1894 e 1898 seguem o mesmo processo, distinguindo-se porém as questões e as obras para aplicação dos pontos (Os Luziadas, de Camões, e os clássicos Eneida e Iliada ${ }^{52}$ ).

A análise dos pontos para exames $(1890)$ e concursos $(1894,1898)$ aponta um maior enfoque em questões gramaticais em detrimento de uma abordagem voltada para o texto ou para a história da língua. Apesar dessa tendência, observamos, no conteúdo das provas dos concursos, discussões e reflexões linguísticas um pouco mais amplas ${ }^{53}$. Sinalizando a valorização das raízes da língua e da tradição clássica, há questões

\footnotetext{
${ }_{52}^{51}$ Atas da Congregação, 18 de Novembro de 1890.

${ }^{52}$ É interessante que a Eneida e a Ilíada tenham sido, pelo menos até 1898 (data do último registro consultado), referenciais nos exames de língua portuguesa, visto se tratarem de obras traduzidas.

${ }^{53}$ Vale lembrar que, nesse momento, o currículo de língua nacional oferecia aulas de 'Português' e 'História da Língua', variáveis conforme o semestre do curso.
} 
referentes à história do português e certo enfoque no século XVI, aspectos exemplificados pelas seguintes questões:

- Theoria da linguagem e formação da lingua portugueza

- O Portuguez no século XVI, suas alterações phoneticas, morphologicas e syntacticas $^{54}$

-Historia da língua. Causas do engrandecimento da lingua portugueza no sec. XVI. Principaes monumentos e autores dessa epocha. ${ }^{55}$

Mas nem só no passado da língua se pautavam os programas dos concursos. Em convergência com as preocupações identitárias da época, notam-se vestígios da discussão sobre a língua e a literatura do século XIX e suas tendências mais atuais:

- Literatura. O Romantismo e suas causas mais geraes. Seus principaes oradores em Portugal e no Brasil ${ }^{56}$

- Tendencias hodiernas para alteração do idioma nacional ${ }^{57}$

Vale destacar que, ainda que sejam em pequeno número, esses elementos indiciam a valorização de elementos locais, representados pelo movimento literário romântico, que, apesar de abordar de forma 'problemática' o tema nacional ${ }^{58}$, consistiu numa importante iniciativa nesse sentido. Além disso, faz-se referência a autores brasileiros do período, o que também evidencia certo anseio por elementos da cultura nacional. O segundo tópico parece relacionar-se à questão da mudança linguística, revelando um posicionamento de aceitação das inovações nesse âmbito ${ }^{59}$.

\footnotetext{
${ }_{55}$ Atas da Congregação, 14 de Março de 1898.

55 Atas da Congregação, 5 de Abril de 1894.

${ }^{56}$ Atas da Congregação, 14 de Março de 1898.

${ }^{57}$ Atas da Congregação, 5 de Abril de 1894.

${ }^{58}$ Com um enfoque exagerado e idealizado do indígena, por exemplo.

${ }^{59}$ Posicionamento compartilhado por Julio Ribeiro (1914: 325).
} 
Porém, nem só com literatura se faziam as aulas na ENC. Em 1896, apesar de se registrar para o $2^{\circ}$ ano a análise literária e sintática d'Os Lusíadas, não há referência ao uso de textos literários nos outros anos do curso, e nem de outras obras além do clássico camoniano. O restante do programa baseia-se principalmente em questões gramaticais para o $1^{\circ}$ e $2^{\circ}$ anos, e na história da língua para o $3^{\circ}$ (por meio dos conteúdos “classificação das línguas" e "alteração das línguas" ${ }^{60}$ ). Contudo destaca-se, no $1^{\circ}$ ano, além da redação de "composições", a prática de uma escrita mais formal como a que analisaremos na seção III deste trabalho, representada por requerimentos, ofícios e cartas. Nesse período, o $4^{\circ}$ ano não tinha aulas de língua nacional.

Apesar de não ser possível fazer grandes inferências sobre o ensino e as concepções de língua na instituição a partir dos registros relacionados à língua portuguesa na ENC, os documentos analisados sinalizam aspectos importantes ligados ao ensino e aos valores culturais referentes à língua e identidade(s) que permeavam as mentalidades 'à frente da locomotiva' da Escola Normal. Conjugavam-se principalmente dois elementos: a língua do período quinhentista, representada sobretudo pela obra Os Luziadas; e o reconhecimento da necessidade ou existência de certa autonomia linguística do Brasil em relação a Portugal, indiciada pela adoção da Gramática de Julio Ribeiro e pela valorização do movimento literário Romantismo e seus autores nacionais.

\footnotetext{
${ }^{60}$ A prática da classificação e o olhar evolucionista frequentemente identificados nos estudos de biologia e antropologia no século XIX, relacionados a animais, plantas, seres humanos, povos, etc., estendiam-se também a outros elementos, como as línguas, concebidas como organismos vivos.
} 


\subsection{A 'missão' da Escola Normal da Capital: os trilhos do progresso e a ferrugem nas engrenagens}

A partir do levantamento e análise de diversos aspectos da Escola Normal da Capital no final do século XIX, observamos a forte tendência da instituição ao conservadorismo. A despeito disso, verificamos que se ensaiaram nesse momento os primeiros passos que levaram a mudanças sociais e ligadas ao ensino público, tais como a profissionalização do magistério, a inserção da mulher no mercado de trabalho (porém restrita ao ensino primário ou de disciplinas 'femininas', como economia doméstica), além da criação de um grupo identitário na área da educação, representado pela figura do normalista, que passaria a exercer a docência e gestão da ENC.

Destacamos ainda a importância da relação entre a Escola Normal, a Academia de Direito e o Instituto Histórico e Geográfico de São Paulo ${ }^{61}$, instituições que, ao lado do Museu Paulista, compunham os alicerces da intelectualidade paulista no que se refere a sua formação e atuação. Os paradoxos resultantes da tensão entre o novo e o velho, intrínsecos a essas instituições, repercutirão na ENC, que se constituía sob um discurso modernizante que pregava a renovação da sociedade por meio da apologia da instrução, da razão e da ciência, e sofria, ao mesmo tempo, a intensa atuação de forças conservadoras.

Provavelmente, no contexto analisado, o principal elemento de conservação seja a dificuldade em se empreender ações que tivessem resultado efetivo no ensino público. Parece-nos que, numa atitude radical $^{62}$, a República, sob a fachada de reforma da

\footnotetext{
${ }^{61}$ Representado pelos professores Carlos Reis, membro do IHGSP e Vieira de Almeida, colaborador na Revista do Instituto; pelo Secretário do Estado de Negócios do Interior Cesário Motta Jr., a quem a direção da Escola estava submetida e com quem mantinha comunicação frequente e direta; e o presidente da província Prudente de Morais, presidente honorário do IHGSP e importante figura da reforma republicana na Instrução Pública.

${ }^{62}$ Segundo a concepção de Cândido, 1988.
} 
instrução pública, garantiu o acesso à instrução pública de nível secundário especialmente à camada média da população (grupo identificado com o regime), e a acomodação das hierarquias sociais, econômicas e culturais, por meio da manutenção das estruturas vigentes.

\subsection{Ordem de constituintes e estilo: a questão da inversão}

Em fins do século XIX muito se discutia sobre a correção da língua, sobre o que era certo ou errado. Tais discussões se justificam se considerarmos que, além do rompimento com Portugal, representado pelo fim da Monarquia, houve no século XIX intensa imigração para o Brasil. Assim, num contexto de afastamento da oficialidade da cultura e língua do colonizador, agora estrangeiro, e com a chegada de outras línguas trazidas pelos imigrantes, as polêmicas acerca da língua local ${ }^{63}$ e sua preservação se tornaram crescentes.

Somavam-se a esse quadro as teorias evolucionistas, postulando a mudança como caminho obrigatório e natural dos povos e elementos de sua cultura. De fato, a diversidade social e cultural favoreceu uma série de mudanças linguísticas que ocorriam nesse momento e que definiriam uma gramática do Português Brasileiro na passagem do século XIX para o XX (Tarallo, 1993).

\footnotetext{
${ }^{63}$ Exemplo disto, entre vários outros documentos sobre o assunto, é o discurso A língua materna, proferido pelo deputado Sr. Dr. Fontes Junior defendendo o ensino de língua portuguesa nas escolas estrangeiras em São Paulo. O texto pode ser consultado na Revista Eschola Publica, Ano 1 n. ${ }^{\circ}$ 4, 1896.
} 


\subsubsection{A ordem em foco: o olhar dos (e sobre os) gramáticos}

O período a que remete este estudo, por conta da variação que caracterizou as mudanças linguísticas que então se processavam, foi palco de inúmeras polêmicas. Abrangendo especialmente questões lexicais, chegaram também a aspectos sintáticos, como a colocação pronominal, muito debatida, sem deixar de fora a questão da ordem de constituintes. A preferência pela ordem com sujeito realizado antes do verbo, ainda que não estigmatizada, era uma característica inovadora da língua, do PB que se delineava naquele período - ou que se delineara recentemente. No entanto, muitos preferiam a ordem frequentemente designada como indireta, ou invertida, marca de distinção representada na sintaxe.

A respeito dessa questão, os gramáticos da época assumiam postura não estigmatizante da ordem SV, porém destacavam a tônica estilística da estrutura com inversão. Em geral, a ordem invertida, por alguns classificada como figurada, era interpretada como sendo distinta da ordem lógica das ideias. Por este motivo, é analisada como tendo maior energia de expressão que a ordem direta (Julio Cesar Ribeiro, $1914[1881]^{64}$ ), e associada às paixões e aos sentimentos (Eduardo Carlos Pereira, $\left.1907^{65}\right)$.

As inversões poderiam se referir não somente à sequência verbo-sujeito, como à ordem de orações (subordinada-principal), ou ainda à inversão complemento-verbo. O estilo diferenciado, o "algo a mais" por elas trazido não era visto com bons olhos em qualquer situação. Em polêmica sobre questões gramaticais, José Veríssimo discute posicionamentos e usos da língua realizados por Carneiro Ribeiro e Ruy Barbosa. Nesse

\footnotetext{
${ }^{64}$ RIBEIRO, Julio C. (1914). Grammatica Portugueza. 12a ed. Rio de Janeiro: Francisco Alves.

${ }^{65}$ PEREIRA, Eduardo Carlos (1907). Grammatica Expositiva. SP: Weiszflog Irmãos \& Co.
} 
texto, o autor critica o uso de recursos linguísticos com o intuito de copiar o português quinhentista, ou o clássico.

[...] Como todo purista que se preza, tem o Dr. Rui Barbosa o gôsto, que a mim me parece literàriamente mau, e até malsão, de rebuscar nos autores clássicos, pouco lidos, e nos velhos vocabulários da língua, têrmos obsoletos, expressões arcaicas, palavras inteiramente desusadas ou escassamente usadas, para darem à sua linguagem aparências $e$ feições de clássica. Como, apesar de qualquer esforço, é impossível a um escritor de hoje escrever em tudo e por tudo conforme um quinhentista, o que é o mais seguro e decisivo argumento a favor da evolução da língua, e por outro lado, é relativamente fácil afetar classicismo empregando aquêles vocábulos e um ou outro fraseado obsoleto, a êsse meio recorrem os puristas, ou que o pretendem ser, para nos darem a ilusão de que são dignos de emparelhar com os clássicos. Um conheço eи que usa desta simples receita: pôr sempre o verbo, ou o seu adjunto, no princípio da frase: Lícito não é. Forçoso me fora. Gostara muitíssimo: outros catam nos dicionários os termos que levam adiante a notação ant. (antiquado) fazem dele listas, a que recorrem para salpicar seu estilo de vocábulos raros, sem verem o disparate resultante do enxêrto numa frase moderna pelo seu boleio e até pela idéia que exprime de um têrmo antiquado. (Veríssimo, 1969 [1902]:116, grifo nosso)

A imitação a que Veríssimo se refere, concretizada não somente nas inversões como em outros recursos, objetiva dar ao leitor a ilusão de que seus autores são dignos de emparelhar com os clássicos (idem: 413). Contudo, o autor demonstra apreciação pelo clássico, enfocando sua crítica na adoção imprópria e superficial das características desse estilo linguístico. 
Os que de fato lêem e estudam os clássicos são raríssimos, e mais raros ainda os que dêles aproveitam com discernimento, bom gosto e bem logrado proveito. (Idem:413)

Em sua disposição final acima transcrita, sequência do trecho anterior, Veríssimo reconhece e valoriza o clássico e aqueles que dele fazem 'bom uso'. Provavelmente, sem essa ressalva sua própria autoridade intelectual seria posta em xeque.

\subsubsection{A ordem de constituintes no currículo escolar}

A despeito do emprego exagerado de inversões ser considerado um artificialismo próprio de quem não domina, realmente, a linguagem culta dos clássicos, os registros acima transcritos, bem como o trecho do romance de Lima Barreto constante na epígrafe deste estudo, apresentam a inversão como recurso estilístico da língua ligado a uma tradição letrada. Resultado do afastamento da linguagem mais comum, consiste numa marca de distinção social e cultural.

A escola, organismo reprodutor de cultura e hierarquias sociais, operava também sobre os aspectos linguísticos no que se refere a preparar os alunos para um uso distinto da língua. Analisando o programa da Escola Modelo Caetano de Campos, na qual os alunos da ENC realizavam suas práticas de ensino, verificamos constar do programa das aulas de Linguagem o exercício da inversão, conforme se pode observar no trecho destacado abaixo. 


\section{Linguagem}

Especificação dos exercícios: Leitura e interpretação de um pequeno trecho para servir de thema aos exercicios escriptos. Dictado; Synonymia. Transformação do trecho lido pela substituição das palavras indicadas pelo professor. Transformação de estylo modificando-se as sentenças quanto á significação, quanto á ordem dos seus elementos ou quanto á voz do verbo. $1^{\circ}$ oralmente. $2^{\circ}$ por escripto. Transformação do verso para prosa. Composição livre. (Prestes, Gabriel (1896). Relatório ao Governo do Estado de São Paulo, p. 151, grifo nosso)

O ponto compunha o currículo do $4^{\circ}$ e $5^{\circ}$ anos das seções feminina e masculina da Escola, ou seja, era ministrado aos alunos em estágio mais avançado no percurso escolar. É interessante observar que o exercício em questão deveria ser realizado primeiro oralmente, e depois por escrito. Este fato pode ser devido à importância da retórica no período e mais ainda nessa Escola, que a tinha intensificada por um caráter fortemente bacharelesco, conforme mostramos em seção anterior.

A presença da ordem dos elementos da sentença no conteúdo programático reforça o papel da escola como instrumento consagrador de distinções ao treinar seus alunos na prática de uma modalidade linguística culta baseada em modelo anacrônico do ponto de vista do uso coloquial. Ao mesmo tempo, evidencia o fato de ordens diferentes apresentarem valores sociais diferentes, e reforça o caráter distintivo das ordens menos 'naturais', cuja produção é artificial posto que voluntária e motivada por instrução do professor.

A ação pedagógica transmite, assim, não apenas o conteúdo em si, mas a afirmação do valor deste conteúdo (Bourdieu, 2009:257). Deste modo, a aplicação contínua dessa metodologia pode proporcionar a criação de um habitus linguístico por permitir não apenas o reconhecimento de uma variedade culta, a inversão, mas por 
induzir à sua prática, isto é, levando o aluno a conhecê-la ao habilitá-lo a empregar essa variedade (Ortiz, 2003:162). Embora esse uso ocorra, num primeiro momento, de forma consciente, a sistematização dessa prática tende a produzir a assimilação da forma social e culturalmente distinta pelos alunos, que vão reforçar um habitus adquirido no meio familiar, ou adaptar o habitus com o qual ingressaram na escola ${ }^{66}$. Associada a práticas em outros âmbitos que não o linguístico, visa preparar o aluno para se inserir em ambientes sócio-culturais específicos.

${ }^{66}$ Uma terceira alternativa nesta situação é a de exclusão do aluno do sistema de ensino devido às dificuldades na assimilação do habitus, por não se sentir inserido no ambiente ou devido a reprovações. 


\section{Capítulo 2}

\section{A Posição do Sujeito: colocando a questão nos trilhos}

Alguns esclarecimentos teóricos se fazem necessários para que se possa ter uma melhor compreensão diacrônica do fenômeno linguístico em estudo ${ }^{67}$. O conjunto de pressupostos aqui assumidos ${ }^{68}$, referente à teoria gerativa, fundamenta-se no caráter inato da aquisição de língua. Segundo essa perspectiva, cada indivíduo nasce com o aparato mental necessário para desenvolver e definir uma gramática ${ }^{69}$, o que ocorre a partir do contato com dados de uma determinada língua (input).

Essa vertente teórica baseia-se na ideia de que o simples contato com uma língua não é suficiente para que uma criança venha a adquiri-la. Esse fenômeno requer um aparato mental prévio, que processe os dados do input e gere uma gramática, de certo modo correspondente à da língua à qual a criança está exposta. Por ser essa gramática uma predisposição biológica, seu estágio inicial, anterior à interferência de dados linguísticos, é comum a todo indivíduo, sendo por esta razão chamado de Gramática Universal (GU). Compõe-se de leis gerais, ou Princípios, comuns a todas as línguas; e de Parâmetros, características específicas que diferenciam uma língua das outras.

O fato de a gramática ser, em princípio, processada mentalmente, implica em uma relação entre o material linguístico produzido na mente do falante e o que é emitido por ele, caracterizando um processo que vai do interior para o exterior. Essa relação torna-se mais clara quando comparada ao processamento de informações em um sistema

\footnotetext{
67 Explicitaremos aqui conceitos da teoria gerativa como suporte para a revisão bibliográfica que realizaremos neste capítulo. Contudo, não a utilizaremos como ferramenta para análise dos dados.

${ }^{68}$ Baseados em Chomsky 1981, 1986.

${ }^{69} \mathrm{O}$ conceito de gramática que assumimos não é o padrão de correção e norma culta, ligada à Gramática Tradicional (GT), e sim o conjunto de regras que orientam o uso efetivo da língua, a qual opera na mente de cada falante e é externada em sua fala/escrita.
} 
computacional. Um incontável número de pessoas já passou pela experiência de, ao abrir um arquivo de computador em programa inadequado, se deparar com uma série de símbolos ininteligíveis ao invés de encontrar o texto ou outro documento que esperava. Ainda que, para leigos em programação, aqueles códigos não signifiquem nada, para o ‘cérebro' do computador eles são compreensíveis. Para que o usuário possa compreender a informação ali codificada, ela é representada numa outra linguagem, mais acessível à percepção humana, na forma de texto, planilha, etc.

Analogamente, podemos conceber a língua que externamos como um documento acessado no computador. Assim como o arquivo ali apresentado, a produção linguística de um falante resulta de estruturas e operações localizadas e ocorridas mentalmente, as quais codificam a expressão numa forma compreensível à percepção visual e/ou auditiva de seu interlocutor. A essa língua externa, espécie de tradução feita para tornar possível o acesso humano, denomina-se Língua-E. Ao construto mental da língua, de caráter interno e somente acessível e compreensível ao sistema cognitivo, chama-se Língua-I.

A análise de viés gerativista busca, a partir das pistas fornecidas pela Língua-E (i.e., pela escrita e principalmente pela fala), identificar as estruturas e mecanismos da produção linguística em nível mental, relacionados ao funcionamento do 'sistema computacional' responsável pelo processamento das línguas humanas. Para isso, tomará como objeto de análise a sentença, cuja estrutura é, mentalmente, hierárquica, porém interpretada e externada de forma linear devido a restrições articulatórias e perceptuais. 


\subsection{Representação das sentenças: a posição do sujeito}

Para representar a estrutura hierárquica da gramática (Língua-I), adotou-se o mecanismo da representação arbórea. Tomando-se o conceito binário de sintagma, a ramificação da árvore é sempre bifurcada. Suas ramificações, também chamadas de projeções, são ocupadas por elementos com diferentes estatutos no interior do sistema, o que determinará a forma como se distribuem na árvore. As relações entre as estruturas linguísticas se estabelecem a partir de núcleos que podem se ligar a outras categorias, como especificador (spec) e complemento (comp), para satisfazer sua estrutura argumental, de acordo com a seguinte configuração:

(I)

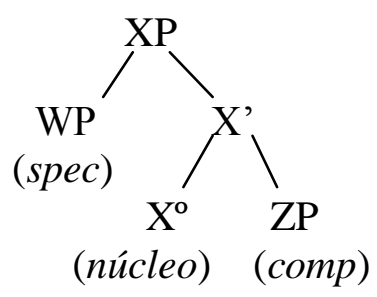

Essa relação se estabelece entre os chamados predicadores, núcleos que abrem 'espaços' que precisam ser saturados, e os constituintes que irão preenchê-los, denominados argumentos. Exemplo disto se tem no processamento de sentenças com o verbo encontrar, que seleciona dois argumentos: um especificador (quem encontra) e um complemento (o que é encontrado). O não-preenchimento desses espaços argumentais faz com que uma sentença como (1b) seja agramatical no Português Brasileiro (PB), diferentemente do que ocorre com o predicado saturado em (1a):

(1a) A formiga encontrou a folha. 
(1b) * A formiga encontrou. ${ }^{70}$

Os constituintes da sentença (1a) seriam gerados na árvore em projeções específicas $^{71}$. O verbo surge como núcleo do Sintagma Verbal, tendo à esquerda a posição de especificador, que hospeda o argumento externo; e, à direita, o complemento, ou argumento interno.

(II)

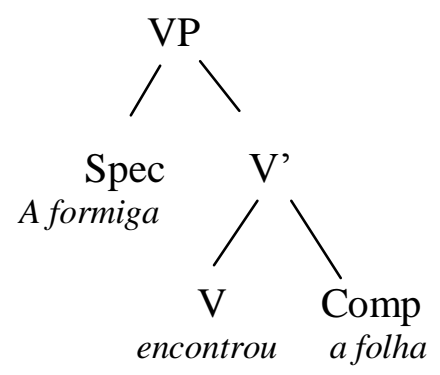

Essa configuração (II) resume-se ao predicador verbal e seus argumentos, mas ainda não estão em jogo as funções sintáticas. Assim, por exigências do sistema, alguns desses elementos precisam se mover para outras posições ${ }^{72}$, configurando então a estrutura sentencial com suas funções sintáticas:

\footnotetext{
${ }^{70} \mathrm{O}$ asterisco no início da sentença indica que ela é agramatical, i.e., não é possível na língua. Essa análise considera uma situação em que o argumento a folha não esteja implícito no discurso, o que tornaria a sentença aceitável.

${ }^{71}$ As siglas correntemente adotadas para nomear esses núcleos correspondem ao inglês Inflectional Phrase (IP) e Verbal Phrase (VP). Posteriormente, apresentaremos também o CP, de Complementizer Phrase.

${ }^{72}$ As posições de onde saiu e por onde passou uma estrutura na árvore são indicadas com a letra $t$ (de 'traço', ou vestígio). A estrutura movida e o traço são marcados com um índice, facilitando a visualização do trajeto dos elementos linguísticos no processo de formação da sentença.
} 
(III)

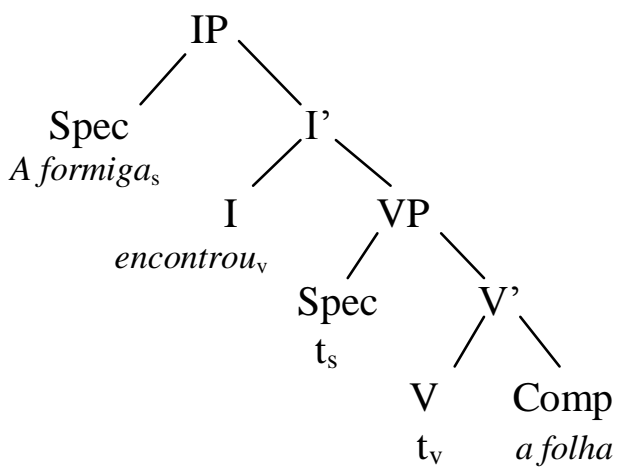

O verbo encontrar, gerado em VP, sem flexão, deve ir para IP, sintagma flexional, para unir-se ao afixo -ou. O argumento externo, por sua vez, precisa mover-se para a posição de especificador do sintagma flexional para recebimento de Caso Nominativo e para entrar em concordância com o verbo. Nessa posição, o argumento ganha o estatuto sintático de sujeito.

Considerando então a distribuição do verbo e seus argumentos na estrutura hierárquica, temos que a ordem posterior à realização dos movimentos gerou um padrão SVO, atestado como a ordem preferencial no PB atual. Assume-se, porém, que essa forma de organização não é absoluta, podendo variar entre as línguas e ao longo do tempo.

No caso de verbos inacusativos, há uma pequena diferença em relação a esse padrão estrutural. Considera-se que esses verbos não apresentam argumento externo, somente o interno. Nesses contextos, para que se configure a ordem SV, o argumento interno, gerado como complemento de VP, deve se mover. Por este motivo, estes verbos são favorecedores da ordem verbo-sujeito, pois, não havendo motivação para a subida do argumento, mantém-se a estrutura original VS.

Estudos diacrônicos sobre o português apontam que, no passado, o verbo ocorria preferencialmente em segunda posição na sentença (Ribeiro, 1995; Torres Morais, 
1993). A primeira posição podia ser preenchida por elementos diversos, de natureza adverbial (2a), argumental (sujeito ou objeto (2b, 2c)), e outros; e a segunda posição alocava o verbo, daí chamar-se esse tipo de estrutura V2.

(2a) Aqui comeu o homem. (XVS)

(2b) O homem comeu a maçã. (SVO)

(2c) A maçã comeu o homem. (OVS)

A realização de sentenças como as em (2), típicas de um estágio do português anterior ao atual, exigia a projeção de mais um núcleo funcional, o $\mathrm{CP}$, acima do sintagma flexional IP. Nessa posição alta iriam se alocar o constituinte inicial da sentença e o verbo ${ }^{73}$, que subia mais um andar:

\section{(IV) OVS}

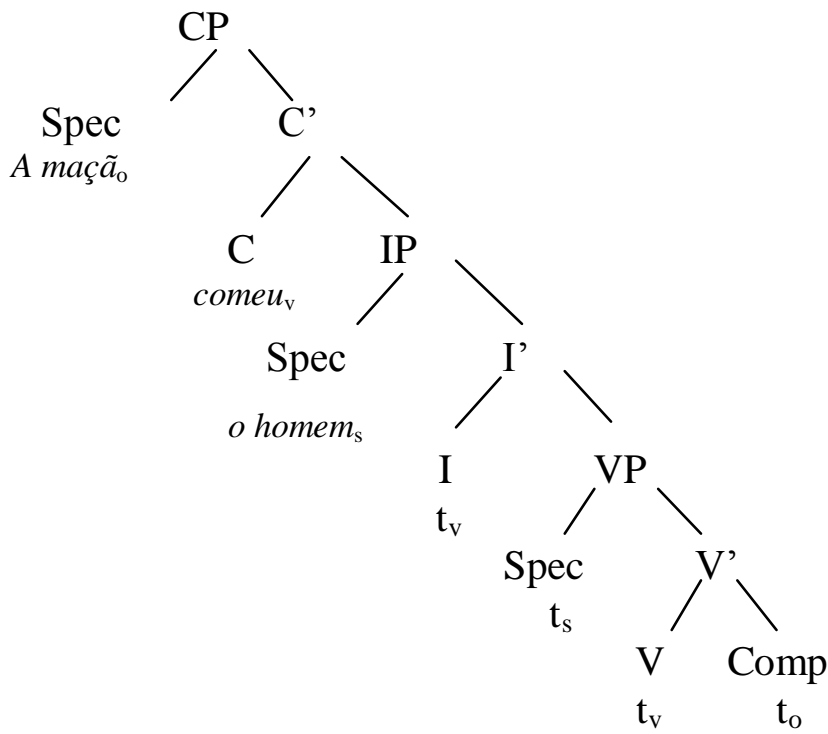

\footnotetext{
${ }^{73} \mathrm{O}$ constituinte inicial pode ser um advérbio, sujeito ou objeto.
} 
(V) SVO

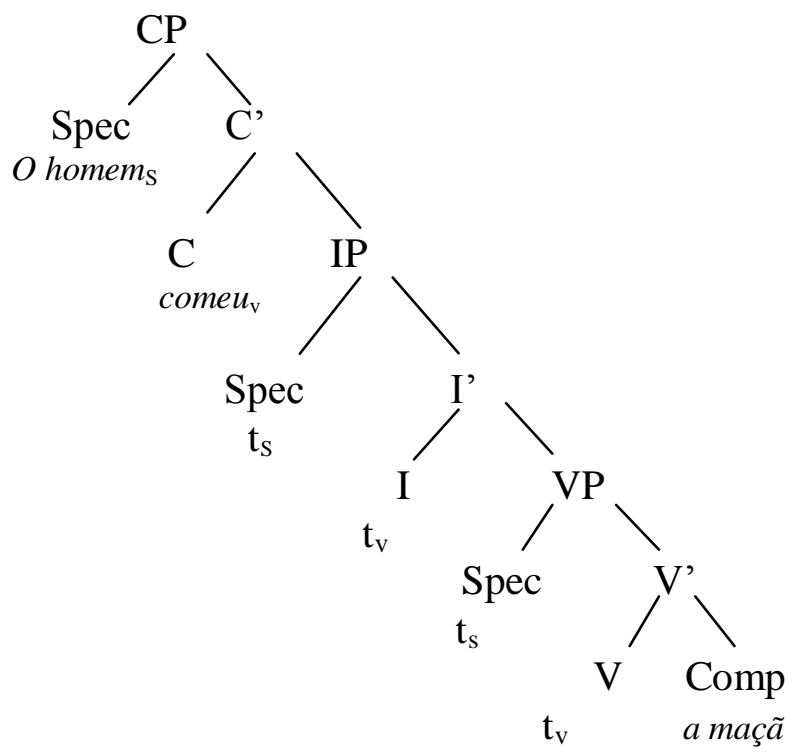

Nas línguas V2, em que a ordem preferencial é XV, o movimento do verbo ocorria obrigatoriamente para C. Do mesmo modo, em sentenças com ordem SV do português arcaico e clássico ${ }^{74}$ representada em (V), o sujeito saía de sua posição natural, especificador de IP, e ia para o especificador de CP para configurar a estrutura V2. Línguas não-V2 não exigem que o $\mathrm{CP}$ seja projetado visto que os constituintes se distribuem entre IP e VP, em sentenças como as esquematizadas (III).

Tais observações revelam que uma sentença SVO qualquer, como a de (3),

(3) O homem comeu a maçã

expressão da Língua-E, externa, pode ser produto de diferentes estruturas mentais (como as representadas em (III) e (V)). Ademais, por meio de exemplos acerca das diferentes formas pelas quais se estruturava a ordem de constituintes no português ao longo dos séculos, vimos que a gramática não é estática, mas sujeita a mudança, o que justifica e confirma a variedade das línguas humanas e sua variação interna.

\footnotetext{
74 Torres Morais (1995) registra o caráter V2 no português até o século XVIII.
} 


\subsection{A posição do sujeito sentencial: caminhos trilhados}

Diversos trabalhos (Pontes, 1987; Berlinck, 1989; Tarallo \& Kato, 2006; entre outros) já abordaram a questão da ordem de constituintes sentenciais no PB. Tomaremos como suporte para nossa análise as hipóteses e resultados apresentados por alguns estudos, sincrônicos e diacrônicos, baseados em linhas teóricas diversas, buscando na multiplicidade de perspectivas maiores contribuições para a interpretação do material analisado.

Dentre os trabalhos levantados citamos o de Pontes (1987), estudo sincrônico feito a partir de textos de revistas e registros de fala informal atuais. Seguindo a linha funcionalista de Givón (1979 apud Pontes, 1987), a autora analisa dados do PB do final do século XX, e aponta o uso da ordem $\mathrm{V}($ erbo)S(ujeito) como uma estratégia de descontinuidade discursiva, na medida em que esse tipo de estrutura geralmente apresenta como sujeito um elemento 'novo', não referido anteriormente no texto. A ordem SV, por outro lado, consistiria numa estratégia de continuidade discursiva por ser o sujeito um elemento partilhado no discurso e, portanto, não considerado como novo. Outros estudos de viés funcionalista (dentre os quais Votre \& Cezario, 1996; Spano, 2002) seguem a mesma direção dessa análise ao assumirem que a ordem VS se caracteriza por apresentar como sujeito um elemento portador de informação nova.

A motivação observada por esses autores referente à novidade do sujeito, de caráter essencialmente funcionalista, foi também atestada por Berlinck (1989) como sendo relevante em amostras do século XVIII. Com o intuito de descrever o PB em registro menos formal, mais próximo do vernáculo, a autora utilizou cartas pessoais como fonte de dados. 
A análise da posição do sujeito entre os séculos XVIII e XX revelou a progressiva diminuição na frequência de sujeito posposto ao verbo, bem como detectou a mudança dos principais fatores determinantes da ordenação ao longo do período analisado. Para cada corpus foi verificado um grupo distinto de fatores determinantes da ordem VS, sendo os principais deles, em cada século, o (i) status informacional do sujeito, o (ii) tipo de predicador e a (iii) transitividade verbal ${ }^{75}$, respectivamente.

O quadro interpretativo do fenômeno apresentado pela autora indicia o processo de reanálise sofrido pelos fatores ligados à variação da ordem, em decorrência do qual se efetuou a re-hierarquização desses condicionantes ao longo dos três séculos. O processo caracterizou-se por apresentar, num primeiro momento, princípios de natureza mais funcional, adquirindo, a partir do século XIX, orientação mais formal. Vale ressaltar que, nessa análise, a perspectiva mais funcional ou formal não é definida previamente, mas emerge do próprio corpus, que revela essa caracterização em sua diacronia.

Em decorrência desse processo, a produtividade de atualizações na ordenação VS que passou a sofrer restrições estruturais impostas pelo número de argumentos verbais (Berlinck, 1989; Kato, 2000), se reduzindo significativamente. Tais restrições são consequência do fato de que a posposição do sujeito é desfavorecida em construções pluriargumentais ${ }^{76}$, devido à possibilidade de interpretação equivocada dos argumentos.

\footnotetext{
75 Segundo a definição de Berlinck (1989: 112), os três fatores referem-se (i) ao "grau de novidade do sujeito", (ii) à "relação entre a forma como o predicador expressa a situação e o tipo de argumento externo que ele exige", e (iii) ao "número e tipo de argumentos que exige e o número e tipo de argumentos presentes na sentença".

${ }^{76}$ São consideradas construções pluriargumentais aquelas em que o verbo possui dois ou mais argumentos, cuja posição na sentença pode favorecer interpretações ambíguas, como no exemplo abaixo, em que não se tem uma leitura clara do agente e paciente envolvidos no ato de beijar:
}

(a) Beijou o menino a mãe.

Por essa razão, esses contextos tendem a atualizar, no PB atual, a ordem canônica SVO. 
Por outro lado, as construções monoargumentais, por evitarem a ambiguidade na interpretação de sentenças, favoreceriam a ordem VS.

Em uma perspectiva diacrônica, Berlinck aponta a correlação entre o aumento do uso da ordem SV, particularmente em construções transitivas, e a diminuição da produtividade do sistema pronominal acusativo ${ }^{77}$, constatação baseada na hipótese de Tarallo \& Kato $(2006)^{78}$ para os clíticos. Segundo os autores, a atualização de argumento em forma de clítico confere um caráter de monoargumentalidade ao verbo, que passa a constituir com o elemento cliticizado um único vocábulo fonológico.

Complementarmente à proposta de Berlinck, Torres Morais (1993) atesta a relação entre a ordem de constituintes e os clíticos, no que concerne à colocação desses elementos na sentença. $\mathrm{O}$ estudo, realizado a partir de peças teatrais produzidas entre os séculos XVIII e XX, enfoca as sentenças principais finitas no PB. Baseando-se na Teoria de Princípios e Parâmetros ${ }^{79}$, a autora parte do pressuposto que línguas que favorecem a ordem VS resultante de movimento do verbo para uma posição estrutural alta tendem a privilegiar a ênclise em contextos em que o verbo se atualiza no início da sentença principal, segundo postula a Lei Tobler-Mussafia, também conhecida como "lei da ênclise" (Torres Morais, 1993: 271). Essa hipótese correlaciona a ordem VS à ênclise, e a ordem SV a colocações proclíticas.

De fato, constatou-se, ao longo da história do $\mathrm{PB}$, a perda generalizada de construções verbo-sujeito associada a uma elevação no uso da próclise. O decréscimo na frequência da ordem VS é justificado, no estudo, pela reanálise estrutural da ordem de constituintes. A mudança, consolidada ao longo do tempo, seria consequência das

\footnotetext{
${ }^{77}$ Os dados sobre mudança no sistema pronominal são resultado das pesquisas de Omena (1978) e Duarte (1986).

${ }^{78}$ Trata-se da republicação do texto "Harmonia trans-sistêmica: variação intra- e inter- linguística", publicado originalmente em 1989.

${ }^{79}$ A autora baseou-se em Chomsky 1986, 1989.
} 
'falhas' de input ${ }^{80}$ na aquisição da gramática pelas gerações mais jovens, a qual se alterou gradativamente, resultando em mudança paramétrica, perspectiva que associa a teoria gerativa à variação e mudança histórica.

O processo de reanálise da ordem no PB teria a origem de sua explicação no português arcaico, em que são frequentes realizações com sujeito posposto. Nesse período o português é descrito como sendo uma língua V2 (Ribeiro, 1995), caracterizada por construções XVS, e na qual o movimento do verbo normalmente ocorre para uma posição alta, no interior do sintagma complementizador CP. Esse fato tem como consequência um movimento análogo do sujeito, que para configurar sentenças SVO move-se para spec, $\mathrm{CP}$, como representado na estrutura abaixo:

(I) Português Arcaico

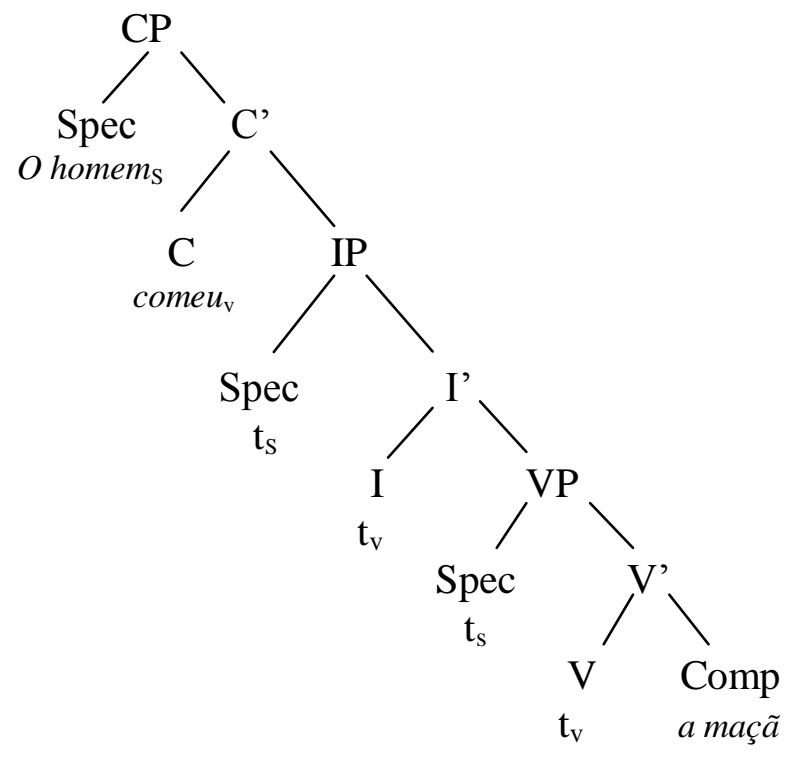

\footnotetext{
${ }^{80} \mathrm{~A}$ análise da autora pressupõe que a língua é um sistema de conhecimentos interiorizados na mente humana, sendo sua gramática determinada a partir dos dados linguísticos que constituem o input de um indivíduo ou geração, de modo que os dados produzidos por uma geração anterior são interpretados pela geração seguinte e utilizados na parametrização da faculdade da linguagem.

O input recebido por uma geração pode ser insuficiente para demonstrar todos os parâmetros a ele relacionados, ou para que estes sejam deduzidos pela geração mais nova, o que resultaria em 'falhas' de interpretação. No entanto, estas 'falhas' devem ser percebidas não como um problema, mas como uma característica intrinsecamente relacionada às dinâmicas de aquisição e mudança linguísticas, não constituindo prejuízo para a língua, mas a enriquecendo.
} 
No entanto, o aumento da frequência de construções SVX ocorrido a partir do século XVIII parece ter acarretado a realização, por parte das gerações mais jovens, de uma leitura estrutural diferenciada em relação às línguas V2 e desencadeado uma mudança de gramática (L-I). As construções com sujeito anteposto não seriam mais licenciadas da mesma forma, pois "na reanálise as declarativas SVX poderiam estar sendo analisadas sem movimento do V para uma posição mais alta" (Torres Morais, 1993: 287), ou seja, sem acionar o nódulo CP, como em (II) abaixo:

(II) Português Moderno

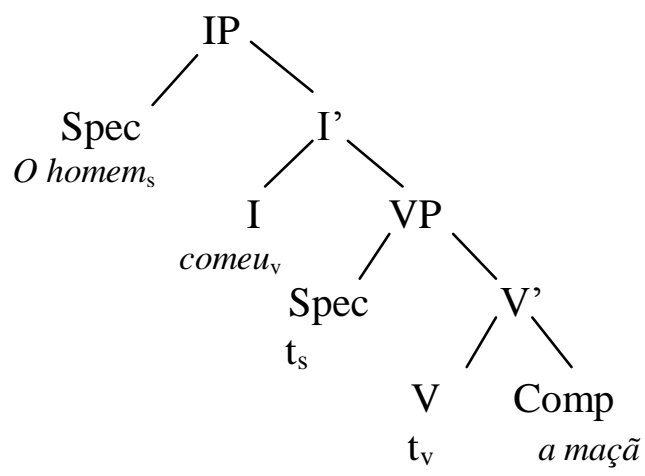

Nesse contexto de variação, a estrutura de frase desenvolvida teria gerado novos padrões de colocação dos clíticos, manifestando-se através de uma maior incidência de próclise ao longo do período analisado ${ }^{81}$.

Com base nos estudos acima expostos pode-se afirmar que, a partir do século XIX, a ordem VS passou a se definir principalmente por fatores estruturais, cuja atuação se intensificou progressivamente. Desta observação resulta que essa ordem, no PB atual, ocorre preferencialmente em contextos específicos de atualização, sendo eles,

\footnotetext{
${ }^{81}$ Estudos sobre ordem em diversas línguas apontam ainda a correlação entre a inversão Sujeito-Verbo e a ocorrência de sujeito nulo. Essas duas propriedades - entre outras - integrariam o parâmetro pro-drop, de modo que uma língua em que esse parâmetro fosse marcado positivamente seria uma língua de sujeito nulo e que permite posposição do sujeito ao verbo. Essa correlação é importante, contudo, não pertinente para nosso trabalho, cujo foco está voltado para a posição do sujeito realizado.
} 
principalmente, construções monoargumentais, em particular com verbos inacusativos (Kato, 2000), construções passivas (Pontes, 1987) e com verbos copulares e pronominais com se (Kato et alii, 1996) ${ }^{82}$ :

(1) Quando chegou o balé russo aqui em São Paulo.

(2) ... fizeram com que fosse perdida a guerra.

(3) ... eram quinze cruzeiros uma fruta-do-conde.

(4) ... se impôs essa atitude sua.

As análises da ordem de constituintes por diferentes autores, ainda que partam de diferentes perspectivas, convergem em seus resultados, correlacionando às diferentes ordenações os mesmos contextos de atualização ou fatores condicionantes, divergindo no que concerne aos princípios básicos de análise.

\subsubsection{Juízos tético e categórico: a colocação do sujeito}

A colocação do sujeito define-se também em virtude da atuação de fatores de natureza menos estrutural, como a definitude/não-definitude desse constituinte, aspecto semântico baseado na relação entre o referente discursivo associado ao sujeito e referentes discursivos previamente apresentados no texto, constituindo-se, entre eles, uma relação de identidade (Britto, 1998: 2933). Haveria uma correlação entre a definitude do SN sujeito e sua colocação, sendo o traço [-definido] característica de

\footnotetext{
${ }^{82}$ Apud Berlinck, Augusto \& Scher, 2001: 224.

${ }^{83}$ Conceito baseado em Enç (1991).
} 
sujeitos pós-verbais no PB, observação reiterada em diferentes estudos (Nascimento, 1984 apud Britto, 1998; Spano, 2002; Votre \& Cezario, 1996; e outros).

(5) Viajou um estranho comigo.

(6) Telefonou um cliente. ${ }^{84}$

A relação entre definitude do sujeito e ordem aplica-se também às formas de atualização dos juízos lógicos tético e categórico. Essas noções distinguem-se por terem como objeto uma descrição e uma predicação, respectivamente (Britto, 1998:11), e têm sido analisadas em estudos linguísticos que tomam como pressuposto a hipótese de que a diferentes juízos corresponderiam expressões sintáticas distintas.

A realização desse princípio no japonês é atestada e descrita por Kuroda (1972, $1976)^{85}$. O autor verifica que, nessa língua, o juízo tético se expressa por meio do SN "ga", e o categórico, do SN "wa". A partir da comparação entre japonês e inglês, defende que as sentenças (7-9) ${ }^{86}$ expressam juízo tético, por apresentarem um evento sem, no entanto, enfatizar seus participantes.

(7) A dog is running.

(8) There is a dog running.

(9) Inu ga hasitte iru.

\footnotetext{
${ }^{84}$ Tarallo \& Kato, 2006: 33.

85 Conforme descrito em Britto, 1998. The Categorical and The Thetic Judgement. Foundations of Language 9:153-185, 1972; Subject. Syntax and Semantics: 1-16, 1976.

${ }^{86}$ A sentença em (8) recebe interpretação tética desde que tomada como paráfrase de (7).
} 
Esses contextos se caracterizam por apresentar como sujeito elementos [definidos]. Diferentemente, sujeitos [+definidos] correspondem à atualização de juízo categórico, cuja leitura é licenciada, em japonês, pelo emprego do SN "wa":

(10) Neko wa asoko de nemutte iru

O gato lá dormindo está

No contexto de (10) codifica-se sintaticamente um juízo categórico, dado que a presença do item "wa" indica tratar-se de um gato em particular, que na sentença é primeiramente destacado para então receber uma predicação.

As correlações atestadas entre os juízos e suas formas de expressão têm como decorrência que as partículas "wa" e "ga", responsáveis por atribuir a uma sentença valor categórico ou tético, podem ser interpretadas, conforme a designação de Kuroda $(1992)^{87}$, como marca de tópico e marca de nominativo. Desta interpretação resulta que o juízo tético apresenta um 'sujeito propriamente dito', e o categórico tem sujeito com função de tópico, como ocorre em (11) e (12), respectivamente:

(11) Chegaram as cartas.

(12) As cartas chegaram.

A partir dos exemplos acima, extraídos da análise de Kato $(1988)^{88}$ para o PB, é possível entrever que, nessa língua, a codificação de juízos está relacionada à ordem de constituintes. A autora atestou haver correspondência entre as ordens SV e VS e os juízos categórico e tético, respectivamente, em construções com verbos inacusativos.

\footnotetext{
${ }^{87}$ Apud Britto, 1998: 20.

${ }^{88}$ Ibidem.
} 
Com relação aos inergativos e transitivos, Britto (1998), com base em Kuroda, propõe para o juízo tético a atualização na forma SV, e para o categórico, em estrutura com deslocamento à esquerda e resumptivo-sujeito ${ }^{89}$ :

(13) Joana ligou.

(14) A Joana ela $_{\text {igou }}$ lig. $^{9}$.

Segundo a autora, a sentença (13) seria adequada se dita a uma pessoa ao chegar em casa, sem que essa pessoa tenha perguntado nada. Não expressaria, portanto, expectativa alguma em relação à pessoa que ligou. Já em (14) o referente "a Joana" é pressuposto ou esperado no discurso, sendo a sentença apropriada a um contexto em que se espera o telefonema de Joana. O sujeito recebe então certa proeminência, que lhe é atribuída pelo deslocamento ${ }^{91}$ do SN (Joana) e reatualização em forma pronominal $(\text { ela })^{92}$. Seguindo a postulação de Kuroda para o japonês, podemos interpretar os sujeitos de (13) e (14) como sendo, respectivamente, sujeito stricto sensu ${ }^{93}$ e com função de tópico, caracterização resultante da atribuição de casos nominativo e tópico.

Como se pode ver, a forma de codificação de juízos com verbos transitivos verificada no PB atual é definida formalmente. Para isso, a língua recorre a elemento altamente produtivo, o sujeito pleno pronominal, que se atualiza como resumptivosujeito, refletindo a tendência do $\mathrm{PB}$ atual de preenchimento formal do sujeito ${ }^{94}$. Embora não trate do mesmo período, Berlinck (1989) aponta na mesma direção no que concerne ao aspecto formal do condicionamento da ordem, correlacionando sua

\footnotetext{
${ }^{89}$ As sentenças (13) e (14) apresentadas por Britto foram adaptadas de exemplos de Martins (1994) para o Português Europeu.

${ }^{90}$ Britto, 1998: 28.

${ }^{91}$ Entende-se por deslocamento a colocação do constituinte, retomado por pronome, na periferia da sentença.

92 Essa reatualização tem sido chamada pela literatura de "pronome resumptivo".

${ }^{93}$ Segundo a terminologia adotada por Britto (1998).

${ }^{94}$ Estudos sobre a realização do sujeito têm apontado a crescente produtividade desse item em sua forma pronominal no PB (Duarte 1993, 1995, e outros).
} 
definição à estrutura argumental do verbo, e apontando a importância, na variação, da cliticização do argumento interno de verbos transitivos.

\subsection{Conexão de linhas}

Retomando os resultados diacrônicos de Berlinck (1989) e os de outros estudos, observa-se que, até o século XVIII, a ordem no PB definia-se funcionalmente em um contexto relativamente livre do ponto de vista estrutural. Porém, com o decorrer dos séculos, esses contextos passaram a ser mais restritos estruturalmente, restringindo também, por consequência, a amplitude de atuação dos fatores funcionais - que, no entanto, continuam operantes. Esses fatos foram identificados por estudiosos de diferentes linhas.

Nesse contexto, vale notar que diferentes perspectivas teóricas sobre um mesmo objeto de estudo podem trazer leituras equivalentes, conflitantes, ou ainda complementares. Essa verificação traz à tona a importância, para os estudos linguísticos, de se abrandar a oposição entre racionalismo e empirismo, proposta por Tarallo \& Kato (2006), referindo-se às linhas teóricas gerativa e da sociolinguística variacionista, proposta que endossamos aqui e que acreditamos poder ser estendida também ao funcionalismo, cognitivismo e outras vertentes de análise. A consideração das contribuições de diferentes teorias só vem a favorecer a pesquisa linguística, ampliando as possibilidades de compreensão do objeto de estudo (Berlinck, Augusto \& Scher, 2001).

Assim como as linhas gerativa e sociolinguística enfocam o indivíduo e o social, respectivamente, a proposta de Bourdieu para a sociologia e para o uso da língua 
envolve esses dois elementos. Do mesmo modo que a variação linguística individual é determinada, entre outros, por condicionantes sociais, um indivíduo expressa, por meio do habitus, marcas que o identificam e definem na sociedade da qual faz parte.

Por outro lado, essas marcas, exteriores, são resultantes da exposição a práticas sociais, uma espécie de input comportamental, que identifica o indivíduo em seu grupo de origem. Tendo em vista essa analogia, parece-nos possível, além da conjunção de teorias linguísticas, acrescentar um olhar histórico e/ou sociológico sobre o material de pesquisa, o que permitirá um aprofundamento ainda maior na interpretação das produções. 


\section{Capítulo 3}

\section{A Posição do Sujeito Sentencial: ramificação dos trilhos}

\subsection{A linha da ENC}

Os trabalhos sobre ordem de constituintes apresentados no Capítulo 2 foram baseados em corpora de natureza informal, devido ao intuito de seus autores de buscar uma descrição e análise do vernáculo. Nesse aspecto, o presente estudo diferencia-se dos anteriores justamente por tomar como fonte de dados textos formais, produzidos por sujeitos que, em sua época, não somente eram considerados cultos, mas eram sobretudo difusores de cultura. Não é, portanto, muito surpreendente a verificação de uma frequência de ordem $\mathrm{VS}^{95}$ maior do que a atestada para o mesmo período em outras pesquisas, dado que o registro formal e, particularmente, em sua forma tida como culta, tende a se caracterizar por formas linguísticas mais conservadoras. As porcentagens da tabela a seguir, referente aos dados coletados nas cartas e atas da ENC, apontam essa tendência.

Tabela 1: Frequência geral de sujeitos posposto e anteposto

\begin{tabular}{|l|c|c|}
\hline & $\mathbf{n}^{\mathbf{o}}$ oc. & \% \\
\hline Sujeito Anteposto & 159 & $51,96 \%$ \\
\hline Sujeito Posposto & 147 & $48,04 \%$ \\
\hline Total & 306 & $100 \%$ \\
\hline
\end{tabular}

Verificamos que o índice de sujeito posposto encontrado no corpus desta pesquisa é bastante elevado em comparação aos resultados obtidos por outros estudos para o vernáculo ou registro escrito informal. Berlinck (1989: 97) atesta o índice de

\footnotetext{
${ }^{95}$ Adotamos neste capítulo a nomenclatura VS tanto para construções VS como XVS ou VXS, tomando-a como designação genérica para posposição do sujeito ao verbo.
} 
$31 \%$ de ocorrências VS nos dados do século XIX, levantados de cartas pessoais do ano de 1850. No mesmo período, Torres Morais (1993: 284) verifica média de 16\% de VS em peças de teatro, datadas de 1845 e 1882.

A diferença percentual de VS entre os textos teatrais (Torres Morais, 1993) e as cartas (Berlinck, 1989) pode indicar o peso do gênero textual na realização dos constituintes sentenciais. Contudo, observamos que à primeira peça teatral corresponde um índice de $24 \%$ de sujeito posposto, frequência que cai para $9 \%$ no segundo texto. A discrepância dos valores obtidos nas duas obras teatrais, com índice maior de VS no texto de 1845 , encontra respaldo na tendência normativa do autor, segundo propõe Torres Morais (1993:288). Diante desse quadro de resultados, vale ressaltar que tanto esta autora como Berlinck definem o século XIX como período de ebulição no que se refere às mudanças relacionadas à ordem de constituintes, o que pode ter se refletido nas diferenças de ordenação observadas nas duas peças. Ademais, o momento de produção dos textos pode ser significativo para justificar a diferença de frequência VS. Entendemos que, além de o espaço de quarenta anos entre a produção das obras ser um período de tempo considerável, remete a um período emblemático da história do Brasil, em que as produções tornam-se mais suscetíveis a interferências de natureza extralinguística, que foram intensas no período em questão.

Verificamos, pelos índices apresentados na Tabela 1, que o quadro geral de ocorrências SV e VS é bastante aproximado. A distinção das ocorrências de cartas e atas apresentada na Tabela 2 revela não ser pertinente, de modo geral, o tratamento diferenciado dos dois tipos de texto: 
Tabela 2: Distribuição da Posição do Sujeito por tipo de texto ${ }^{96}$

\begin{tabular}{|c|c|c|c|c|}
\hline & \multicolumn{2}{|c|}{ Cartas } & \multicolumn{2}{c|}{ Atas } \\
\hline Sujeito Anteposto & 77 & $51,68 \%$ & 82 & $52,23 \%$ \\
\hline Sujeito Posposto & 72 & $48,32 \%$ & 75 & $47,77 \%$ \\
\hline Total & 149 & $100 \%$ & 157 & $100 \%$ \\
\hline
\end{tabular}

Além da proximidade do índice percentual, o viés formal das produções estudadas motivou o tratamento conjunto dos dados. A despeito de tais semelhanças, observadas ao se tomar os resultados sem maiores distinções qualitativas, os textos aqui analisados apresentam certas particularidades, as quais serão ressaltadas quando se mostrarem pertinentes.

Com efeito, os números levantados a partir de nosso corpus apontam uma considerável produtividade da ordem VS no período em estudo, mas não esclarecem qualitativamente o que ocorre nas estruturas analisadas. Para obter um detalhamento dessas ocorrências nos voltamos para os dados e, a partir deles, buscamos verificar por que ocorre uma ou outra ordem, delineando assim uma interpretação do quadro linguístico encontrado.

\subsection{Possíveis fatores condicionantes}

A Sociolinguística tem como pressuposto que a variação e mudança em uma língua não são aleatórias, mas motivadas por elementos internos a essa língua (de natureza fonética, sintática, etc.) ou externos a ela, relativos ao falante (como grau de

\footnotetext{
${ }^{96} \mathrm{O}$ corpus desta pesquisa foi constituído a partir de dois tipos de texto, cartas e atas. Como não observamos pertinência das idiossincrasias genéricas em relação ao fenômeno analisado, optamos por não adentrar na questão do gênero textual, pouco relevante para o presente estudo, no qual buscamos uma descrição da língua em seu registro formal, característica apresentada tanto pelas Cartas quanto pelas Atas. Em momentos em que se mostrarem pertinentes, as distinções entre os textos serão ressaltadas, como se poderá observar ao longo da análise.
} 
escolaridade, faixa etária, etc.) ou à situação de produção. Ainda que não consideremos o objeto de análise deste estudo como uma variável no sentido estrito laboviano, entendemos que a perspectiva variacionista pode contribuir para sua descrição e interpretação, posto que, como revelam outros estudos, a posição do sujeito na sentença é definida por condicionamentos linguísticos diversos, como mostra detalhadamente Berlinck (1989), e extralinguísticos. Para dar conta da interpretação dos dados, realizamos uma análise não apenas quantitativa, mas também qualitativa.

Com o intuito de verificar os possíveis condicionamentos ligados às realizações de sujeito anteposto e posposto no corpus analisado, elencamos fatores cuja presença poderia interferir no sentido de favorecer a ocorrência de uma ou outra das ordens analisadas. Alguns desses fatores foram selecionados de estudos anteriores sobre o português do século XIX ou atual, outros foram estabelecidos a partir da observação e reflexão sobre os dados desta pesquisa. Tais fatores serão tratados nas próximas subseções.

\subsubsection{Tipo verbal}

Os estudos acerca da ordem de constituintes comumente elegem a estrutura argumental do verbo como um importante condicionante de variação, tendo sido atestada sua pertinência em corpora variados. Conforme abordamos no Capítulo 2, o fator mostra-se atuante tanto no português sincrônico (Pontes, 1987; Tarallo \& Kato, 2006) como no diacrônico (Berlinck, 1989).

Com o objetivo de verificar a pertinência desse fator nos registros da Escola Normal, quantificamos os dados relativamente ao tipo de verbo atualizado. No entanto, 
os números podem também nos desviar de uma análise mais acertada, na medida em que algumas das construções são formulares ou expressões que tendem a ser atualizadas em um tipo específico de ordem. Com o intuito de evitar uma leitura tendenciosa das amostras, levantamos os principais desses contextos e excluímos da totalidade dos dados os mais formulares e restritos a determinadas sequências de constituintes. Desse grupo destacamos alguns, como a sentença final de cada ata, parte da fórmula utilizada no encerramento desse tipo de texto, como segue:

(1) Nada mais havendo á tractar-se foi encerrada a sessão e, para constar, lavrada a presente acta.

$\mathrm{Eu}$, JBenevides, secretario, a escrevi e assigno. (A, 11/3/1895)

Foi também desconsiderada a expressão “Acompanha(m) o presente...", encontrada em 22 das 124 cartas emitidas pela ENC. A expressão é correspondente, em termos pragmáticos, à fórmula "Segue anexo..." utilizada atualmente na comunicação via email. O dado a seguir ilustra esse tipo de ocorrência:

(2) Acompanham o presente contas de despesas effectuadas na Escola Modelo, annexa á esta, na importancia deRs [141\$000] cujo pagamento peço-vos que ordeneis seja feito ao respectivo porteiro Antonio Francisco Barbosa. (C, $8 / 8 / 1894)$

O corpus apresenta, além dos contextos acima referidos, sintaticamente rígidos, i.e., formulaicos, certos verbos que parecem favorecer a realização de uma ordem determinada. No entanto, a despeito dessa tendência, nenhum deles foi empregado 
exclusivamente com sujeito anteposto ou posposto. Quando atestada variação considerável, optamos por mantê-los no corpus. Esses dados, incluindo os não contabilizados, serão importantes para a análise, auxiliando-nos a esclarecer a relevância dos fatores na determinação das ordens atualizadas, conforme mostraremos posteriormente.

Dentre os verbos acima referidos, destacamos inicialmente o grupo dos dicendi $i^{97}$, cuja ocorrência foi fortemente atestada nas Atas. Esses textos, por consistirem em relatos das reuniões de professores e direção da Escola, não só propiciam como requerem o emprego de verbos dessa natureza, indicando os sujeitos que se manifestavam nas reuniões. Observamos dois modos de realização dos dicendi: com argumento interno atualizado, normalmente em forma de oração:

(3) Disse o Snr. Director, finda a leitura da referida noticia, que não podia impunemente consentir que os esforços de todo o pessoal d'esta Escola, em dous annos de quotidiano e dedicado trabalho, para dar á Escola o prestigio de que está gozando não só n'este Estado como em todos os outros, fôsse annullado por um dos proprios lentes da Escola e por isso tinha com profundo pezar de usar de uma de suas attribuições $(\mathrm{A}, 12 / 12 / 1895)$

e compondo oração parentética, estrutura na qual o uso de ordem VS é categórico:

(4) Trata-se, disse elle, de um alumno inapplicado que desde o começo do anno lectivo se mostrou pouco assiduo ás suas aulas, desculpando-se sempre com doenças. (A, 16/11/1895)

\footnotetext{
${ }^{97}$ Verbos que expressam uma elocução em discurso direto ou indireto, tais como dizer, declarar, falar, informar, sugerir, entre outros. No material analisado, essas formas ocorrem exclusivamente com discurso indireto.
} 
Em outros contextos, os verbos dicendi tendem a preceder o sujeito, mas não ocorrem exclusivamente com essa ordem. Verificamos uma maior frequência dessa forma de atualização com 'dizer', havendo $80 \%$ de ocorrências com sujeito posposto. Por sua vez, 'declarar' apresenta uma maior variação, sendo os dados com sujeito posposto correspondentes a $66 \%$ do total de ocorrências com esse verbo. Essas observações fazem-nos entrever que verbos dicendi favorecem a ordem VS, mas nem todos os verbos dessa classe se comportam da mesma maneira.

A expressão 'pediu a palavra' pode ser analisada de modo semelhante. As quinze ocorrências VS correspondem a quase $94 \%$ das sentenças em que se atualiza, em oposição a apenas uma com sujeito anteposto. Devido a seu caráter formular e à baixa variação atestada, a construção foi excluída da quantificação, porém mantida na análise qualitativa dos dados.

Nas cartas encontramos as expressões 'apresentou-se e reassumio o exercicio o lente...', e 'reassumio o exercício do cargo de...', empregadas exclusivamente com sujeito posposto. No entanto, devido ao fato de haver poucos dados desse tipo (apenas cinco), não podemos afirmar com segurança a associação da referida estrutura à posposição do sujeito, ainda que o contexto e os dados, como o do exemplo que segue, pareçam favorecer tal hipótese.

(5) Levo ao vosso conhecimento para o devido effeito, que, n'esta data $\underline{\text { reassumio }}$ o exercicio do cargo de directora da Escola Modelo Miss Marcia P.Browne. (C, 12/6/1894)

Separando então as porcentagens por tipo de verbo, temos o que segue: 
Tabela 3: Tipo de Verbo X Posição do sujeito

\begin{tabular}{|l|c|c|c|c|}
\hline & \multicolumn{2}{|c|}{$\begin{array}{c}\text { S. Anteposto } \\
\text { \% }\end{array}$} & \multicolumn{2}{c|}{$\begin{array}{c}\text { S. Posposto } \\
\text { n. oc. }\end{array}$} \\
\% & n. oc. \\
\hline Copulares & 68,29 & $28 / 41$ & 31,71 & $13 / 41$ \\
\hline Biargumentais & 53,90 & $83 / 154$ & 46,10 & $71 / 154$ \\
\hline Monoargumentais & 30,30 & $10 / 33$ & 69,70 & $23 / 33$ \\
\hline Passivas Sintéticas & 30,00 & $9 / 30$ & 70,00 & $21 / 30$ \\
\hline Passivas Analíticas & 60,42 & $29 / 48$ & 39,58 & $19 / 48$ \\
\hline
\end{tabular}

\subsubsection{Os verbos copulares}

Conforme se pode observar na Tabela 3, os verbos copulares atualizam-se preferencialmente em ordem SV (68,29\%), mas a frequência VS mostra-se também significativa. O resultado aproxima-se ao do estudo de Berlinck (1989: 100), em que foram atestados $30 \%$ de ordem VS para essa classe verbal nos dados do século XIX (1850). No corpus da presente pesquisa, esses verbos ocorrem com maior frequência nas atas, preferencialmente com o verbo ser (6-7):

(6) Em relaçaõ ás licenças aos professores da Escola saõ applicaveis as disposições estabelecidas para os professores primarios, nos termos do art. 527 do citado Reg. da Instr. Publica. (C, 7/3/1894)

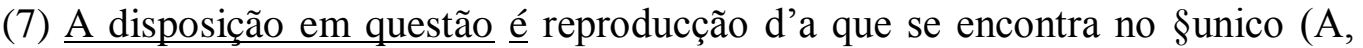
2/4/1895)

Essas estruturas realizam-se no corpus quase exclusivamente com função predicativa (8), apresentando um atributo referente ao sujeito sintático. As ocorrências 
com função equativa ${ }^{98}$ não foram contabilizadas por não permitirem a distinção precisa entre sujeito e predicativo, como exemplificado em (9):

(8) A fim de organisar convenientemente o gabinete de chimica d'esta Escola torna-se indispensavel a acquisição de vasilhame adaptavel ás estantes feitas - á saber: (C, 20/9/1894)

(9) a interpretação dada ao disposto no $\S$ unico do art. $5^{\circ}$. do Regimento Interno é a verdadeira (A, 2/4/1895)

Nas sentenças do corpus o sujeito ocorre antes ou depois da sequência CópulaPredicativo, estrutura fixa nas ocorrências, não sendo identificados outros tipos de disposição dos constituintes nesse contexto verbal.

\subsubsection{As construções passivas}

Considerando as ocorrências do corpus em números absolutos, nota-se que a ocorrência de passiva analítica é significativamente maior que a passiva sintética. Contudo, esta construção apresenta o maior índice de posposição do sujeito, conforme se pode observar abaixo, na reprodução parcial da Tabela 3 apresentada no início desta seção.

\footnotetext{
${ }^{98}$ Registramos apenas três casos de construção equativa.
} 
Tabela 3 (parcial): Tipo de Verbo X Posição do sujeito

\begin{tabular}{|l|c|c|c|c|}
\hline & \multicolumn{2}{|c|}{$\begin{array}{c}\text { S. Anteposto } \\
\text { \% }\end{array}$} & \multicolumn{2}{c|}{$\begin{array}{c}\text { S. Posposto } \\
\text { n. oc. }\end{array}$} \\
\hline \% & n. oc. \\
\hline Passivas Sintéticas & 30,00 & $9 / 30$ & 70,00 & $21 / 30$ \\
\hline Passivas Analíticas & 60,42 & $29 / 48$ & 39,58 & $19 / 48$ \\
\hline
\end{tabular}

Ao se analisar a ordem de constituintes em construções passivas deve-se considerar que se trata de um contexto inacusativo, no qual o sujeito gramatical é o argumento interno do verbo. Por este motivo, apresentam maior tendência à realização de ordem VS, exemplificada nos dados (10) e (11) a seguir:

(10) Entretanto sempre foram justificados seus pontos e mesmo um, que correspondia á comparecimento tardio, foi retirado, evitando-se assim que o alumno perdesse o anno. (A, 16/11/1895)

(11) Posto em discussão o assumpto, estabeleceu-se longo debate (A, 2/12/1895)

Há casos, porém, em que o argumento interno se desloca de sua posição interna ao VP configurando a ordem SV.

(12) A prova oral (arguiçã̃) realizar-se-á a um ou mais dias uteis seguintes ao da prova escripta, conforme o numero de concurrentes inscriptos (C, 31/3/1894)

(13) Procedeu-se, então, ao julgamento dos exames dos alumnos do $2^{\circ}$ anno cujo resultado foi registrado no livro para esse fim destinado. (A, 10/12/1895) 
O fato de o sujeito gramatical nas passivas não coincidir com o argumento externo, mas com o interno, tem reflexos na concordância desse constituinte com o verbo. Mesmo textos produzidos com alto rigor normativo podem apresentar desvios à norma $^{99}$, justamente por haver um desajuste entre as estruturas realizadas na escrita/fala e suas propriedades linguísticas. O exemplo abaixo ilustra essa situação.

(14) Tenho a honra de levar ao vosso conhecimento, para o devido effeito, que, nesta data e nos termos do artigo $36 \mathrm{n}^{\circ} .4$ do Regimento Interno d'esta Escola, foi concedido quinze dias de licença com ordenado a professora adjuncta da Escola Modelo. D. [Garibaldeira] P. Machado. (C, 14/9/1894)

Em (14) a forma verbal singular não concorda com o SN plural "quinze dias de licença". Posto que a concordância se dá entre o verbo e seu argumento externo, o desvio identificado reitera o fato de o sujeito gramatical dessas construções, tanto sintéticas como analíticas, não ser de fato o argumento externo do verbo, e sim o argumento interno. Contudo tal desvio, longe de consistir em erro, é na verdade reflexo das propriedades linguísticas das construções passivas.

\subsubsection{Comportamento dos verbos mono e biargumentais}

A literatura sobre o fenômeno da ordem tem mostrado a relação entre a monoargumentalidade verbal e a posposição do sujeito. De acordo com essa tendência,

\footnotetext{
${ }^{99}$ Aqui, nos referimos às noções de norma e desvio sem assumi-las como parâmetro em nossa análise. Contudo, consideramos significativo que, mesmo em produções de caráter culto como as do corpus deste estudo, sejam identificados desvios que, de um ponto de vista não normativista, indiciam particularidades da língua.
} 
as amostras com verbos monoargumentais ${ }^{100}$ favoreceram a posposição do sujeito, numa frequência representativa em comparação aos resultados obtidos para os outros tipos verbais analisados, apresentando cerca de $70 \%$ de sujeito posposto. Realizaram-se, porém, as duas ordens possíveis tanto em contextos inergativos (15-16) como inacusativos (17-18).

(15) $[\ldots]$ - declarando-se inteiramente solidario com as reprovações havidas porque a meza examinadora procedeu correctamente, fazendo justiça, e sendo até benevolente. (A, 12/12/1895)

(16) De facto exercem o primeiro desde a referida dacta o cargo de porteiro deixando de prestar serviços como servente, e servio o segundo tambem desde então. (C, 12/9/1894)

(17) $[\ldots]$ que o exercicio das escolas publicas cessa abertamente nos dias que decorrerem de $1^{\circ}$ á 8 de Junho, no art.379 (C, 31/5/1894)

$$
\text { [...] figura apenas um porteiro na relação do pessoal. (C, 14/8/1894) }
$$

Contrariando a expectativa para os verbos biargumentais ${ }^{101}$, que supostamente deveriam privilegiar a anteposição do sujeito, foi encontrada uma elevada incidência de posposição. Para esclarecer esse quadro, nos voltamos para o corpus com o intuito de

100 Para a classificação das ocorrências, pretendíamos inicialmente separar verbos inergativos e inacusativos devido ao comportamento diferenciado que apresentam com relação à posição de atualização do sujeito. Esta preocupação deveu-se principalmente ao fato de que contextos inacusativos são apontados como favoráveis a realizações VS, inclusive no PB atual (Tarallo \& Kato, 2006). No entanto, devido ao baixo número de ocorrências desses verbos, optamos por agrupá-los aos inergativos numa categoria única, a dos "monoargumentais".

101 Consideramos como "biargumentais" verbos que apresentam simultaneamente argumento externo e interno. Incluímos nesse grupo duas ocorrências de verbo com argumento externo e dois argumentos internos (verbos bitransitivos, segundo a Gramática Tradicional). Devido ao baixo número de dados desse tipo, achamos desnecessário abrir uma categoria à parte para abrigá-los. Nessas ocorrências, o sujeito realiza-se antes do verbo. 
esmiuçar esse conjunto específico de dados. Buscamos verificar se essa frequência alta se deve à pouca pertinência do número de argumentos verbais como fator condicionante da variação no material analisado, ou se apresenta outras motivações.

Assim, separamos e quantificamos as ocorrências com verbos biargumentais distinguindo aquelas em que os dois argumentos, externo e interno, eram atualizados em forma de sintagma nominal ou preposicional, das ocorrências em que o argumento interno se realiza como clítico, pronome relativo ou oração, o que descaracteriza, ao menos sintaticamente, o aspecto biargumental dessas construções. Esta distinção foi orientada pela hipótese de que esses últimos elementos, devido a sua natureza sintática diferenciada, e por não poderem ser confundidos com o sujeito, favorecem a posposição deste constituinte (Tarallo \& Kato, 2006 [1989]).

Da quantificação realizada, resultou que a atualização de dois argumentos SN correlaciona-se mais fortemente ao sujeito anteposto (19), mas não exclusivamente, como se verifica em (20) e (21):

(19) A commissão examinou os textos legaes e regulamentares existentes sobre o assumpto, (A, 3/9/1895)

(20) Em officio de $n^{\circ} 55$ de 2 de Julho de 1894 enviou esta Directoria contas da despezas effectuadas na Escola-Modelo na importancia de Rs:210.100 (C, 17/7/1894)

(21) Absolutamente não contem o parecer a menor referencia pessoal ao autor da proposta sob o ponto de vista de ser-lhe feita qualquer censura. (A, $19 / 11 / 1895)$ 
Observe-se, no entanto, que as ocorrências de transitivo com sujeito na forma de SN posposto (20-21) são iniciadas por elemento adverbial, configurando a estrutura XVS, típica do português clássico.

A Tabela 4 apresenta as diferentes formas de realização do argumento interno em contextos transitivos:

Tabela 4: Forma do argumento interno de verbos transitivos

\begin{tabular}{|c|c|c|c|c|}
\hline & \multicolumn{2}{|c|}{ S. Anteposto } & \multicolumn{2}{|c|}{ S. Posposto } \\
\hline & $\%$ & n. oc. & $\%$ & n. oc. \\
\hline Sintagma Nominal & 65,06 & 54 & 36,62 & 26 \\
\hline Sintagma Preposicionado & 9,64 & 8 & 11,27 & 8 \\
\hline Pronome relativo/Oração & 22,89 & 19 & 50,70 & 36 \\
\hline Clítico & 2,41 & 2 & 1,41 & 1 \\
\hline Total & 100,00 & 83 & 100,00 & 71 \\
\hline
\end{tabular}

Atestamos que $65,06 \%$ dos dados com sujeito anteposto apresentaram argumento interno atualizado como $\mathrm{SN}$, sendo aproximadamente $35 \%$ realizados sob outras formas, com destaque para contextos com pronomes relativo ou orações (22) e sintagmas preposicionados (23) - estes, como argumento de verbos transitivos indiretos.

(22) (...) á fim de que a Congregação resolvêsse se deveria ser ou não deferido. $(\mathrm{A}, 10 / 12 / 1895)$

(23) Sua duvida consistia em dever ou não ser extensiva aos alumnos do $4^{\circ}$ anno a disposição do referido $\S 1^{\circ}$ do art. 122 (...) (A, 2/12/1895)

Com relação ao argumento interno das estruturas com sujeito posposto, o quadro é o inverso do obtido para a ordem direta. Enquanto nesta ordem $65 \%$ das amostras se 
caracterizam pela presença de um SN como argumento interno, os contextos com sujeito pós-verbal apresentam cerca de $36 \%$. Tal resultado indica, mais do que o peso da estrutura argumental do verbo, a relevância da forma de realização de seus argumentos como possível fator determinante da ordem de constituintes atualizada. Nesse sentido, confirma-se a hipótese de que a realização de dois (ou mais) argumentos verbais desfavorece a posposição do sujeito, reiterada também pelo fato de 50,70\% dos dados apresentarem argumento interno na forma de pronome relativo ou oração.

No corpus desta pesquisa, a posposição do sujeito parece estar dissociada da questão dos clíticos, relação apontada por Torres Morais (1993), ao associar a ordem VS ao uso da ênclise; e Tarallo \& Kato (2006 [1989]), com a hipótese da monoargumentalidade ${ }^{102}$. As correlações propostas por esses autores, apesar de pertinentes, não são observáveis no corpus devido à baixa produtividade de clíticos nas amostras.

Ao considerar separadamente as ocorrências dos dois gêneros textuais, uma interessante distinção se faz notar. Destaca-se, nas Atas, o índice de 47,37\% de argumentos oracionais, justificado pela presença de verbos dicendi e sua estrutura argumental. Nas construções com sujeito posposto, o percentual sobe para 54,29\%.

Entre os transitivos encontram-se também construções com verbos leves ${ }^{103}$, compostas por verbo pouco preciso semanticamente acompanhado de substantivo que designa um evento (cf. Scher, 2003), exemplificadas em "tomar uma deliberação", "fazer donativo", etc. Essas estruturas em geral têm equivalência em formas verbais de maior especificidade semântica, como “deliberar”, “doar”.

\footnotetext{
${ }^{102}$ Tais propostas são apresentadas no Capítulo 2 deste estudo.

${ }^{103}$ Alguns autores analisam essas construções como intransitivas por entenderem que o substantivo que acompanha o verbo, geralmente um deverbal, não pode ser interpretado como objeto (Poustma, 1926 apud Scher, 2003). Optamos por classificar os dados de construções com verbos leves constantes no corpus como transitivos, com base no fato de que a unidade semântica entre verbo e substantivo, ao menos no período em que foram produzidos os textos analisados, podia ser sintaticamente interrompida por outros componentes sentenciais, conforme exemplificado em (25).
} 
(24) (...) que a Congregação tomasse uma deliberação sobre o seguinte: (...) (A, $16 / 11 / 1895)$

(25) Levo ao vosso conhecimento que o professor d'esta Escola , [snr.] Macedo Soares fez ao gabinete de physica e laboratorio de chimica donativo dos seguintes objectos: (...) (C, 9/10/1894)

Tais verificações apontam que o tipo verbal, bem como a forma dos argumentos do verbo atualizado, têm certa relevância no condicionamento da ordem em textos formais do período em estudo. Além destes, porém, outros fatores, ligados à natureza do sujeito, podem estar relacionados a essa questão.

\subsubsection{Peso do Sujeito}

Vários estudos acerca do PB atual atestam que a presença de um sujeito constituído por SN extenso ou pesado contribui para a posposição desse constituinte ao verbo (Cf. Naro \& Votre, 1999; Berlinck, Duarte \& Oliveira, 2009).

Para uma definição mais precisa do conceito de extensão ou peso, adotamos o critério de Berlinck, Duarte \& Oliveira (2009: 112) ${ }^{104}$, que propõem ser o SN pesado "um sintagma longo, com modificadores e complementos do nome, que podem ser

\footnotetext{
${ }^{104}$ Naro e Scherre (2007) adotam o princípio da saliência fônica. Visto que esse e outros trabalhos da mesma linha tomam amostras de fala ou de representação de fala, a correlação com o aspecto fonético realmente se faz relevante. Neste estudo optamos pelo fator referencial, tendo em vista a natureza escrita do corpus.
} 
representados por sintagmas simples ou sentenciais", conforme exemplificado pelas autoras:

a. Isso foi o que decidiram os deputados da bancada ruralista recém-chegados.

b. Só dormiram os meninos que chegaram do passeio ao Parque Ecológico.

Os nomes próprios, muito frequentes no corpus, foram analisados como elementos [-pesados], pois embora sejam longos, remetem a um único elemento e não apresentam informação adicional sobre o mesmo, como ocorre em (a) e (b) acima. E, por haver um emprego elevado de abreviações nesses nomes, a avaliação correta da variável poderia ser dificultada. Nas amostras abaixo se encontram representados exemplos de sujeito [+pesado] e [-pesado], respectivamente, encontrados no corpus. O primeiro deles assim se caracteriza por apresentar-se acompanhado de modificadores, ao passo que o segundo constitui-se de apenas um substantivo acompanhado de determinante:

(26) A prova escripta do oppositor Eduardo Carlos Pereira, conquanto revele em grau elevado a capacidade profissional de seu autor, resente-se de pequenos senões, que não seriam tomados em consideração si o julgamento fosse absoluto e não relativo. (C, 25/4/1894)

(27) Absolutamente não contem o parecer a menor referencia pessoal ao autor da proposta sob o ponto de vista de ser-lhe feita qualquer censura. (A, $19 / 11 / 1895)$

Como se pode verificar em (26) e (27), há tanto ocorrências de sujeitos antepostos [+pesados] como pospostos [-pesados]. E, contrariando os resultados de 
outras pesquisas, não parece haver, no corpus analisado, forte correlação entre a ordem realizada e o fator em questão. Verificamos, para os sujeitos anteposto e posposto, $35,7 \%$ e $37,8 \%$ de frequência do traço [+ pesado], respectivamente. A equivalência desses valores é um índice da marginalidade do fator em questão como condicionante de VS nas amostras analisadas.

O sujeito mais pesado, conforme apontam os estudos funcionalistas, oferece maior dificuldade de recuperação de conteúdo informacional. Portanto, devido a esta característica desse sujeito, é provável que seja mais atuante como favorecedor de VS em textos de produção oral e menos em textos escritos, cuja natureza facilita o acesso a conteúdos anteriores. Tal particularidade minimiza a atuação do fator como condicionante de variação no corpus analisado.

Entretanto, o destaque fica por conta dos verbos monoargumentais, nas atas. Grande parte dos sujeitos atualizados em ocorrências VS constituía-se de sequências de nomes, como no exemplo a seguir:

(28) não compareceram os $\mathrm{Snr}^{\mathrm{s}}$. - $\mathrm{D}^{\mathrm{rs}}$. José Machado de Oliveira, $\mathrm{D}^{\mathrm{r}}$. Carlos $\underline{\text { Reis, }} \mathrm{D}^{\mathrm{r}}$. Odilon Goulart, $\mathrm{D}^{\mathrm{r}}$. Henrique J. de Lacerda, Carlos Lentz de Araujo, D $^{r}$. Godofredo J. Furtado, J. E. de Macedo Soares, M. Cyridião Buarque, e D. Felicidade Perpetua de Macedo. (A, 9/12/1895)

Esse tipo de ocorrência apresenta um caráter peculiar, não se enquadrando no critério de sujeito pesado adotado na análise. Nascimento (1994) propõe que orações VS com verbos inergativos e inacusativos do PB atual recebem "interpretação de lista". Segundo essa proposta, o sujeito é interpretado como parte de um conjunto, o que ocorre diante da "relação de [+/- inclusão] num dado grupo de referência. Um dos 
termos dessa relação, o elemento [+] ou [-] incluído, deve ser dado pelo $\mathrm{NP}^{105}$ que aparece na posição pós-verbal" ${ }^{\text {106 }}$.

A constituição dessas estruturas pode também ser interpretada nos termos da concepção saussuriana de sintagma e paradigma. Sujeitos como o de (26), abordados na subseção anterior

(26) A prova escripta do oppositor Eduardo Carlos Pereira [...]

estabelecem-se em eixo sintagmático, posto que são construídos linearmente por meio da relação entre o núcleo e os outros elementos do sintagma, relação estabelecida em presença.

Por outro lado, o sujeito que admite "interpretação de lista" como o de (28) é concebido como sendo um elemento de um conjunto. Requer, portanto, uma leitura paradigmática, pois evoca outros elementos a ele equivalentes, com os quais estabelece relação em ausência ${ }^{107}$.

\subsubsection{Estatuto Informacional do Sujeito}

Os sujeitos [+ pesados], justamente por serem mais extensos, normalmente se destacam como importantes portadores de informação, como pudemos verificar em (8). Esta propriedade os correlaciona a uma outra, referente ao estatuto informacional do sujeito.

\footnotetext{
${ }^{105}$ Mantivemos a notação NP (Noun Phrase) em lugar de SN (Sintagma Nominal) por se tratar de uma citação.

${ }^{106}$ Apud Pilatti, 2006: 162.

${ }^{107}$ Saussure, F. (1969). Relações sintagmáticas e relações associativas. In: Curso de Linguística Geral. SP: Cultrix-Edusp, p.142-147.
} 
Estudos têm demonstrado que sujeitos de carga informacional nova são realizados preferencialmente em posição pós-verbal, o que foi atestado por Berlinck (1989) em textos do século XVIII. Em seu trabalho, a autora analisa o fator como o mais forte condicionante da inversão naquele recorte temporal. Estudos sobre o PB atual, particularmente os de viés funcionalista, indicam a permanência da atuação desse elemento discursivo (cf. Pontes, 1987; Spano, 2002; entre outros).

A carga informacional nova do sujeito tem sido não somente associada à ordem verbo-sujeito, como também a sujeitos [+ pesados]. Posto que uma informação nova requer especificações, mais do que uma informação dada, sendo por isso mais extensa; e que a ordem VS é privilegiada na atualização de sujeitos que trazem informação nova ao discurso, tem-se uma coincidência de elementos que leva à associação entre o sujeito [+pesado], novo, e a ordenação VS.

Para a análise do corpus assumimos como novo o sujeito apresentado no texto pela primeira vez ${ }^{108}$. Em nosso corpus, no entanto, assim como foi observado com relação ao peso do sujeito, atestamos não ser pertinente o estatuto novo do sujeito como elemento favorecedor da ordem VS. Segue exemplo de sujeito com referente dado:

(29) Em dacta de 19 de julho do corrente anno sollicitei do Governo do Estado a entrega ao porteiro d'esta Escola, Francisco de Paula Marques, da quantia de trezentos e cincoenta mil reis (350\$000) para as despezas á effectuar com a mudança da Escola do antigo para o novo predio.

\footnotetext{
${ }^{108}$ Consideramos na classificação do corpus duas categorias de sujeito no que se refere ao estatuto informacional: dado e novo, sendo que este último tipo é comumente subdividido em outras categorias. Com base em Votre (1996), que aponta, de um lado, a correspondência entre a ordem SV e sujeito evocado; e de outro, entre VS e sujeito disponível, novo parcial ou novo total (Votre, 1996: 116), assumiremos uma distinção sintética, fundamentada no critério de inserção ou não-inserção prévia, no discurso, da informação codificada pelo constituinte sujeito.
} 
A referida quantia foi recebida no Thesouro do Estado em dacta de 21 de Julho de 1894.

Perante esta Directoria prestou contas o referido Porteiro, segundo vereis pelos documentos junctos, e para o devido effeito, peço-vos, que ordeneis sejão as respectivas contas julgadas prestadas. (C, 19/10/1894)

Tal constatação justifica-se ao se levar em conta fatos como o de que os textos tomados como fonte para nosso corpus (cartas oficiais e atas da Congregação) eram produções de circulação limitada, quase nula, consistindo, de certo modo, em uma forma de organização interna da instituição. Talvez a ausência de um objetivo persuasivo e a ausência de necessidade de manter o interesse do ouvinte/leitor, como ocorre em outros gêneros, tenham feito com que os textos analisados fossem pouco propícios à atuação do estatuto informacional como fator condicionante de variação.

\subsubsection{A semântica do sujeito}

A partir da análise de alguns dos fatores linguísticos possivelmente relacionados à colocação pré ou pós-verbal do sujeito, pudemos observar certa pertinência do tipo verbal, considerando sua transitividade e tipo de argumento requerido. Quanto aos fatores ligados ao sujeito, como 'peso' e 'estatuto informacional', não se observou correlação que os destacasse como elementos importantes na configuração da ordem.

Com o intuito de verificar a possível correlação entre propriedades do sujeito e a formação da ordem sentencial, pretendemos explorar alguns outros aspectos desse constituinte, mais particularmente relacionados à semântica das atualizações. Seguindo 
a pista de estudos anteriores sobre ordem (Spano, 2008; Berlinck, 1989; Tarallo \& Kato, 2006; e outros), buscaremos descrever os dados com relação a (i) animacidade, (ii) definitude e (iii) agentividade do sujeito.

\subsubsection{Animacidade}

O primeiro dos três aspectos a serem analisados, a animacidade, diz respeito à propriedade de ser vivo ou ser capaz de dar início a ações, sejam elas individuais ou coletivas (Spano, 2009: 98). Assim, classificam-se como [+animados] termos como $o$ professor, os alunos, o servente; referências com nomes próprios; além de nomes que representem associações que possam empreender ações, como a Congregação. Os dados abaixo exemplificam sujeito [+animado] designando indivíduos (30) ou conjuntos de indivíduos (31):

(30) Sendo, porem, certo que como servente prestou Ambrosio Antonio dos

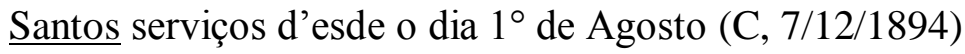

(31) A commissão examinou os textos legaes e regulamentares existentes sobre o assumpto (...) (A, 3/9/1895)

O índice relacionado a esse fator indica, para sujeito pré-verbal, 50,94\% [+animado]. As expectativas com relação ao sujeito pós-verbal seriam de uma aplicação ainda menor do traço, visto que a literatura tem mostrado que sujeitos pós-verbais são 
preferencialmente inanimados. No entanto, os sujeitos pós-verbais animados correspondem a $58,50 \%$.

\subsubsection{Definitude}

Diante desses resultados não muito esclarecedores a respeito da força do traço animacidade na disposição do sujeito sentencial, voltamos nosso olhar para a definitude do sujeito, com base no pressuposto de que o sujeito pós-verbal tende a ser indefinido. Consideramos [+ definido] o constituinte acompanhado de determinante definido com referência específica (32), e nomes próprios (33). No caso dos pronomes, a definição ficou por conta do fato de ter um referente determinado, como em (34).

(32) (...) e que a revisão geral das materias já estudadas é practicavel d'esde que o curso normal esteja regularisado (A, 2/4/1895)

(33) Houve, porem, demora da nomeação e da celebração do contracto de modo que só entrou regularmente em exercicio do cargo de porteiro o cidadaõ Antonio Benedicto Branco á 25 de Agosto, e Ambrosio Antonio dos Santos como servente na mesma dacta. (C, 12/9/1894)

(34) (...) venho sollicitar a expediçaõ de ordem para que seja entregue pelo Thesouro do Estado ao respectivo porteiro Francisco dePaula Marques a quantia de trezentos i cincoentamil reis (Rs 350.000) da qual prestará o mesmo contas ao Thesouro do Estado opportunamente. (C, 19/7/1894) 
Os SNs com determinante definido e sem referência específica foram analisados como [- definido], como em (35), exemplo no qual o SN o aluno não remete a um aluno em especial, mas a qualquer aluno da Escola Normal.

(35) A lei no 169 em seu art. 30 (reproduzido no art. 397 do Reg. de 27 de Novembro de1893) só trata dos annos inferiores ao ultimo, prescrevendo que $\underline{0}$ alumno é obrigado á repetir no anno seguinte as materias em que tiver obtido notas desfavoraveis (...). (A, 3/9/1895)

Além destes, listam-se contextos tipicamente classificados como não definidos, com sintagmas encabeçados por artigo ou pronome indefinidos,

(36) (...) tanto mais quanto nenhum dos membros da comissão conhece pessoalm $^{\text {te }}$. qualquer dos candidatos em questão. (C, 25/4/1894)

ou de referência coletiva, com baixa especificidade:

(37) Observou, então, o Snr. Director que nunca tendo havido na Escola um facto de indisciplina collectivo, e achando-se já ausentes da Escola a maior parte dos alumnos dos $1^{\circ}$ e $2^{\circ}$ annos, que retiráram se sem haver feito nenhuma manifestação de desagrado, parecia-lhe que não se devia attribuir a autoria da carta á nenhum alumno. (A, 12/12/1895) 
Com base nesses critérios, procedemos à classificação e quantificação dos dados. Contrariando os resultados apontados em estudos anteriores, atestamos percentuais altíssimos de sujeito [+ definido] para as duas posições analisadas, pré e pós-verbal (90,57\% e $89,80 \%$, respectivamente).

Esses resultados, ao lado dos relacionados à animacidade do sujeito, podem inicialmente confundir o pesquisador, obscurecendo a análise do objeto linguístico. É necessário, portanto, um olhar mais acurado sobre os dados do corpus para melhor compreendê-los. A expectativa de que os sujeitos pospostos fossem primordialmente [animados] e [- definidos] não se concretizou nos dados provavelmente em virtude da natureza do conteúdo dos textos fonte da pesquisa. Os textos da ENC fazem referência principalmente aos eventos relacionados à Escola e, por consequência, aos sujeitos neles envolvidos, tais como professores, alunos e serventes. Estes, por sua vez, são frequentemente referidos pelo sujeito sintático, que por este motivo apresenta alto índice do traço [+ animado]. Ademais, como em geral remetem a indivíduos específicos, o caráter [+definido] dessas construções acaba por apresentar-se também em grau elevado.

\subsubsection{Agentividade}

Temos, portanto, que os sujeitos pós-verbais no corpus desta pesquisa são, assim como os pré-verbais, majoritariamente [+animados] e [+definidos]. Estes traços semânticos usualmente aparecem associados a um caráter agentivo marcado (Berlinck, 
1989; Pontes, 1987). Assim, um elemento animado e definido é, em geral, [+agente] ${ }^{109}$, causador de alguma ação (Mioto et alii, 2007:126).

Buscamos verificar se esta propriedade se aplica aos sujeitos sentenciais de nosso estudo, particularmente os pós-verbais. Nosso intuito, com isto, foi verificar se o constituinte analisado, quando posposto ao verbo, consiste em um sujeito propriamente dito ou seria um argumento interno [-agente], característica das inversões inacusativas.

Ao considerar todos os contextos levantados, atestamos 44,9\% de sujeitos pósverbais agentivos. Porém, tal resultado sofre a interferência das construções passivas e copulativas, de sujeito categoricamente [-agente]. Excluindo essas ocorrências, obtémse $70,21 \%$ de sujeitos pospostos [+agente] em contextos de verbos mono e biargumentais.

(38) Em seguida fez o cidadão Director a exposição do motivo da convocação extraordinaria da Congregação - declarando o seguinte: (...) $(\mathrm{A}, 16 / 10 / 1895)$

(39) Peço-vos que vos digneis providenciar para ser feito o pagamento da referida quantia de Rs 2:527\$300 ao Porteiro desta Escola ao qual já passaram os fornecedores recebidos de confiança. (C, 19/11/1894)

Os cerca de $30 \%$ de dados com traço [-agente] ocorrem com verbos que não designam propriamente uma ação realizada pelo sujeito:

(40) Quando, porem, não houvesse contra a pretenção da Requerente a expressa e terminante disposição do citado $\$ 4^{\circ}$ do art. 122 e pudesse ser pelo Governo

\footnotetext{
${ }^{109}$ Adotamos aqui os conceitos semânticos de agentividade e agente sem adentrar na questão temática por serem tais conceitos suficientes para a análise que desenvolvemos aqui.
} 
attendida, nada lucraria a requerente em ser admittida ao exame de historia do Brazil. (C, 14/12/1894)

(41) A Congregação da Escola Normal de S. Paulo, lamentando o excepcional e inqualificavel desacato que com ella soffreu o Director, e manifestando á este seu pleno apoio no desaggravo [justo] que o caso exige (...) (A, 12/12/1895)

Em tais ocorrências, os verbos atualizados pertencem a categorias que selecionam argumento não-agentivo, tais como a dos avaliativos, epistêmicos e perceptivos.

Em suma, com relação às propriedades semânticas do sujeito, verificamos que o sujeito posposto nos textos da ENC caracteriza-se por apresentar um ser definido, animado e agentivo, tratando-se, portanto, de argumento externo em posição pós-verbal, e não inversão inacusativa, característica do PB atual.

\subsubsection{A ordem e a codificação de juízos tético e categórico: uma analogia}

A caracterização semântica do sujeito apresentada na subseção anterior revelou alguns aspectos desse constituinte no corpus deste estudo. Com o intuito de descrever também as diferenças de expressão relacionadas a construções com sujeito anteposto e posposto, nos voltamos para as noções de juízo tético e categórico.

Diversos estudos sintático-comparativos têm demonstrado a possibilidade de codificação sintática de juízos e descrito suas formas de realização. Kuroda (1972) ${ }^{110}$

\footnotetext{
${ }^{110}$ Conforme apresentamos no Capítulo 2.
} 
propõe que, em Japonês, as partículas ga e $w a$ estejam associadas aos juízos tético e categórico, respectivamente. Tendo como pressuposto a análise desse autor, Kato $(1988)^{111}$ analisa as construções inacusativas ${ }^{112}$ do PB atual. A autora propõe que o juízo tético seria representado sintaticamente pela ordem VS e o juízo categórico pela ordem SV.

Considerando que o juízo tético está relacionado à descrição de um evento sem, no entanto, enfatizar seus participantes; e que, em asserções de juízo categórico, diferentemente, há ênfase nos participantes do evento, temos, nos seguintes dados de Kato $(1988)^{113}$, duas sentenças que, embora similares, representam juízos diferentes:
a. As cartas chegaram. (= NP wa)
b. Chegaram as cartas. (= NP ga)

A sentença em (a) é interpretada como expressão de juízo categórico, sendo o elemento as cartas proeminente no discurso. A sentença seria adequada em um contexto em que houvesse uma expectativa com relação a chegada de certas cartas e, tendo elas chegado, o indivíduo que as aguardava seria informado com a expressão em (a). Numa situação hipotética em que não seja esperada uma carta específica, a expressão em (a) provavelmente provocaria estranhamento no interlocutor, e possivelmente seria seguida do comentário "Que cartas?”.

No entanto, caso chegassem cartas mas não houvesse nenhuma expectativa com relação a elas, isto é, se fosse a correspondência comum do dia, a expressão adequada para comunicar seu recebimento seria a de (b). Relacionada a um juízo tético, esta sentença seria empregada para descrever o evento de recebimento das cartas, estando

\footnotetext{
${ }^{111}$ Apud Britto, 1998.

${ }^{112}$ Para a codificação sintática de juízos com verbos transitivos e intransitivos no PB atual vide Britto, 1998.

${ }^{113}$ Apud Britto, op. cit., p.22.
} 
estas envolvidas na situação descrita, mas não evidenciadas, não apresentando, portanto, a função de tópico ${ }^{114}$.

Correlação similar a esta parece haver nas amostras de nosso corpus ${ }^{115}$, não restrita aos verbos inacusativos, mas aplicada também a outros contextos ${ }^{116}$. Inicialmente, observamos que os textos apresentavam basicamente dois tipos de conteúdo. O primeiro deles referente a ações de praxe da Escola, tais como tomar posse de cargo, enviar ao Governo contas de despesas, prestar compromisso, declarar uma decisão, entre outras. São atividades típicas do cotidiano da instituição, ou com caráter de oficialidade. (42) a (44) exemplificam esses contextos:

(42) Declarado assim o motivo da reunião pôz o cidadão Director em discussão o assumpto. (A, 11/3/1895)

(43) Levo ao vosso conhecimento para o devido effeito, que, n'esta data reassumio o exercicio do cargo de directora da Escola Modelo Miss Marcia P.Browne. (C, 12/6/1894)

(44) $\underline{\text { Pedio }}$ por sua vez a palavra o $\mathrm{D}^{\mathrm{r}}$. J. Benevides (A, 19/11/1895)

Similarmente ao proposto por Kato (1988) para os verbos inacusativos no PB atual, podemos perceber a baixa saliência discursiva dos SNs sujeito dos verbos em

\footnotetext{
${ }^{114}$ Adotaremos aqui o conceito de tópico como o referente sobre o qual se faz uma declaração, não devendo ser confundido com tópico discursivo.

${ }^{115} \mathrm{Na}$ presente análise, não assumiremos literalmente a noção de juízo. Adotamos esta concepção devido à analogia que é possível estabelecer entre a semântica dos juízos e a interpretação dos dados do corpus, particularmente no que tange à maior ou menor proeminência dos participantes do evento expresso. No entanto, não se deve analisar as amostras deste estudo como representações de juízo no sentido estrito de sua concepção.

${ }^{116}$ Vale destacar que a codificação de juízos com verbos transitivos e intransitivos no PB atual se faz pela distinção entre construções SV e com resumptivo sujeito para os juízos tético e categórico, respectivamente (cf. Britto, 1998). No entanto, não temos notícia do uso dessas formas no século XIX. E mesmo que já existissem, certamente não seriam adequadas ao registro culto escrito - como ainda não são -, o que tornaria necessário que a distinção lógico-semântica dos enunciados fosse codificada de outro modo, que, conforme propomos aqui, seria a colocação pré ou pós-verbal do sujeito.
} 
destaque, provavelmente advinda do caráter dos conteúdos comunicados nesses trechos. Em (42), o fato de ter sido o Diretor quem deu abertura à discussão do motivo da reunião não se mostra relevante, até por ser esta uma prática das reuniões e, portanto, óbvio que ele é quem o faria. O que importa, no trecho, é remeter ao 'assunto que motivou a reunião', o qual é referido no início da sentença, retomado no final e desenvolvido nos parágrafos seguintes. De certo modo, pode-se considerar o trecho em questão uma estratégia para inserção do tópico discursivo 'assunto da reunião', sobre o qual são posteriormente feitas discussões. Essa leitura propicia a interpretação como sendo de juízo tético.

A interpretação das outras duas amostras pode ser conduzida na mesma direção. Em (43), é pertinente o fato de o cargo ter sido reassumido, não importando enfatizar quem o fazia, até por não se tratar de uma nova diretora ou docente, evocando o juízo tético. Esse dado deixa transparecer o caráter oficial e burocrático que permeava esses registros, constituindo parte deles e manifestando-se linguisticamente de modo peculiar.

A expressão 'Pedio a palavra', em (44), é outro exemplo de como as atividades da rotina institucional e burocrática, com suas práticas e dinâmicas próprias, se expressam sintaticamente através da ordem VS, a qual parece apresentar, no texto, um ambiente de estabilidade do qual emergem e se efetuam atos que se destacam nesse contexto. Esse modo de ordenação dos constituintes contrasta com o de sentenças em que são relatados atividades e fatos relacionados à Escola, porém não típicos de suas práticas convencionais, apresentados preferencialmente sob a ordenação sujeito-verbo.

A estes exemplos somam-se inúmeros outros, com destaque para o uso das passivas analíticas expressando práticas da rotina escolar administrativa. Excluímos da análise quantitativa grande número de ocorrências VS atualizadas nessa forma verbal 
que remetiam a atividades da instituição (como "contratar", "pagar", "nomear") e a atividades efetuadas nas reuniões (“ler”, “aprovar”, “propor”, “decidir/resolver”, etc).

Assim, enquanto os conteúdos ligados ao cotidiano escolar são apresentados em ordem VS, os temas atípicos ou que fogem à regularidade e estabilidade das atividades normais parecem ocorrer preferencialmente sob a ordenação SV. Esta proposta pode ser exemplificada pela comparação entre dois trechos de cartas referentes ao concurso para professor da cadeira de português.

Na primeira carta constam as determinações e decisões relativas ao modo como o concurso deverá ser realizado. Portanto, tratam-se basicamente de instruções nas quais muitos elementos têm um caráter genérico, não específico. Devido a esse caráter do registro, não importa ressaltar certos elementos do processo, tais como os concorrentes à vaga. Assim, em tal registro, em que não se enfatizam os participantes, atualiza-se sujeito posposto:

(45) Em dia posterior ao da terminaçaõ da prova oral, na hora designada,

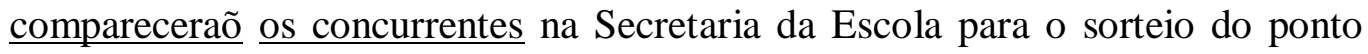
para a prelecçaõ; o qual será extrahido da respectiva urna pelo primeiro candidato inscripto em presença do Director da Escola. (C, 31/3/1894)

Em uma segunda carta a respeito do concurso, este já se havia realizado. O registro passa, portanto, a destacar os participantes do evento, especialmente por se tratar de uma situação em que tais indivíduos se encontravam em concorrência. Diferentemente do que foi visto em (45), observa-se o uso da ordem sujeito-verbo, inclusive com verbos pronominais, como em (46):

(46) Os dois oppositores approvados conservaram-se sempre em todas as provas oraes no mesmo ponto de igualdade. (C, 25/4/1894) 
Observe-se que verbos pronominais com se como o de (46), ao lado de verbos inacusativos, copulares e passivas, tendem a favorecer a atualização de VS (Berlinck, Augusto e Scher, 2001: 224). No entanto, a ordenação atualizada privilegia discursivamente os participantes do evento, no caso, os candidatos ao concurso.

Esse mesmo recurso foi utilizado em outro momento do texto. Sendo necessário destacar a diferença de desempenho dos candidatos para justificar o resultado das provas, atualiza-se novamente o sujeito pré-verbal, posição que atribui a esse constituinte um caráter proeminente e leva à sua interpretação como tópico.

(47) Si o primeiro, Carlos Lentz de Araújo, tanto na arguição como na prelecção, mostrou maior somma de conhecimentos, o segundo, Eduardo Carlos Pereira, contrabalançou essa superioridade na exposição methodica do objecto do ponto sorteado para a prelecção e na applicação pratica da theoria exposta, como tivestes occasião de pessoalmente verificar. (C, 25/4/1894)

Esses contextos mostraram-se também frequentes nas atas, cujo índice de SV é bastante próximo ao das cartas, como mostramos na Tabela 2. Em (48) destacamos o trecho de ata em que se discutia o comportamento impróprio de um aluno, contexto em que o sujeito se mostra proeminente:

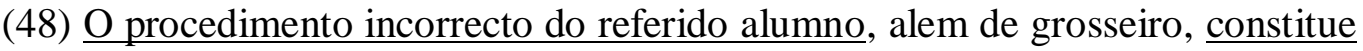
verdadeira falta disciplinar em vista das disposições regulamentares, por ser um desrespeito á um lente no exercicio de suas funcções e como tal deve ser punido. $(A, 19 / 11 / 1895)$ 
Há, portanto, dois enfoques discursivos distintos com reflexos na estrutura sintática. O primeiro deles consiste na referência a evento sem destaque para os elementos nele envolvidos, analogamente ao que ocorre em (45), dado que apresenta a descrição dos procedimentos de concurso para professores, e de quando os candidatos deveriam comparecer para realização das provas. No entanto, não se salientam os participantes do processo, que nem mesmo são indivíduos específicos, dado que, à data do registro, o concurso ainda não havia ocorrido. Manifesta-se então, nesses contextos, a posposição do sujeito, codificação sintática que situa esse constituinte em uma espécie de segundo plano no discurso. De outro lado, verificamos a ênfase nos participantes realizada preferencialmente com sujeito pré-verbal.

\subsection{Cruzando linhas}

Dentre os fatores expostos nas subseções anteriores e considerados como possíveis favorecedores de ordenação VS, alguns se mostraram mais relevantes. Como vimos, a caracterização do verbo segundo seu número de argumentos manifestou certa relevância na determinação da ordem. Para os verbos copulares, apontados como favorecedores de VS, foi observada uma produtividade considerável dessa ordem, em torno de 30\%. Essa tendência é ainda mais acentuada, com índice de $70 \%$, com os predicados monoargumentais, importante contexto de atualização no PB atual, em que essa ordem já não é tão produtiva.

Por sinal, a análise de Berlinck (1989) para o século XX aponta a transitividade verbal como o fator mais importante para a variação da ordem nesse período. Em seu estudo, a autora tomou fontes datadas de 1850 e 1987 para constituir os corpora dos 
séculos XIX e XX. O material de nossa pesquisa, por sua vez, situa-se entre esses períodos, mais próximo, no entanto, do primeiro deles. Considerando a proposta de reanálise da autora, ou seja, de re-hierarquização dos fatores ao longo dos séculos, podemos aventar a hipótese de que os nossos resultados refletem um momento de transição entre dois grupos distintos de princípios determinantes de ordenação, em que esse condicionamento já começava a ganhar força.

Além da transitividade, destacamos especialmente a maior ou menor saliência do constituinte sujeito no texto, com base na distinção entre juízos tético e categórico. De natureza menos formal, esse fator mostrou-se um elemento importante na colocação do sujeito na sentença: sujeitos proeminentes são preferencialmente antepostos, e sentenças em que o destaque está no evento são caracterizadas pela posposição do sujeito. Essa interpretação revela a motivação não apenas formal, mas discursiva, para a organização da ordem.

Deste modo, observamos que as realizações com sujeito posposto, já pouco usuais no vernáculo, manifestaram-se em contextos linguisticamente favoráveis, motivadas especialmente pelo aspecto semântico. O diferencial mais relevante observado nos dados refere-se à alta produtividade de sujeito pós-verbal, em termos quantitativos, se comparada com os resultados obtidos para o vernáculo (Berlinck, 1989; Torres Morais, 1993).

Não se enquadrando na descrição do vernáculo do período, verificamos se a posposição do sujeito nos textos da ENC estaria pautada em modelos de indivíduos considerados cultos. Em estudo ${ }^{117}$ sobre a ordem em textos de Eduardo da Silva Prado (ESP) e Luís Pereira Barreto (LPB), ligados à(s) elite(s) e intelectualidade(s) paulistas da virada do século, observamos um elevado índice de posposição do sujeito ao verbo,

\footnotetext{
${ }^{117}$ Oliveira et alii (no prelo).
} 
$32,7 \%$ e $35,4 \%$, respectivamente. Entretanto, esses percentuais são ainda inferiores aos dos textos produzidos na ENC, de 48,04\%. Uma interpretação alternativa está na aproximação do padrão linguístico europeu e distanciamento da língua do restante da população garantindo, assim, a distinção e autoridade cultural do grupo que a adotava (Pagotto, 1998: 55).

Para verificar um possível espelhamento em Portugal, analisamos a posição do sujeito sentencial em amostras de cartas de alguns escritores, figuras de relevo das letras no século XIX: os portugueses Camilo Castelo Branco (1825-1890) e Eça de Queiróz (1845-1900). Como contraparte para a análise, tomamos também amostras de cartas dos brasileiros Álvares de Azevedo (1831-1852), Machado de Assis (1839-1908) e Euclides da Cunha (1866-1909).

O levantamento dos dados apresentou os seguintes resultados:

Tabela 5: Frequência de sujeito posposto em cartas de escritores brasileiros e portugueses

\begin{tabular}{|c|c|c|}
\hline Data do texto & Autor & $\begin{array}{c}\text { Sujeito } \\
\text { posposto }\end{array}$ \\
\hline 1848 a 1849 & Álvares & $35 \%$ \\
\hline 1862 a 1886 & Machado & $15 \%$ \\
\hline 1890 a 1894 & Euclides & $18 \%$ \\
\hline 1879 a 1882 & C. Branco & $19 \%$ \\
\hline 1890 a 1894 & E. Queiroz & $11 \%$ \\
\hline
\end{tabular}

Os índices obtidos a partir de cartas de escritores mostram, no português do Brasil, a maior incidência de posposição do sujeito em meados do século XIX, representada por Álvares de Azevedo, seguida de uma redução no emprego dessa forma. As produções dos brasileiros do final do século apresentam maior proximidade com as dos autores portugueses no quesito ordem de constituintes. A partir desses dados não é 
possível dizer que a ENC se pautava em Portugal, visto que o percentual dos brasileiros é o mesmo, o que, por sua vez, os aproximava do vernáculo local.

Entretanto, o quadro muda quando se sai da órbita desses literatos, aparentemente mais próximos do vernáculo. A comparação dos resultados desses escritores aos dos intelectuais paulistas constantes na Tabela 6 deixa nítida a distância existente entre os registros aqui analisados no que se refere à ordem de constituintes, contrariando a hipótese de que o PB culto teria como modelo o português europeu $\operatorname{moderno}^{118}$.

Tabela 6: Frequência de sujeito posposto em textos do PB culto

\begin{tabular}{|c|c|c|}
\hline Data do texto & Autor & $\begin{array}{c}\text { Sujeito } \\
\text { posposto }\end{array}$ \\
\hline 1901 & E.S.Prado & $32,7 \%$ \\
\hline 1901 & L.P.Barreto & $35,5 \%$ \\
\hline
\end{tabular}

Observamos, a partir dos números da Tabela 6, certa proximidade entre o uso da ordem pela intelectualidade paulista de fins do XIX e por Álvares de Azevedo. Essa proximidade pode ser explicada em função do meio social, pois se trata de um membro de família da elite paulistana, como Barreto e Prado.

Contrariamente, distanciavam-se de Machado e Euclides, intelectuais prestigiados já no período. No entanto, ambos eram oriundos de classe social menos favorecida, tendo ascendido no campo cultural. Esse histórico parece ter interferido no distanciamento entre a linguagem destes e a dos intelectuais paulistas ${ }^{119}$.

\footnotetext{
${ }^{118}$ A esse propósito, tem sido demonstrado que o PE atual se aproxima do PB no que se refere à ordem de constituintes em diversos aspectos (Spano, 2009).

${ }^{119}$ Uma questão interessante para pesquisa é a comparação de textos da elite de São Paulo e Rio de Janeiro.
} 
Aliás, questiona-se se Portugal, no século XIX, era tomado como fonte cultural pelo Brasil ${ }^{120}$. Apesar de o foco, nesse período, estar voltado para a Europa, o principal centro irradiador de cultura era a França, seguida de outras nações como Alemanha e Inglaterra. Ademais, a frágil condição política e econômica de Portugal no período desfavorecia que fossem tomados como modelares os elementos de sua cultura.

Em quem estariam, então, se espelhando a elite intelectual (Pereira Barreto e Eduardo Prado) e os autores dos textos da Escola Normal, em cuja escrita se observa uma frequência incomum de sujeitos pós-verbais? Inicialmente, podemos supor que se trata de aspecto coercitivo dos gêneros analisados. Somando-se a essa hipótese (e sem excluí-la), a crítica de João Ribeiro (1921) dá-nos uma pista para elucidar essa intrigante questão ao defender o uso da língua genuinamente brasileira, independente do português europeu. Segundo o gramático, a língua nacional não deveria ser a sombra da língua de Portugal, e sim assumir e valorizar suas próprias estruturas. Essa atitude refletiria supostas independência e liberdade linguísticas, referendando a independência política do Brasil em relação a Portugal e a 'liberdade individual' traduzida pela abolição dos escravos:

Parece todavia incrível que a nossa Independência ainda conserve essa algema nos pulsos, e que a personalidade de americanos pague tributo à submissão das palavras. [...] A verdade, entretanto, é que normalmente dois seres não realizam a sua própria evolução, agarrados como xifópagos, um às carnes do outro. Em qualquer caso, livre-nos Deus dessa teratologia. (op. cit.: 51, 57)

\footnotetext{
${ }^{120}$ Segundo o Prof. Dr. Carlos Bacellar (c. p.), a elite brasileira consumia produtos portugueses
} (alimentos, vinhos, instrumentos musicais), elementos materiais, mas não adotava as ideias de Portugal. 
A distância entre as duas nações no campo linguístico é marcada pela nãoincorporação da "linguagem contemporânea dos lisboetas". No entanto, esse afastamento deve ser matizado, uma vez que o alicerce do idioma nacional era buscado no português clássico:

Nós outros, porém, cultivamos a língua clássica, versamos com maior frequência os quinhentistas e seiscentistas, e nestes (que representam a flor da literatura), achamos o aroma da vernaculidade e da pureza do idioma. (op.cit: 182, grifo nosso)

Essa concepção indicia a "tendência arcaizante" do português brasileiro culto (op.cit: 184), que possivelmente se espelhava na língua de Portugal do período áureo, do Império lusitano, e momento de 'fundação' do Brasil colonial. Apesar de João Ribeiro (1921) associar o português do Brasil à linguagem clássica, é notório que o domínio dessa variedade, buscada nos autores quinhentistas e seiscentistas, requeria certo grau de instrução da qual a maior parcela da população estava privada.

Configurava-se, deste modo, um processo de exclusão cultural associado ao de exclusão sócio-econômica, na medida em que a cultura letrada era acessível a uma minoria da população e consistia num dos principais meios de galgar condições mais privilegiadas na sociedade. Nesse sentido, destaca-se a importância da Escola como formadora de um habitus que tende a se afastar do vulgar, marcando a distinção e reproduzindo, assim, uma hierarquia social e cultural.

Presente nos exames de alunos e concursos da Escola Normal, a linguagem quinhentista permeava também outros núcleos da cultura letrada. Na Academia de Direito, essa fonte encontrava-se não só na literatura camoniana, mas nos textos jurídicos. O Brasil, apesar de sua "longa tradição codificadora" (Venosa, 2004:230), 
teve seu primeiro código, o Código Penal ${ }^{121}$, publicado somente no final do século XIX (1890). Passaram-se ainda vinte e seis anos até que fosse publicado o primeiro Código Civil, já em 1916. Até então, o Direito brasileiro adotava os parâmetros legislativos portugueses, que vigoravam no Brasil desde 1500 e se apoiavam nas Ordenações Afonsinas (1446), Manuelinas (1521) e, posteriormente, Filipinas (1603). O estudo desses textos pelo bacharel, somado ao de textos burocráticos, certamente interferia na formação de sua linguagem, particularmente a escrita.

Deste modo, o conservadorismo linguístico da Escola Normal tinha como fontes principais a literatura tradicional e a Academia de Direito, representada pelos bacharéis, cuja formação se pautava, em grande parte, em textos quinhentistas. A valorização do padrão linguístico clássico na escrita culta representa, na linguagem, o conservadorismo dos grupos que dela se utilizavam - como a equipe dirigente da ENC. Conservadorismo este igualmente motivador, em âmbito econômico, de processos de desigualdade e exclusão pautados numa situação de continuidade (Fragoso \& Florentino, 2001) ${ }^{122}$, garantiu seu sucesso ao se difundir - por meio do habitus - por diversas estruturas da sociedade, especialmente aquelas ligadas a identidade e cultura.

\footnotetext{
${ }^{121}$ Segundo Bitencourt (2008), o Código Penal brasileiro de 1890 foi elaborado "às pressas" para acompanhar a proclamação da República. Por esse motivo, apresentava baixa qualidade e era atrasado em relação às ideias de sua época (Bitencourt, 2008:45).

${ }^{122}$ Ainda que os estudos de Fragoso \& Florentino remetam até o século XVIII, é possível estender a sua leitura de "arcaísmo como projeto social" para esse período, pelo menos no que tange à questão linguística.
} 


\section{Conclusões}

O material da ENC apresentou uma alta produtividade de sentenças com sujeito pós-verbal, em descompasso com o padrão SV já incorporado pelo vernáculo, o que levou à busca de um modelo que orientasse tais produções. Com base no preceito de que a língua é também um produto de cultura, procedemos à comparação de nossos resultados com textos de escritores portugueses, brasileiros, e de membros da elite intelectual paulista, visando a identificar se algum deles era tomado como parâmetro.

A realização da ordem nas cartas de escritores portugueses mostrou uma surpreendente proximidade com a de escritores brasileiros da mesma época, eliminando a hipótese de que o padrão culto paulista, que manifestava um alto índice de sujeito posposto, tinha sua fonte do outro lado do Attântico. Igualmente, a ENC não se pautava nos escritores brasileiros selecionados, mais próximos do vernáculo do que da modalidade culta no que se refere à estruturação da ordem sentencial.

Excluídos os romancistas como referencial linguístico, nos voltamos para os paulistas Eduardo Prado e Pereira Barreto. Apesar de também apresentarem diferença em relação aos resultados da ENC, a realização da ordem por esses autores é a que mais se assemelha ao padrão da Escola. É preciso lembrar que havia um núcleo comum de sujeitos ligados às instituições intelectuais paulistas. Representando a intelectualidade local emergente, veiculavam uma cultura bacharelesca originada na Academia, principal fonte geradora de dirigentes e professores da ENC, não fugindo à sua vocação.

De fato, a ADSP tinha entre seus objetivos iniciais a formação de quadros para a burocracia estatal (Adorno, 1988:235), necessidade originada com a Independência era preciso que os cargos públicos fossem assumidos por nacionais - e intensificada ao longo do século XIX com o surgimento e consolidação de instituições burocráticas. Já no século XX, entre 1937 e 1943, essa função era ainda notável, conforme registra 
Candido (2004) sobre sua experiência na Academia. A faculdade "sentia uma espécie de obrigação de produzir políticos, funcionários, intelectuais e até figuras de ornamento, como então ainda se necessitava" (Candido, 2004: 251-252).

A influência da Academia sobre a Escola Normal, entre outros exemplos, se faz notar claramente, entre outros exemplos, no currículo de língua portuguesa do $2^{\circ}$ ano do Curso Normal, manifestada no exercício de escrita de requerimentos, ofícios e cartas, como consta do programa para o ano de 1895, evidenciando a existência de uma intersecção entre esses núcleos culturais.

No que se refere às realizações da ordem de constituintes no corpus deste estudo, entendemos que o afastamento do vernáculo representa o diferencial entre o vulgar (SV) e o distinto (VS), bem como a filiação a uma cultura conservadora pautada em padrões vinculados ao passado.

Além do conservadorismo, outra marca essencial da ADSP foi a capacidade de, pela conformação de valores e costumes, criar um grupo com características comuns. Essa particularidade é notada por Candido (2004) em sua experiência e a partir da leitura das memórias de um ex-aluno da São Francisco, do século XIX:

Quem lê os volumes de Almeida Nogueira sobre a Faculdade de Direito de São Paulo, a "Academia”, como era chamada, tem por vezes a impressão de que ela era uma espécie de grêmio. Para ser admitido era preciso adotar certos hábitos, escolher uns tantos padrões de convivência, optar por duas ou três modalidades políticas permitidas. No fim, por cima das diferenças e das divergências, todos saíam com o sentimento de que a terra lhes pertencia de certo modo e eles eram a sua melhor pitada de sal. O recrutamento não era de todo exclusivo, porque 
não abrangia apenas os filhos de fazendeiros, comerciantes, políticos ou bachareis, embora a maioria correspondesse a este requisito. Mas havia um pressuposto tácito: quem entrava, fosse qual fosse a origem, devia conformar-se aos traços essenciais das classes dominantes e sair como se em princípio fizesse parte delas ou estivesse adaptado a elas. A Academia de Almeida Nogueira parece uma poderosa máquina de fabricar, manter e, se necessário, transformar elites. (Op. cit.: 251-252, grifo nosso)

Essas observações mostram uma importante face da Academia de Direito: a de centro formador de habitus. Essa propriedade se projetava na ENC pela presença de sujeitos preparados conforme a cultura bacharelesca e que a traziam para a instituição normalista. Essa cultura, marcadamente masculina, reproduzia no ambiente da Escola uma divisão de papeis à semelhança da divisão familiar: assim como ao pai cabia a administração do lar e, à mãe, a educação dos filhos, os homens arrogavam para si o papel de administradores e professores da ENC, restringindo às mulheres o espaço da Escola Modelo e dos grupos escolares que então proliferavam, o que justifica o aumento de alunas normalistas ocorrido na virada do século.

Apesar da distinção hierárquica dos postos femininos e masculinos no ensino público, a partir desse momento as mulheres assumem maior repercussão cultural e linguística conferida pela magistério e possivelmente marcada pela reprodução do habitus linguístico originado na Academia, o qual se manifestava, entre outras características, na ordem VS. Assumiam, assim, maior expressividade social, fato que incita novos estudos sobre a formação do padrão culto na modalidade escrita do português paulista nos anos iniciais do século XX. 


\section{Fontes Documentais}

\section{Escola Normal}

CENTRO DE REFERÊNCIA EM EDUCAÇÃO MÁRIO COVAS

Acervo da Escola Caetano de Campos

Atas da Congregação da Escola Normal da Capital, 1895.

Correspondência Oficial da Escola Normal da Capital, 1894.

Livro de Ponto, 1894-1895.

Registro de Diplomas de Habilitação - Escola Normal da Capital, 1888, 1894-1899.

Termos de Matrículas - Escola Normal da Capital, 1888-1899.

\section{Cartas}

ASSIS, Machado de (1994). Obra Completa, vol. III. Rio de Janeiro: Nova Aguilar.

AZEVEDO, Manuel Antonio Álvares de (1976). Cartas de Álvares de Azevedo. Biblioteca Academia Paulista de Letras, vol. I. São Paulo: Academia Paulista de Letras.

BRANCO, Camillo Castello (1895). Cartas de Camillo Castello Branco. Lisboa: Tavares Cardoso e Irmão.

CUNHA, Euclides da. Correspondência. Disponível em http://www.culturabrasil.org/ correspondencia.htm. Acesso em 12/05/2010.

QUEIROZ, José Maria Eça de \& MARTINS, Joaquim Pedro de Oliveira (1995). Correspondência. Campinas, SP: EdUnicamp. 


\section{Referências Bibliográficas}

AULETE, Francisco Julio de Caldas (1866). Syntaxe. In: Grammatica Nacional Elementar. Lisboa: Imprensa Nacional.

BAUAB, Maria Aparecida Rocha (1972). O ensino normal na Província de São Paulo: 1846-1889. Doutoramento em Filosofia. Faculdade de Filosofia, Ciências e Letras de São José do Rio Preto.

BERLINCK, Rosane de Andrade (1989). "A construção V SN no português do Brasil: uma visão diacrônica do fenômeno da ordem”. In: Fernando Tarallo (org.). Fotografias sociolingüísticas. Campinas: Pontes: Editora da Universidade Estadual de Campinas, p. 95-112.

BERLINCK, Rosane de A.; AUGUSTO, Marina R. A. \& SCHER, Ana Paula (2001). Sintaxe. In: MUSSALIM, Fernanda \& BENTES, Anna Christina (orgs.). Introdução à lingüística. SP: Cortez.

BERLINCK, Rosane de A.; DUARTE, Maria Eugênia \& OLIVEIRA, Marilza de (2009). Predicação. In: KATO, Mary \& NASCIMENTO, Milton do. Gramática do Português Culto Falado no Brasil. Vol. III. Campinas: Ed.Unicamp.

BITENCOURT, Cezar Roberto (2008). Tratado de Direito Penal. Parte Geral 1. 13 ${ }^{\mathrm{a}}$ edição. SP: Saraiva.

BONNEWITZ, Patrice (2005). Primeiras lições sobre a sociologia de P. Bourdieu. 2a ed. Petrópolis, RJ: Vozes.

BOURDIEU, Pierre (2008). A economia das trocas linguísticas. $2^{\mathrm{a} e d . ~ S a ̃ o ~ P a u l o: ~}$ Edusp. (2009). A economia das trocas simbólicas. 6 $6^{\mathrm{a}}$ ed. São Paulo: Perspectiva. 
BRITTO, Helena (1998). Deslocamento à esquerda, resumptivo-sujeito, ordem SV e a codificação sintática de juízos categórico e tético no português do Brasil. Dissertação de mestrado. Campinas: Unicamp/IEL.

BURKE, Peter (2005). Língua e identidade no início da Itália moderna. In: A arte da conversação. SP: EdUnesp.

CANDIDO, Antonio (1951). The Brazilian Family. In: Brazil, Portrait of a Continent. New York: Dryden Press. (1988). Radicalismos. Revista Estudos Avançados, 4 (8). (2004). Nas arcadas. In: Recortes. $3^{\mathrm{a}}$ ed. RJ: Ouro sobre azul, p.251-255.

CANTUARIA, Adriana Lech (2004). Das escolas de imigrantes aos colégios internacionais: a constituição do espaço das escolas internacionais em São Paulo (18781978). In: Pro-posições, v. 15, n. 2, p. 39-59.

CARVALHO, José Murilo de (2007). A formação das almas: o imaginário da República no Brasil. SP: Cia. das Letras.

CHOMSKY, Noam (1986). Knowledge of language: its nature, origin and use. New York, Praeger.

COSTA, Angela M. \& SCHWARCZ, Lilia M. (2007). 1890-1914. No tempo das certezas. SP: Cia das Letras.

FRAGOSO, João \& FLORENTINO, Manolo (2001). O arcaísmo como projeto. RJ: Civilização Brasileira.

FREHSE, Fraya (2005). O tempo das ruas: na São Paulo de fins do Império. SP: Edusp. 
HILSDORF, Maria Lúcia Spedo (2003). História da Educação Brasileira: leituras. SP: Thomson Pioneira.

HOMEM, Maria Cecília Naclério (1996). O palacete paulistano e outras formas urbanas de morar da elite cafeeira (1867-1918). São Paulo: Martins Fontes.

KATO, Mary Aizawa (1999). Aquisição e aprendizagem da língua materna: de um saber inconsciente para um saber metalinguístico. In: CABRAL, Loni Grimm \& MORAIS, José. Investigando a linguagem: ensaios em homenagem a Leonor ScliarCabral. Florianópolis: Editora Mulheres, p. 201-226.

(2000). A restrição de monoargumentalidade da ordem VS no Português do Brasil. Fórum Lingüístico, 2, 1, 97-127. Florianópolis.

LACERDA, Lilian de (2003). Álbum de leitura - Memórias de vida, histórias de leitoras. SP: EdUnesp.

MARCÍllO, Maria Luiza. (2005). História da Escola em São Paulo e no Brasil. SP: Imprensa Oficial do Estado de São Paulo - Instituto Fernand Braudel.

MARTINS, Ana Luiza (1990). Gabinetes de Leitura na Província de São Paulo: a pluralidade de um espaço esquecido. Dissertação de Mestrado. São Paulo, FFLCH/USP.

MIOTO, Carlos et alii. (2007). Novo Manual de Sintaxe. Florianópolis: Insular.

MONARCHA, Carlos. (1999). Escola Normal da Praça: o lado escuro das luzes. Campinas: Editora da UNICAMP.

NASCIMENTO, Maria Isabel M. et alii (orgs.) (2007). Instituições Escolares no Brasil: conceito e reconstrução histórica. Campinas, SP: Autores Associados.

OLIVEIRA, Marilza de (2008). Modelos Disciplinares e Padronização Lingüística. I Encontro Internacional do Projeto Processos Urbanos, UFRJ, mimeo. 
OLIVEIRA, Marilza de et alii (2009). Perfil das escolas: fins do século XIX e início do XX. In: AGUILERA, Vanderci (org.). Para a História do Português Brasileiro. Londrina: Eduel.

OLIVEIRA, Marilza de et alii. Um monarquista e um republicano na arena linguística. In: ROSAE - I Congresso Internacional de Linguística Histórica. Salvador. Publicação em livro digital, no prelo.

ORTIZ, Renato (org.) (2003). A sociologia de Pierre Bourdieu. SP: Olho d'água.

PAGOTTO, Emílio. (1998). Norma e condescendência - ciência e pureza. In: Língua e Instrumentos Linguísticos 2, 49-68.

PEROSA, Graziela Serroni (2004). Grupos familiares, investimentos educacionais e o mercado escolar de São Paulo em 1930. In: Pro-posições v. 15, nº 2, p. 61-76.

PILATTI, Eloísa N. S. (2006). Aspectos sintáticos e semânticos das orações com ordem verbo-sujeito no português do Brasil. Tese de doutorado. Brasília, DF: UnB.

PIRES, Mário Jorge (2006). Sobrados e barões da velha São Paulo. São Paulo: Manole.

PONTES, Eunice. (1987). O tópico no Português do Brasil. Campinas: Pontes.

RIBEIRO, Ilza (2001). Sobre a perda da inversão no sujeito no português brasileiro. In: Para a História do Português Brasileiro. Vol. II, Tomo I - Primeiros estudos, p.91-126.

RIBEIRO, João (1979). A Língua Nacional e outros estudos linguísticos. Petrópolis: Vozes.

ROCCO, Salvador et alli.(1946). Poliantéia comemorativa 1846-1946: $1^{\circ}$ Centenário do Ensino Normal de São Paulo. SP: Graphica Brescia. 
ROCHA, Maria Aparecida dos Santos (1999). Escola Normal Caetano de Campos: inventário de fontes. São Paulo: Unesp, Campinas: Unicamp.

RODRIGUES, João Lourenço (1930). Um retrospecto: alguns subsídios para a história pragmática do ensino público em São Paulo. São Paulo: Instituto D. Anna Rosa.

SCHER, Ana Paula (2003). Quais as propriedades lexicais de uma construção com verbo leve? In: Müller, A.L.; Negrão, E.V.; Foltran, M.J. (orgs.). Semântica Formal. SP: Contexto, p. 205-219.

SCHWARCZ, Lilia Moritz (2007). O espetáculo das raças. SP: Cia das Letras.

SPANO, Maria (2002). A ordem V SN em construções monoargumentais. Dissertação de mestrado. Rio de Janeiro: UFRJ/LETRAS.

(2009). A ordem Verbo-Sujeito no Português Brasileiro e Europeu: um estudo sincrônico da escrita padrão. Tese de doutorado. Rio de Janeiro: UFRJ/LETRAS.

STEFANI, Celia Regina Baider (2007). O sistema ferroviário paulista - um estudo sobre a evolução do transporte de passageiros sobre trilhos. Dissertação de mestrado. FFLCH/USP, Departamento de Geografia.

TANURI, Leonor Maria (1979). O ensino normal no estado de São Paulo: 1890-1930. São Paulo. Faculdade de Educação da USP.

TARALLO, Fernando (1993). Diagnosticando uma gramática brasileira: o português d'aquém e d'além-mar ao final do século XIX. In: ROBERTS, Ian \& KATO, Mary (orgs.). Português Brasileiro: uma viagem diacrônica. Campinas, SP: Ed.Unicamp.

TARALLO, Fernando \& KATO, Mary (2006). Harmonia trans-sistêmica: variação intra- e inter-linguística. In: Diadorim: Revista de Estudos Linguísticos e Literários. - n. 1. RJ: UFRJ, Programa de Pós-Graduação em Letras Vernáculas, p.13-42. 
TORRES MORAIS, Maria Aparecida (2003). Aspectos diacrônicos do movimento do verbo, estrutura da frase e caso nominativo no português do Brasil. In: ROBERTS, Ian \& KATO, Mary (orgs.). Português brasileiro: uma viagem diacrônica. Campinas: Ed. Unicamp, p. 263-306.

TRIGO, Maria Helena Bueno (1989). Ser e parecer: estudo sobre as práticas de reprodução social do grupo cafeicultor paulista. Dissertação de Mestrado. FFLCH/USP.

VENOSA, Sílvio de Salvo (2004). Codificação e técnicas legislativas. Introdução ao Estudo do Direito. SP: Atlas, p.219-238.

VERÍSSIMO, José (1969). "Briga de Gramáticos". In: Obras Completas de Rui Barbosa. Anexos à Réplica. Vol. 29, Tomo 4. Rio de Janeiro, MEC, p.113-119.

VIOTTI, Evani (2007). Revisitando a ordem do português brasileiro: questionando a existência de expletivos nulos. In: CASTILHO, Ataliba et alli. (orgs.) Descrição, História e Aquisição do Português Brasileiro. Campinas: Pontes Editores.

VOTRE, Sebastião \& CEZARIO, Maria Maura (1996). Gramaticalização na ordenação vocabular de sujeito e auxiliar-verbo. In: MARTELLOTA, Mário E. et alli. Gramaticalização no Português do Brasil: uma abordagem funcional. RJ: Tempo Brasileiro. 